In cooperation with the Oklahoma Water Resources Board

\title{
Water Use in Oklahoma 1950-2005
}
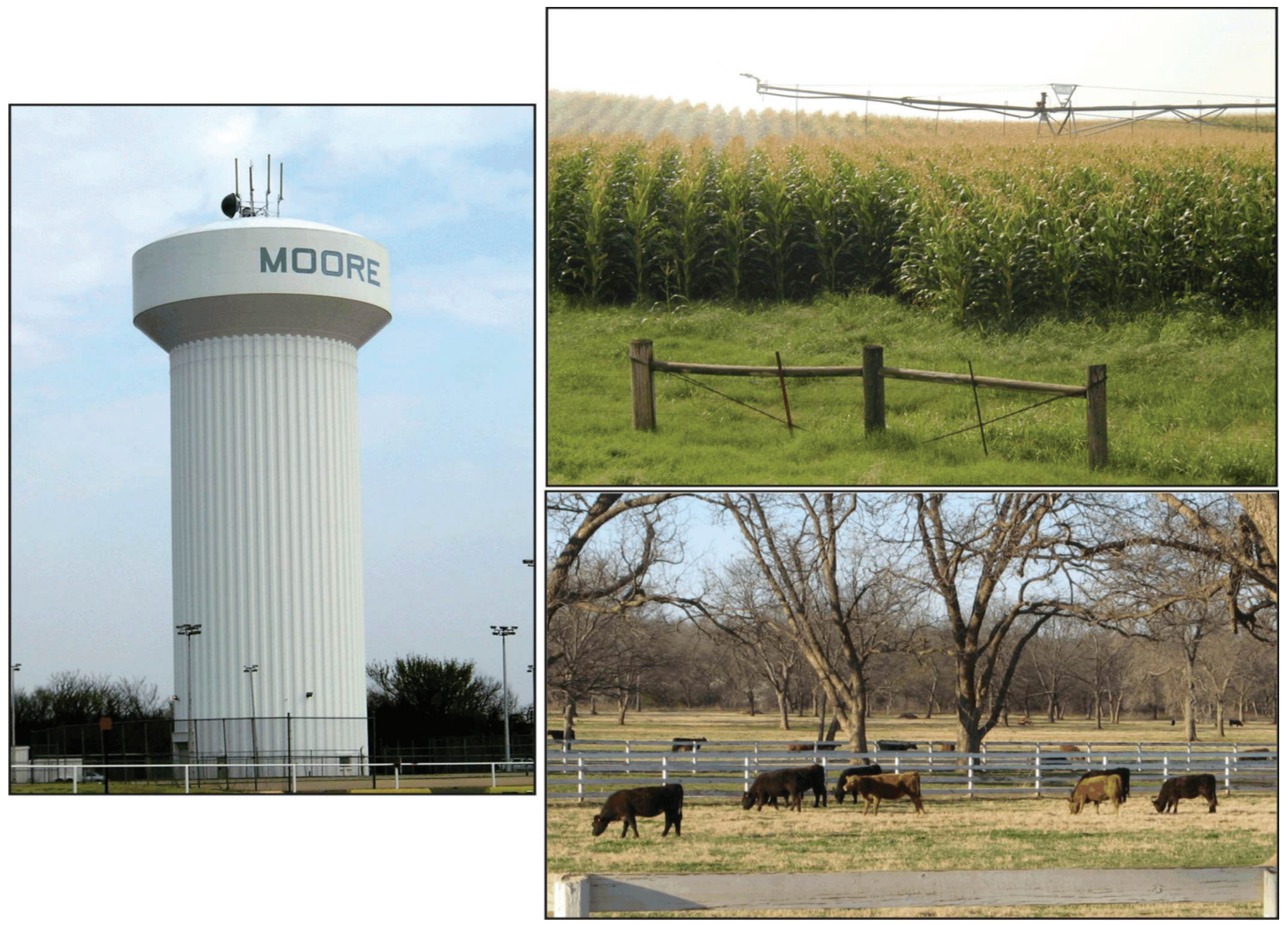

\section{Scientific Investigations Report 2009-5212}




\section{Cover Credits:}

Left photograph shows public supply water tower for Moore, Cleveland County, Oklahoma, taken March 2009 by Robert Tortorelli, U.S. Geological Survey.

Upper right photograph shows center-pivot irrigation of field corn near Ringwood, Major County, Oklahoma, taken July 2003 by S. Jerrod Smith, U.S. Geological Survey.

Lower right photograph shows cattle, 3-Sisters Ranch, Pottawatomie County, Oklahoma, taken March 2009 by Jason Masoner, U.S. Geological Survey. 


\section{Water Use in Oklahoma 1950-2005}

By Robert L. Tortorelli

Prepared in cooperation with the Oklahoma Water Resources Board

Scientific Investigations Report 2009-5212 


\title{
U.S. Department of the Interior \\ KEN SALAZAR, Secretary \\ U.S. Geological Survey \\ Marcia K. McNutt, Director
}

\section{U.S. Geological Survey, Reston, Virginia: 2009}

\author{
For more information on the USGS — the Federal source for science about the Earth, its natural and living resources, \\ natural hazards, and the environment, visit http://www.usgs.gov or call 1-888-ASK-USGS \\ For an overview of USGS information products, including maps, imagery, and publications, \\ visit http://www.usgs.gov/pubprod \\ To order this and other USGS information products, visit http://store.usgs.gov
}

\begin{abstract}
Any use of trade, product, or firm names is for descriptive purposes only and does not imply endorsement by the U.S. Government.

Although this report is in the public domain, permission must be secured from the individual copyright owners to reproduce any copyrighted materials contained within this report.
\end{abstract}

Suggested citation:

Tortorelli, R.L., 2009, Water Use in Oklahoma 1950-2005: U.S. Geological Survey Scientific Investigations Report 2009-5212, $49 \mathrm{p}$. 


\section{Contents}

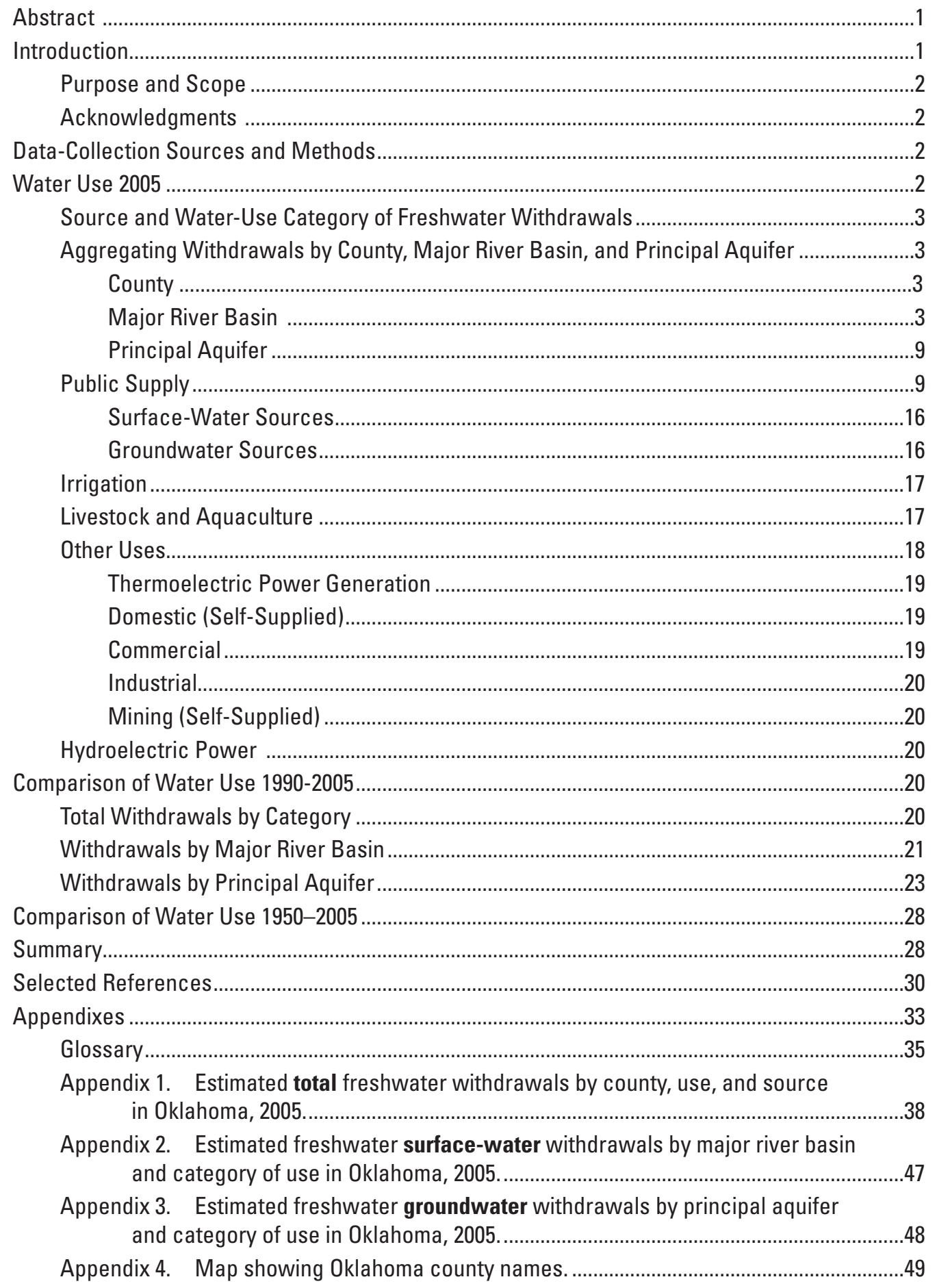




\section{Figures}

1-2. Pie charts showing:

1. Freshwater withdrawals by major category and source in Oklahoma, 2005...................4

2. Freshwater withdrawals by source and major category in Oklahoma, 2005....................5

3-4. Pipe diagrams showing:

3. Source and use category of freshwater withdrawals in Oklahoma, 2005. ......................6

4. Source and delivery category of freshwater public-supply withdrawals in Oklahoma, 2005.

5-11. Maps showing:

5. Freshwater withdrawals by major category and county in Oklahoma, 2005.

6. Freshwater withdrawals by percentage source and county in Oklahoma, 2005............10

7. Surface-water withdrawals by major category and county in Oklahoma, 2005..............11

8. Selected municipalities and water sources in Oklahoma, 2005 ...................................12

9. Groundwater withdrawals by major category and county in Oklahoma, 2005 ..............13

10. Surface-water withdrawals by major river basin and category in Oklahoma, 2005.......14

11. Groundwater withdrawals by principal aquifer and category in Oklahoma, 2005.........15

12-18. Bar charts showing:

12. (A) Public supply withdrawals by source in Oklahoma, 1990-2005 (B) Population by source of water in Oklahoma, 1990-2005

13. (A) Irrigation withdrawals by source in Oklahoma, 1990-2005 (B) Irrigated acres by application method in Oklahoma, 1990-2005.

14. (A) Livestock and aquaculture withdrawals by source in Oklahoma, 1990-2005

(B) Other water self-supplied by category in Oklahoma, 1990-2005.

15. (A) Public supply surface-water withdrawals by major river basin in Oklahoma, 19902005 (B) Irrigation surface-water withdrawals by major river basin in Oklahoma, 19902005 (C) Livestock and aquaculture surface-water withdrawals by major river basin in Oklahoma, 1990-2005.

16. (A) Public supply groundwater withdrawals by principal aquifer in Oklahoma, 19902005 (B) Irrigation groundwater withdrawals by principal aquifer in Oklahoma, 19902005 (C) Livestock and aquaculture groundwater withdrawals by principal aquifer in Oklahoma, 1990-2005.

17. Freshwater withdrawals by source and population in Oklahoma, 1950-2005 ................29

18. Freshwater withdrawals by category in Oklahoma, 1950-2005. .29

\section{Tables}

1. Estimated surface-water, groundwater, and total freshwater withdrawals for top 10 counties in Oklahoma, 2005.

2. Estimated surface-water, groundwater, and total public supply freshwater withdrawals for top 10 counties in Oklahoma, 2005.

3. Estimated surface-water, groundwater, and total irrigation freshwater withdrawals for top 10 counties in Oklahoma, 2005.

4. Estimated surface-water, groundwater, and total livestock and aquaculture freshwater withdrawals for top 10 counties in Oklahoma, 2005.

5. Estimated freshwater surface-water use and power generated by hydroelectric power by county and major river basin in Oklahoma, 2005. 


\section{Conversion Factors}

\begin{tabular}{lcl}
\hline \multicolumn{1}{c}{ Multiply } & \multicolumn{1}{c}{ By } & \multicolumn{1}{c}{ To obtain } \\
\hline mile (mi) & \multicolumn{1}{c}{ Length } & kilometer $(\mathrm{km})$ \\
\hline & \multicolumn{1}{c}{ Area } & \\
acre & 0.4047 & hectare $(\mathrm{ha})$ \\
\hline & \multicolumn{1}{c}{ Volume } & \\
gallon (gal) & 3.785 & liter $(\mathrm{L})$ \\
gallon (gal) & 0.003785 & cubic meter $\left(\mathrm{m}^{3}\right)$ \\
million gallons (Mgal) & 3,785 & cubic meter $\left(\mathrm{m}^{3}\right)$ \\
acre-foot (acre-ft) & 1,233 & cubic meter $\left(\mathrm{m}^{3}\right)$ \\
acre-foot (acre-ft) & 0.001233 & cubic hectometer $\left(\mathrm{hm}^{3}\right)$ \\
\hline & \multicolumn{1}{c}{ Flow rate } & \\
\hline acre-foot per day (acre-ft/d) & 0.01427 & cubic meter per second $\left(\mathrm{m}^{3} / \mathrm{s}\right)$ \\
foot per second $(\mathrm{ft} / \mathrm{s})$ & 0.3048 & meter per second $(\mathrm{m} / \mathrm{s})$ \\
cubic foot per second (ft/ $/ \mathrm{s})$ & 0.02832 & cubic meter per second $\left(\mathrm{m}^{3} / \mathrm{s}\right)$ \\
gallon per minute $(\mathrm{gal} / \mathrm{min})$ & 0.06309 & liter per second $(\mathrm{L} / \mathrm{s})$ \\
gallon per day (gal/d) & 0.003785 & cubic meter per day $\left(\mathrm{m}^{3} / \mathrm{d}\right)$ \\
million gallons per day $(\mathrm{Mgal} / \mathrm{d})$ & 0.04381 & cubic meter per second $\left(\mathrm{m}^{3} / \mathrm{s}\right)$ \\
\hline
\end{tabular}

Vertical coordinate information is referenced to the North American Vertical Datum of 1988 (NAVD 88).

Horizontal coordinate information is referenced to the North American Datum of 1983 (NAD 83). 


\title{
Water Use in Oklahoma 1950-2005
}

\author{
By Robert L. Tortorelli
}

\section{Abstract}

Comprehensive planning for water resources development and use in Oklahoma requires a historical perspective on water resources. The U.S. Geological Survey, in cooperation with the Oklahoma Water Resources Board, summarized the 1950-2005 water-use information for Oklahoma. This report presents 1950-2005 estimates of freshwater withdrawal for water use in Oklahoma by source and category in 5-year intervals. Withdrawal source was either surface water or groundwater. Withdrawal categories include: public supply, irrigation, livestock and aquaculture, thermoelectric-power generation (cooling water), domestic and commercial, and industrial and mining. Withdrawal data were aggregated and tabulated by county, major river basin, and principal aquifer.

The purpose of this report is to summarize water-use data in Oklahoma through: (1) presentation of detailed information on freshwater withdrawals by source, county, major river basin, and principal aquifer for 2005; (2) comparison of water use by source, category, major river basin, and principal aquifer at 5-year intervals from 1990-2005; and (3) comparison of water use on a statewide basis by source and category at 5-year intervals from 1950-2005.

Total withdrawals from surface-water and groundwater sources during 2005 were 1,559 million gallons per day-989 million gallons a day or 63 percent from surface-water sources and 570 million gallons per day or 37 percent from groundwater sources. The three largest water use categories were: public supply, 646 million gallons per day or 41 percent of total withdrawals; irrigation, 495 million gallons per day or 32 percent of total withdrawals; and livestock and aquaculture, 181 million gallons per day or 12 percent of total withdrawals. All other categories were 237 million gallons per day or 15 percent of total withdrawals.

The influence of public supply on the total withdrawals can be seen in the eastern two-thirds of Oklahoma; whereas, the influence of irrigation on total withdrawals can be seen in the western third of Oklahoma. Surface-water sources were dominant in the eastern half of Oklahoma and groundwater sources were dominant in the western half of Oklahoma.

Public supply withdrawals increased steadily from 19902000 and then decreased slightly in 2005, mainly because of a decrease in surface-water withdrawals. Irrigation withdrawals increased from 1990-1995 and then decreased steadily to
2005. Total livestock and aquaculture withdrawals steadily increased from 1990-2005. The largest increase in the other categories was for thermoelectric power generation that has steadily increased and almost doubled from 1990-2005.

Surface-water sources have been increasing in importance from 1950-2005, in part because of the increasing percentage of surface-water for public supply as the total population of Oklahoma and population served by surface-water sources increased. Groundwater sources have been generally decreasing in importance as a percentage of total withdrawals in recent years. However, the magnitude of groundwater withdrawals was greatly dependent on irrigation withdrawals and specifically irrigated acreage in the panhandle.

\section{Introduction}

Water is one of the most valuable natural resources in Oklahoma. Comprehensive planning for water-resources development and use in Oklahoma requires a historical perspective on water resources. Currently no comprehensive report of historic water use in Oklahoma exists.

The U.S. Geological Survey (USGS) has compiled national estimates by state every 5 years since 1950 . The USGS established the National Water-Use Information Program in 1977 to collect uniform and reliable information on water use (Hutson and others, 2004). These national estimates have been reported in a series of water-use reports (MacKichan, 1951, 1957; MacKichan and Kammerer, 1961; Murray, 1968; Murray and Reeves, 1972, 1977; Solley and others, 1983, 1988, 1993, 1998; Hutson and others, 2004; Kenny and others, 2009). These data can be used along with information on surface-water and groundwater availability to assess waterresource management needs as demands for water increase and change.

Water supplies and water uses in the United States have been affected by population growth, economic trends, legal decisions, and periodic droughts since 1950 . In response to constraints on water supplies, communities have expanded water supply infrastructures or instituted water-conservation measures, farmers have changed crops or agricultural practices, and industries have reused or reclaimed process water. Population changes affecting water use during the time period from 1950-2000 include an overall population increase of 
90 percent, with a shift in the population of the United States from rural areas to urban areas and a continuing shift of the mean geographic center of population west and south (Hobbs and Stoops, 2002).

The Oklahoma Water Science Center of the USGS, in cooperation with the Oklahoma Water Resources Board (OWRB), summarized the 1950-2005 water-use information for Oklahoma. The data presented here are the result of the 1950-2005 compilation efforts for Oklahoma by the USGS.

\section{Purpose and Scope}

The purpose of this report is to summarize water-use data in Oklahoma through: (1) presentation of detailed information on freshwater withdrawals by source, county, major river basin, and principal aquifer for 2005; (2) comparison of water use by source, category, major river basin, and principal aquifer at 5-year intervals from 1990-2005; and (3) comparison of water use on a statewide basis by source and category at 5-year intervals from 1950-2005.

This report presents estimates of freshwater withdrawal for water use in Oklahoma by source and category from 19502005 in 5-year intervals. Withdrawal source was either surface water or groundwater. Withdrawal categories included: public supply, irrigation, livestock and aquaculture, thermoelectricpower generation (cooling water), domestic and commercial, and industrial and mining (glossary, back of report). Withdrawal data were aggregated and tabulated by county, major river basin, and principal aquifer.

This analysis can be used by water-resources managers in assessing the patterns of water use in Oklahoma. This report shows the major water use categories and how the water use categories have changed over time by amount and source by using 5-year intervals. Amounts of water withdrawn may vary slightly in categories and sources in tables and figures because of independent rounding.

\section{Acknowledgments}

The author thanks many people for their contributions to the data collection and data analysis presented in this report. Andy Scurlock and Brian Vance of the Oklahoma Water Resources Board provided summaries of the 2005 Water Use Reports, which are annual mail surveys. Additional special thanks go to numerous individuals in local, state and federal agencies including the City of Oklahoma City, City of Tulsa, Grand River Dam Authority, Oklahoma Municipal Power Authority, Oklahoma Pork Council, Oklahoma Corporation Commission, Oklahoma Department of Commerce, Oklahoma Department of Environmental Quality, Bureau of Reclamation, Natural Resources Conservation Service, Southwest Power Administration, U.S. Army Corps of Engineers Tulsa District, and U.S. Fish and Wildlife Service. S. Jerrod Smith and Jason Lewis of the USGS Oklahoma Water Science Center were contributors to the report.

\section{Data-Collection Sources and Methods}

Site-specific water-use data for individual water-use permits for several categories were collected and compiled annually by the OWRB by using a mail-in Water Use Report. These water-use data for the categories of public supply, irrigation, livestock and aquaculture, thermoelectric-power generation, domestic and commercial, and industrial and mining are available in a database at the OWRB. The individual water-use reports show estimates of the annual amount of water withdrawn and source (surface water or groundwater). The OWRB also requests information on monthly use and the amount of water sold and purchased for public supply and industrial permits. These data were supplied to the USGS for each category aggregated by county, source, and river basin or aquifer.

The water-use data must be supplemented with withdrawal estimates from other data sources because of incomplete reporting. These sources include federal, state, local, and private agencies, organizations, industries, utilities, and individuals. Primary sources include City of Oklahoma City, City of Tulsa, Grand River Dam Authority, Oklahoma Municipal Power Authority, Oklahoma Pork Council, Oklahoma Corporation Commission, Oklahoma Department of Commerce, Oklahoma Department of Environmental Quality, Bureau of Reclamation, Natural Resources Conservation Service, Southwest Power Administration, U.S. Army Corps of Engineers Tulsa District, and U.S. Fish and Wildlife Service.

Additional water-use estimates were made by USGS on the basis of population and average consumption rates for water-use categories for which data were not available or incomplete such as self-supplied domestic and livestock. These data also were aggregated by county, source, and river basin or aquifer.

These data were placed in the USGS Aggregate Water Use Data System (AWUDS) (Perlman, 1998; Hutson, 2007) in the USGS Oklahoma Water Science Center for the years 1985-2005 and reviewed by USGS headquarters water-use specialists. These data are available by county on the USGS Water Use in the United States web site at http://water.usgs. gov/watuse/. Appendixes 1-3 in back of the report have water-use estimates from the 2005 Oklahoma AWUDS report tables and are reported to nearest 0.01 million gallon per day (Mgal/d); all other figures and tables in the body of the report present water-use estimates to the nearest whole number of Mgal/d. The 1990-2005 data were aggregated by the author and are presented in more detail because categories and consistency of methods are known. The 1950-2005 comparisons are more general because the earlier years had fewer reporting categories and methods of compilation may not have been consistent.

\section{Water Use 2005}

In this section a general description of the 2005 withdrawal data is followed by withdrawal data in terms of county, 
major river basin, and principal aquifer. Finally, details of withdrawal data for each water-use category are described.

\section{Source and Water-Use Category of Freshwater Withdrawals}

Total withdrawals from surface-water and groundwater sources during 2005 were about $1,559 \mathrm{Mgal} / \mathrm{d}-989 \mathrm{Mgal} / \mathrm{d}$ or 63 percent from surface-water sources and $570 \mathrm{Mgal} / \mathrm{d}$ or 37 percent from groundwater sources (fig. 1, appendixes 1-3). The three largest water use categories were public supply, about $646 \mathrm{Mgal} / \mathrm{d}$ or 41 percent of total withdrawals; irrigation, $495 \mathrm{Mgal} / \mathrm{d}$ or 32 percent of total withdrawals; and livestock and aquaculture, $181 \mathrm{Mgal} / \mathrm{d}$ or 12 percent of total withdrawals. All other categories (including thermoelectric power generation, self-supplied domestic and commercial, and industrial and mining) were $237 \mathrm{Mgal} / \mathrm{d}$ or 15 percent of total withdrawals (fig. 2, appendixes 1-3).

Most of public-supply water was withdrawn from surface-water sources in 2005. Public supply withdrawals consisted of about $532 \mathrm{Mgal} / \mathrm{d}$ or 82 percent from surfacewater sources and $114 \mathrm{Mgal} / \mathrm{d}$ or 18 percent from groundwater sources. (fig. 1, appendixes 1-3). Most of irrigation water was withdrawn from groundwater sources in 2005. Irrigation withdrawals consisted of about $361 \mathrm{Mgal}$ or 73 percent from groundwater sources and $134 \mathrm{Mgal} / \mathrm{d}$ or 27 percent from surface-water sources (figs. 1-2, appendixes 1-3). Most of livestock and aquaculture water was withdrawn from surfacewater sources in 2005. Livestock and aquaculture withdrawals consisted of about $126 \mathrm{Mgal} / \mathrm{d}$ or 70 percent from surfacewater sources and $55 \mathrm{Mgal} / \mathrm{d}$ or 30 percent from groundwater sources (figs. 1-2, appendixes 1-3).

The largest water-use category for surface-water sources was public supply, $532 \mathrm{Mgal} / \mathrm{d}$ or 54 percent of surface water withdrawn (fig. 2, appendixes 1 and 2). The largest category for groundwater sources was irrigation, $361 \mathrm{Mgal} / \mathrm{d}$ or 63 percent of groundwater withdrawn (fig. 2, appendixes 1 and 3).

Pipe diagrams are useful for an overall snapshot of water use by source and use category (figs. 3 and 4). Surface water supplies most of public supply and self-supplied livestock, aquaculture, thermoelectric cooling water, commercial, industrial, and mining uses (fig. 3). Groundwater supplies most of irrigation use and is assumed the source for all self-supplied domestic use (fig. 3). Public supply includes water delivered to domestic, commercial, industrial, and thermoelectric power generation (fig. 4). Most of these uses were supplied by surface-water sources.

\section{Aggregating Withdrawals by County, Major River Basin, and Principal Aquifer}

Freshwater withdrawal estimates for each water-use category were aggregated by county, source (surface water or groundwater), and river basin or aquifer.

\section{County}

Total freshwater withdrawals for all uses and the three major categories of use (public supply, irrigation, and livestock and aquaculture) from all sources in Oklahoma are shown by county in figure 5 (appendix 1). County names are shown on the map in appendix 4. The influence of public supply on the total withdrawals can be seen the in eastern two-thirds of Oklahoma; whereas, the influence of irrigation on total withdrawals can be seen in the western third of Oklahoma. Total withdrawals also are presented by source in ranked order for the top 10 counties in Oklahoma in table 1. The percentage of water withdrawals from surface water and groundwater by county is shown in figure 6 , which illustrates the reliance on surface-water sources in the eastern half of Oklahoma and the reliance on groundwater sources in the western half of Oklahoma.

Total withdrawals for all uses and the three major categories of use from surface-water sources in Oklahoma are shown by county in figure 7 (appendixes 1, 2, and 4). The influence of public supply on the surface-water withdrawals can be seen in the eastern two-thirds of Oklahoma corresponding to the withdrawals for the major municipal users: Tulsa, and Grand River Authority in the northeast, Oklahoma City and Norman in central, Ada and Ardmore in south-central, Oklahoma City in the southeast, and Lawton in the southwest (fig. 8). The influence of irrigation on surface-water withdrawals can be seen in the western third of Oklahoma, especially for the Altus-Lugert Irrigation District (from Lake Altus, fig. 8). The influence of aquaculture on livestock surface-water withdrawals can be seen in south-central Oklahoma (fig. 7). Total surface-water withdrawals also are presented in ranked order for the top 10 counties in Oklahoma in table 1.

Total withdrawals for all uses and the three major categories of use from groundwater sources in Oklahoma are shown by county in figure 9 (appendixes 1, 3, and 4). The influence of public supply on the groundwater withdrawals can be seen in central and western Oklahoma corresponding to the withdrawals for the major municipal users: El Reno, Mustang, Yukon, Moore and Norman in central; Enid and Ponca City in northcentral; and Woodward and Guymon in the northwest (fig. 8). The influence of irrigation on groundwater withdrawals can be seen in the western one-third of Oklahoma, especially for the panhandle counties (Cimarron, Texas, and Beaver Counties). The influence of livestock operations on groundwater withdrawals can be seen in the northwest, especially in the panhandle. Total groundwater withdrawals also are presented in ranked order for the top 10 counties in Oklahoma in table 1.

\section{Major River Basin}

Total surface-water withdrawals in 2005 for the public supply, irrigation, livestock and aquaculture, and other categories in Oklahoma are shown by major river basin in figure 10 (appendix 2). Public supply was the largest category of surface-water withdrawals in 6 of the 10 major river basins: 

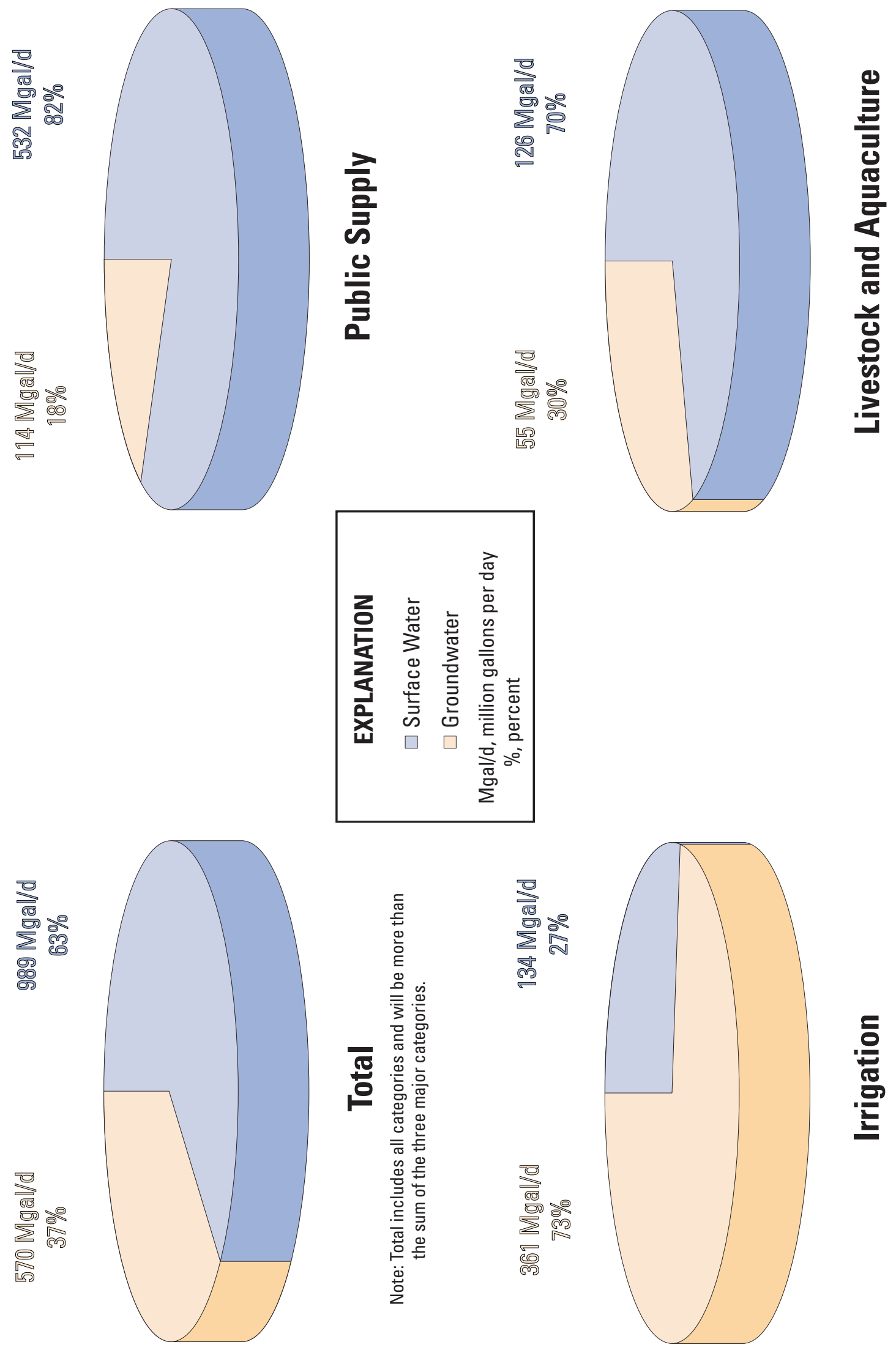

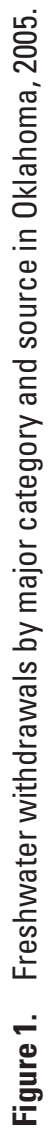



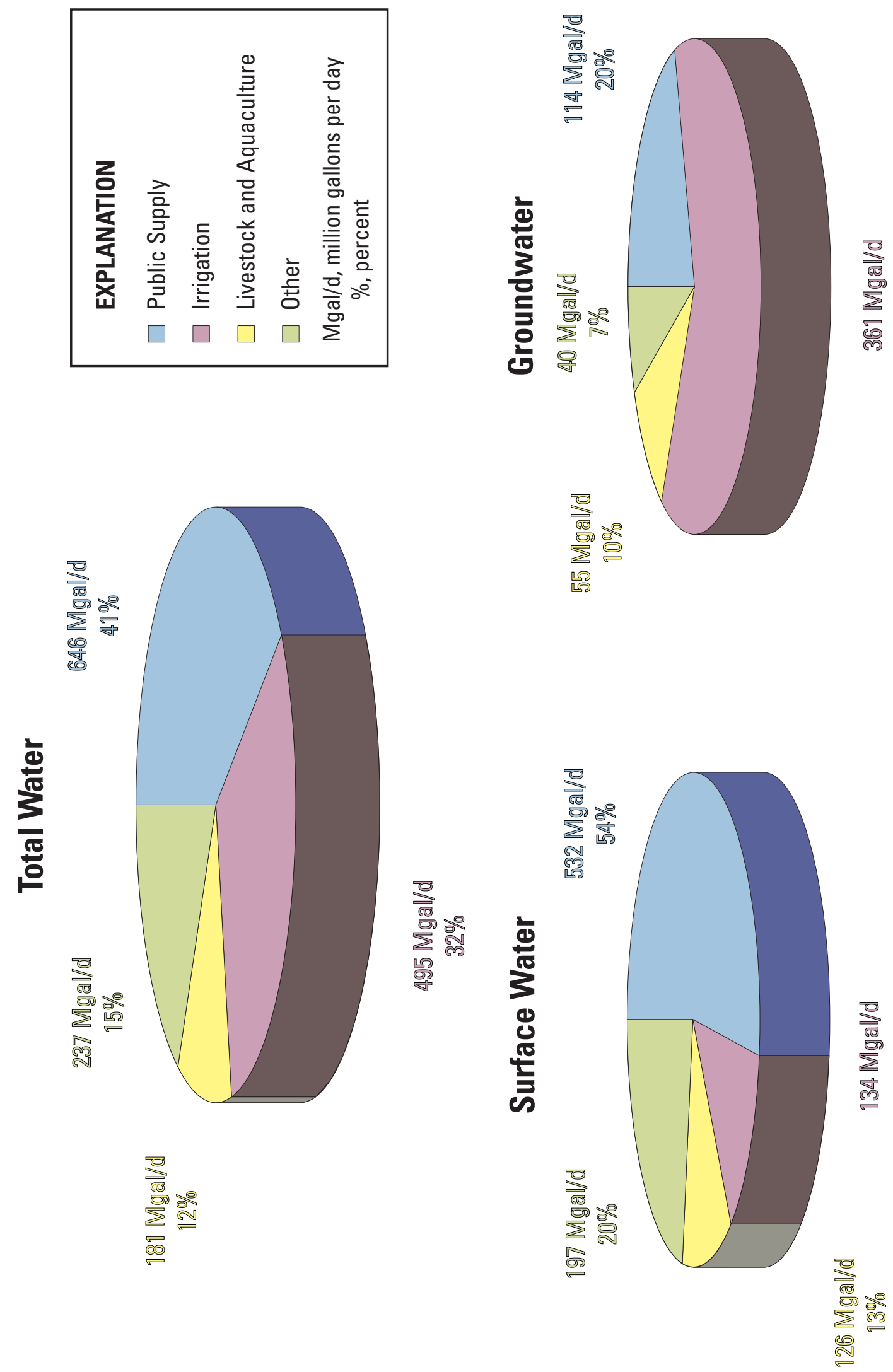


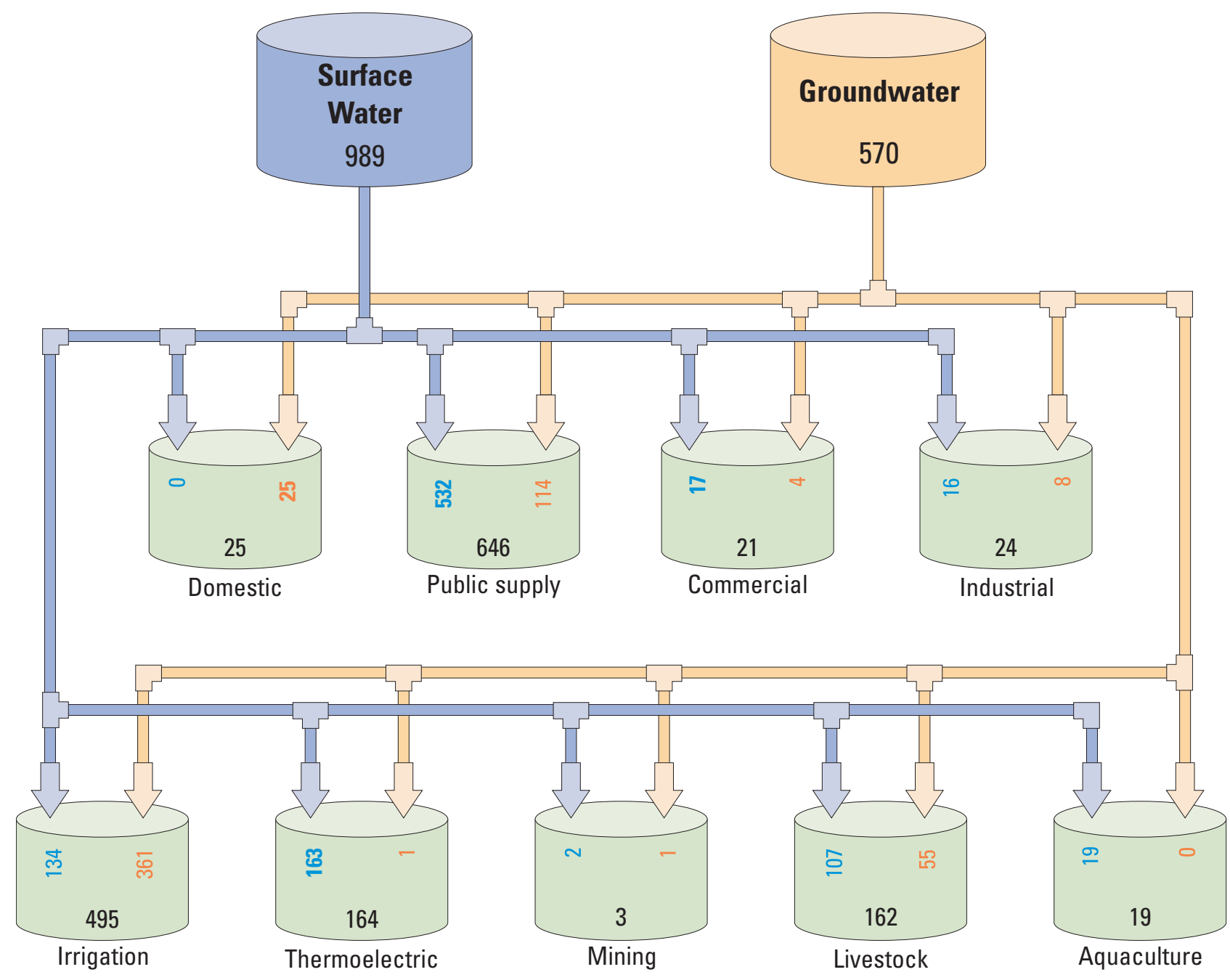

EXPLANATION

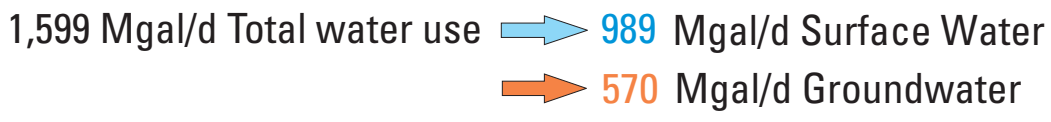

Values in million gallons per day (Mgal/d)

Source: Oklahoma Water Resources Board and various Local, State, and Federal Agencies

(Note: Data in the diagram are rounded; totals may not add to totals because of independent rounding)

Figure 3. Source and use category of freshwater withdrawals in Oklahoma, 2005. 


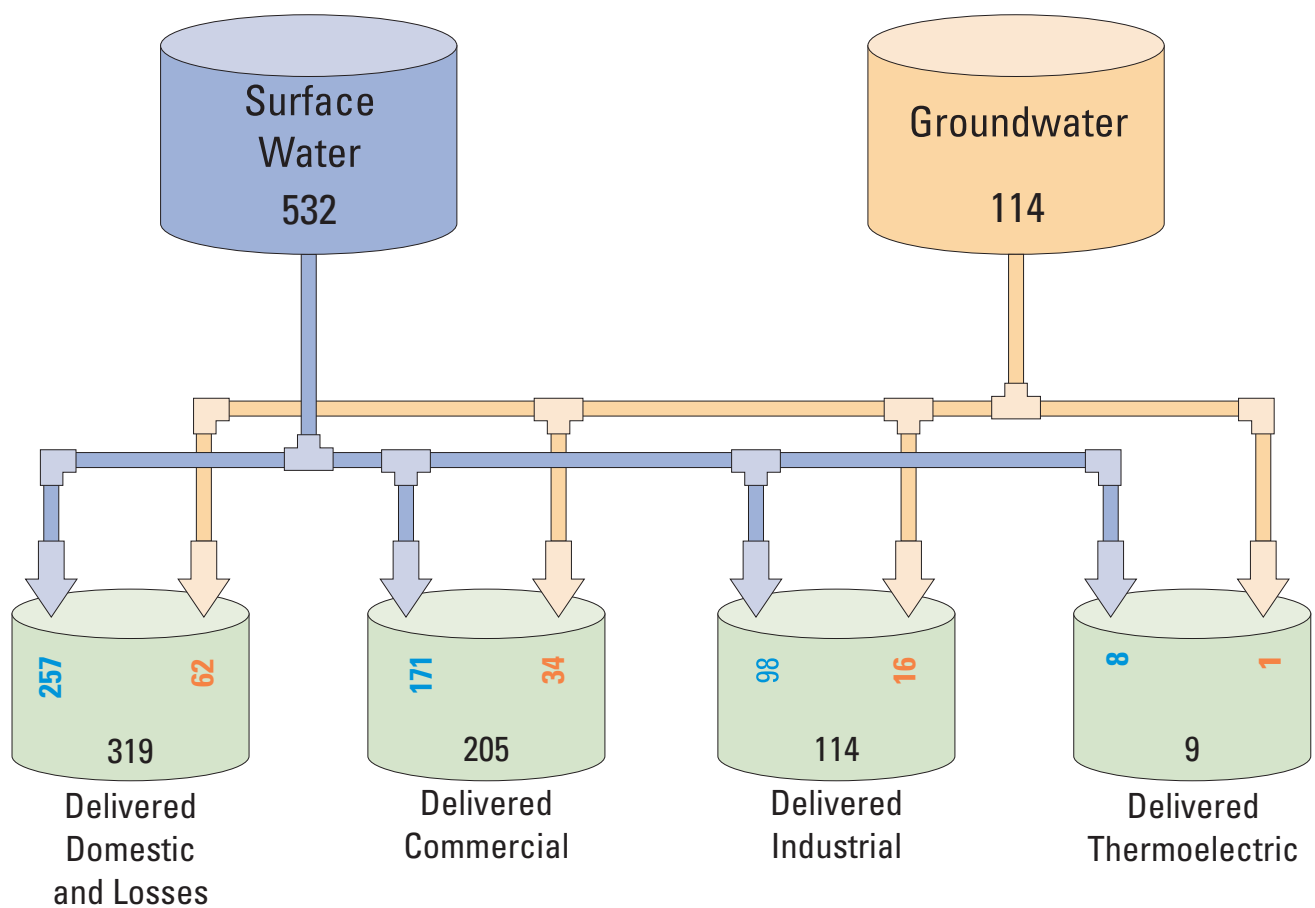

\section{EXPLANATION}

\section{$646 \mathrm{Mgal} / \mathrm{d}$ Total public supply use $\Longrightarrow 532 \mathrm{Mgal} / \mathrm{d}$ Surface water $\Rightarrow 114 \mathrm{Mgal} / \mathrm{d}$ Groundwater}

Values in million gallons per day $(\mathrm{Mgal} / \mathrm{d})$

Source: Oklahoma Water Resources Board and various Local, State, and Federal Agencies (Note: Data in the diagram are rounded; totals may not add to totals because of independent rounding)

Figure 4. Source and delivery category of freshwater public-supply withdrawals in Oklahoma, 2005. 

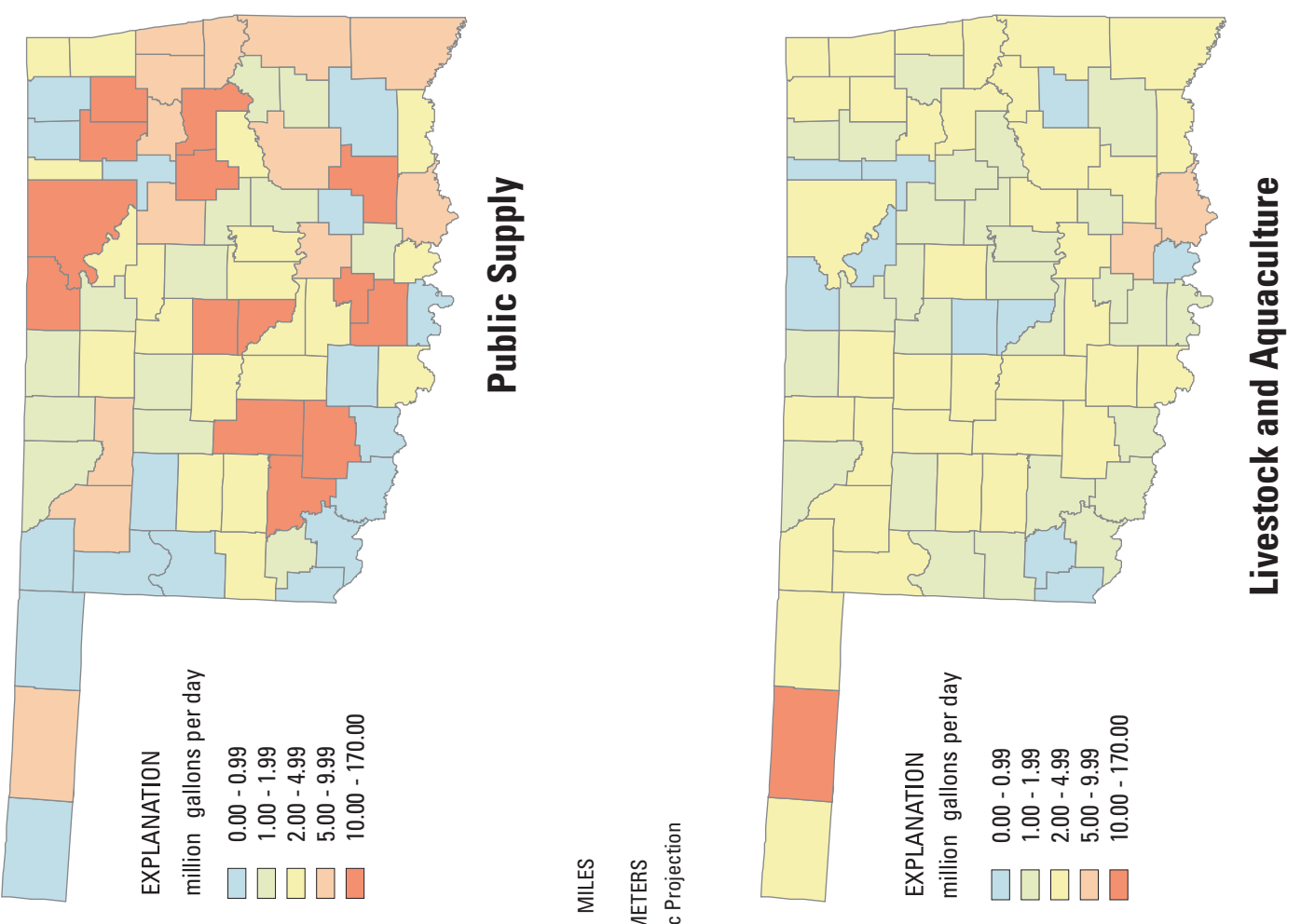

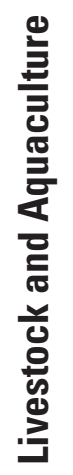

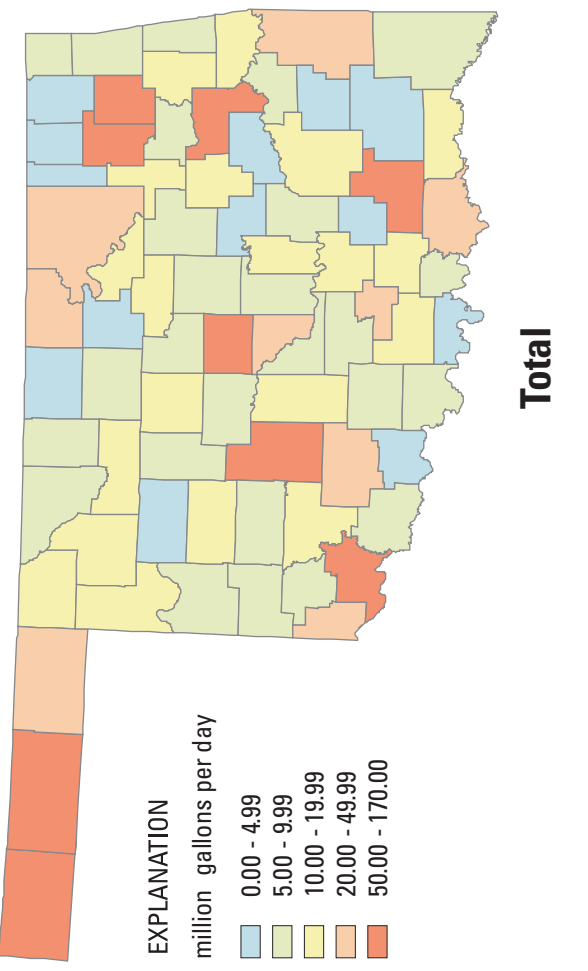

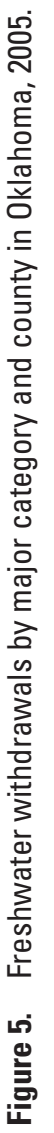


Table 1. Estimated surface-water, groundwater, and total freshwater withdrawals for top 10 counties in Oklahoma, 2005.

[Amounts are in million gallons per day. Totals may not add to totals because of independent rounding]

\begin{tabular}{|c|c|c|c|c|c|c|}
\hline Rank & County & $\begin{array}{c}\text { Total } \\
\text { surface } \\
\text { water }\end{array}$ & County & $\begin{array}{l}\text { Total } \\
\text { ground- } \\
\text { water }\end{array}$ & County & $\begin{array}{l}\text { Total } \\
\text { water }\end{array}$ \\
\hline 1 & Mayes & 107 & Texas & 167 & Texas & 167 \\
\hline 2 & Muskogee & 106 & Cimarron & 51 & Muskogee & 110 \\
\hline 3 & Oklahoma & 85 & Caddo & 29 & Mayes & 107 \\
\hline 4 & Rogers & 84 & Harmon & 26 & Oklahoma & 107 \\
\hline 5 & Jackson & 67 & Beaver & 26 & Rogers & 84 \\
\hline 6 & Atoka & 56 & Oklahoma & 22 & Jackson & 76 \\
\hline 7 & Cleveland & 22 & Major & 19 & Atoka & 56 \\
\hline 8 & Caddo & 22 & Woodward & 16 & Cimarron & 51 \\
\hline 9 & Commanche & 20 & Ellis & 15 & Caddo & 51 \\
\hline 10 & LeFlore & 19 & Cleveland & 13 & Cleveland & 35 \\
\hline
\end{tabular}

North Canadian, Arkansas-Keystone, Neosho-Verdigris, RedSulphur, Lower Canadian, and Red-Washita River basins. Irrigation was the largest category of surface-water withdrawals only in the western one-third of Oklahoma in two basins: the Upper Cimarron River Basin; and Red Headwaters River Basin, which supplies the Altus-Lugert Irrigation District (from Lake Altus, fig. 8). Livestock and aquaculture surface-water withdrawals were about one-fifth or more of the withdrawals in half of the major river basins: Lower Cimarron, Arkansas-Keystone, Red-Sulphur, Lower Canadian, and Red-Washita River basins. Cooling water withdrawals for thermoelectric power generation were the largest withdrawals in the other category in two major river basins in eastern Oklahoma: Neosho-Verdigris and Lower Arkansas River basins (appendix 2).

\section{Principal Aquifer}

Total groundwater withdrawals in 2005 for the public supply, irrigation, livestock, and other categories in Oklahoma are shown by principal aquifer in figure 11 (appendix 3). All minor aquifers are summed in the "not a principal aquifer" category. Public supply groundwater withdrawals were 30 percent or more of the withdrawals in more than half of principal aquifers: Alluvial and terrace, Central Oklahoma, Ada-Vamoosa, Ozark Plateaus, Edwards-Trinity, and Arbuckle-Simpson aquifers. Irrigation was the largest category of groundwater withdrawals for more than half of the aquifers: High Plains, alluvial and terrace, Edwards-Trinity, Not Principal, Rush Springs, and Blaine aquifers. Livestock and aquaculture groundwater withdrawals were a large volume of withdrawals in the northwest from two aquifers, High Plains and alluvial and terrace aquifers, relative to the other aquifers (appendix 3).

\section{Public Supply}

Public-supply systems served about 3.2 million people or about 92 percent of the population in Oklahoma in 2005 (appendix 1). Surface-water withdrawals for public supply served about 2.5 million people or 71 percent of the population in 2005. Groundwater withdrawals for public supply served about 725,000 people or 20 percent of the population in 2005. Most of public-supply water was withdrawn from surface-water sources. Public supply had about $532 \mathrm{Mgal} / \mathrm{d}$ or 82 percent withdrawn from surface-water sources and 114 


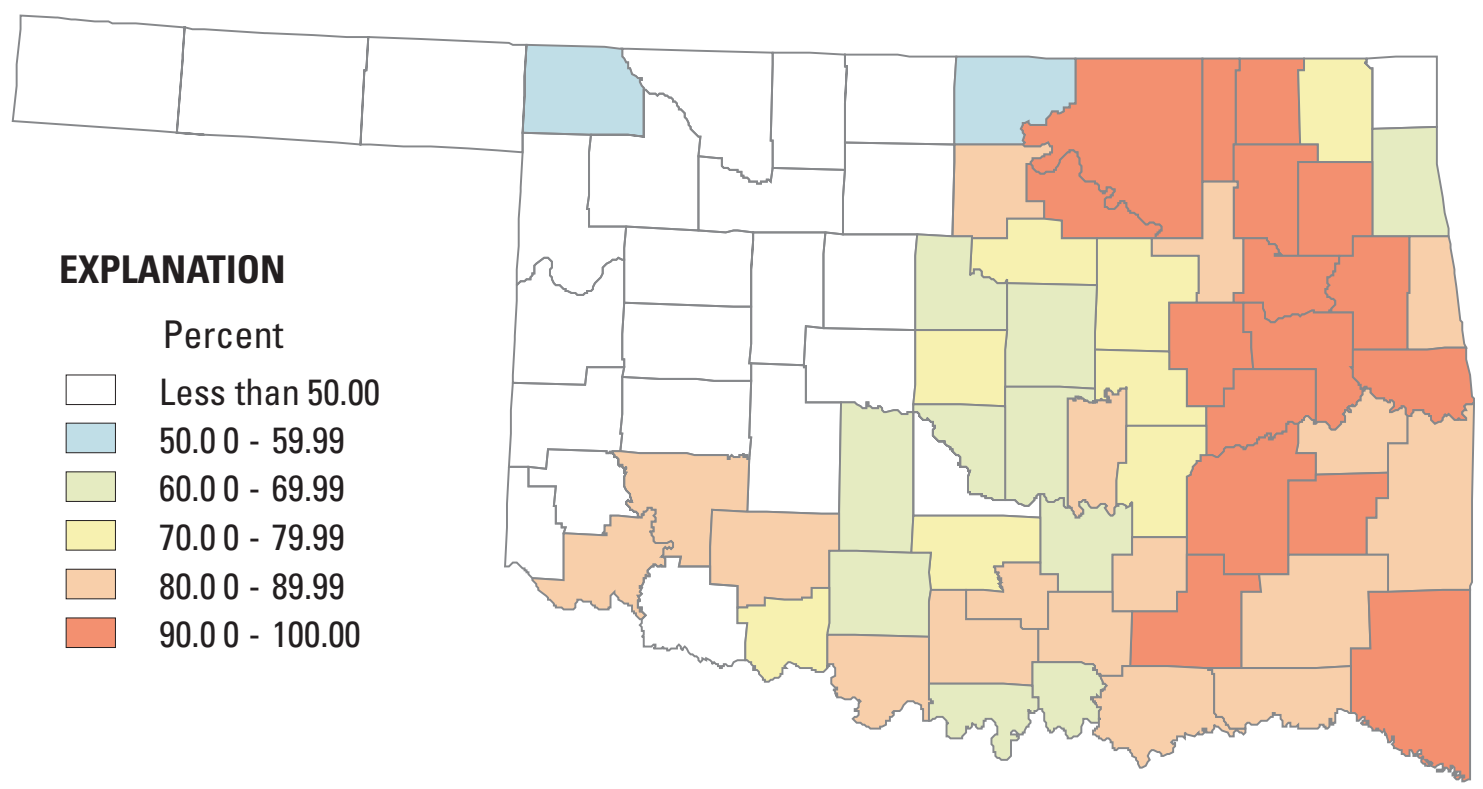

\section{Surface Water}

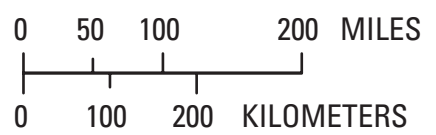

Albers Equal Area Conic Projection

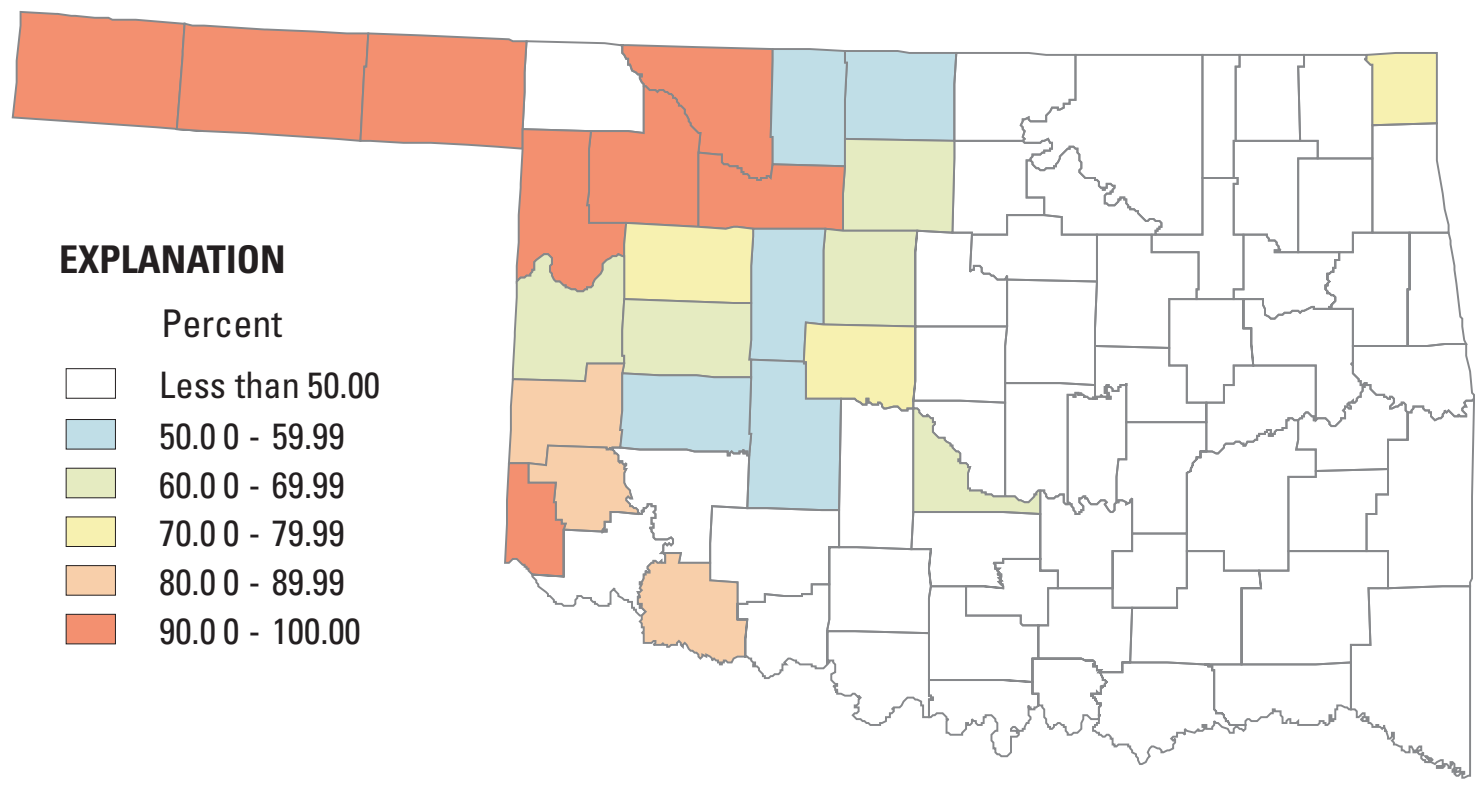

\section{Groundwater}

Figure 6. Freshwater withdrawals by percentage source and county in Oklahoma, 2005. 

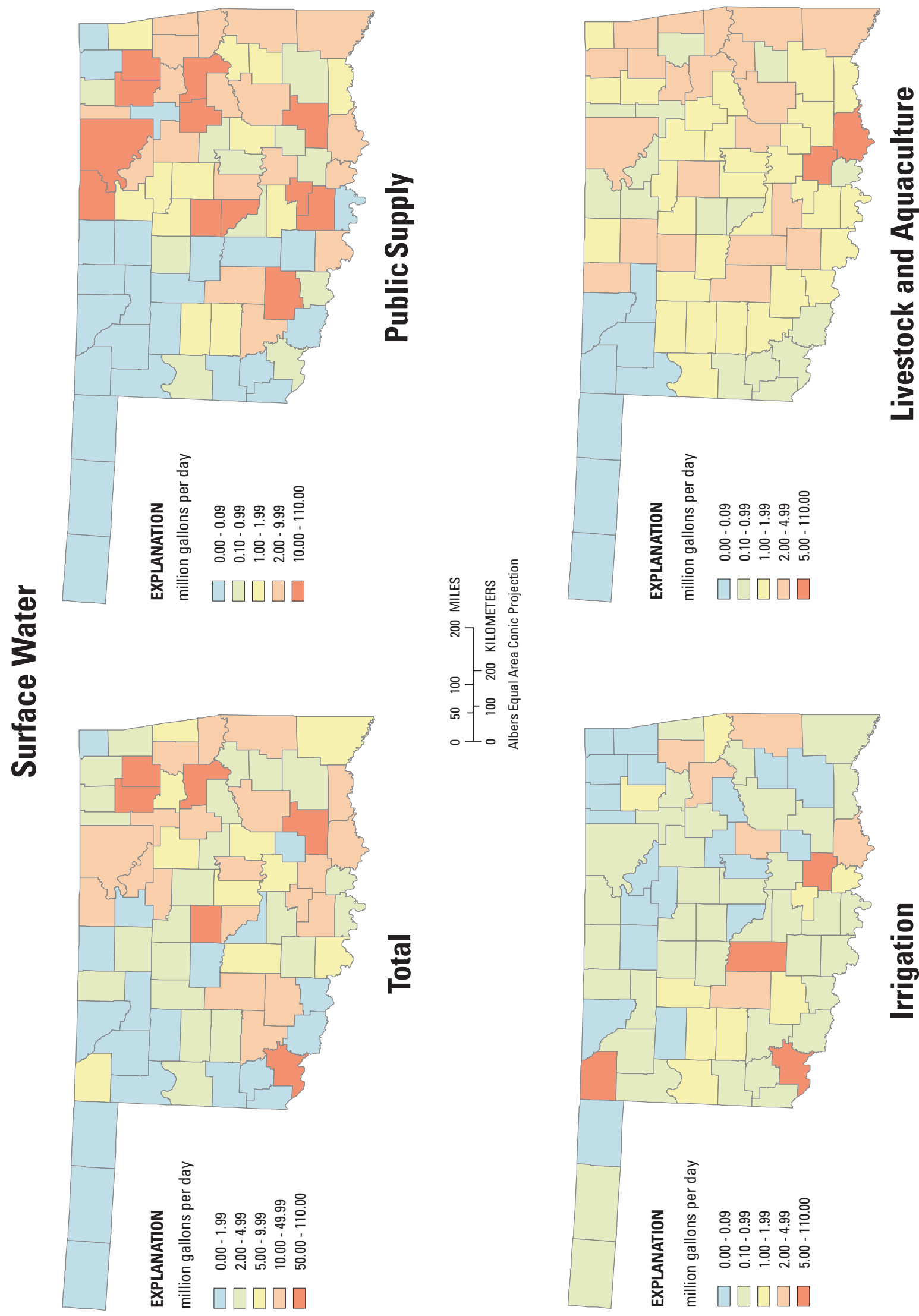

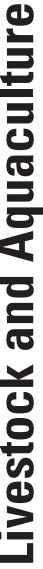

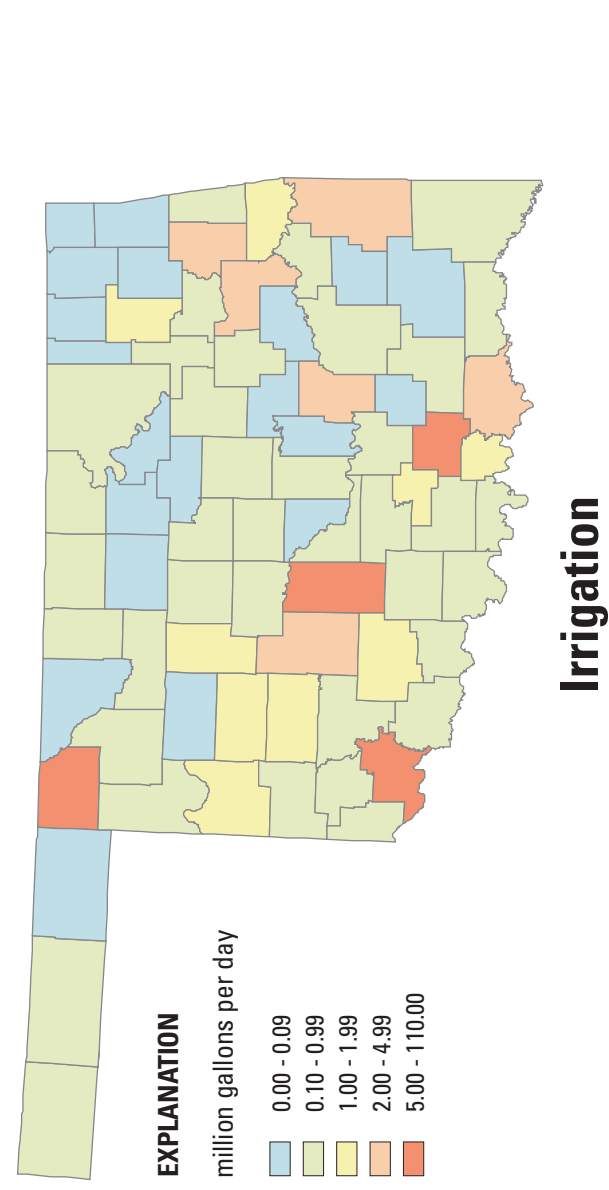

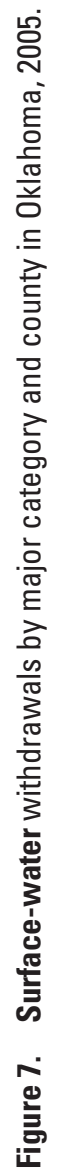




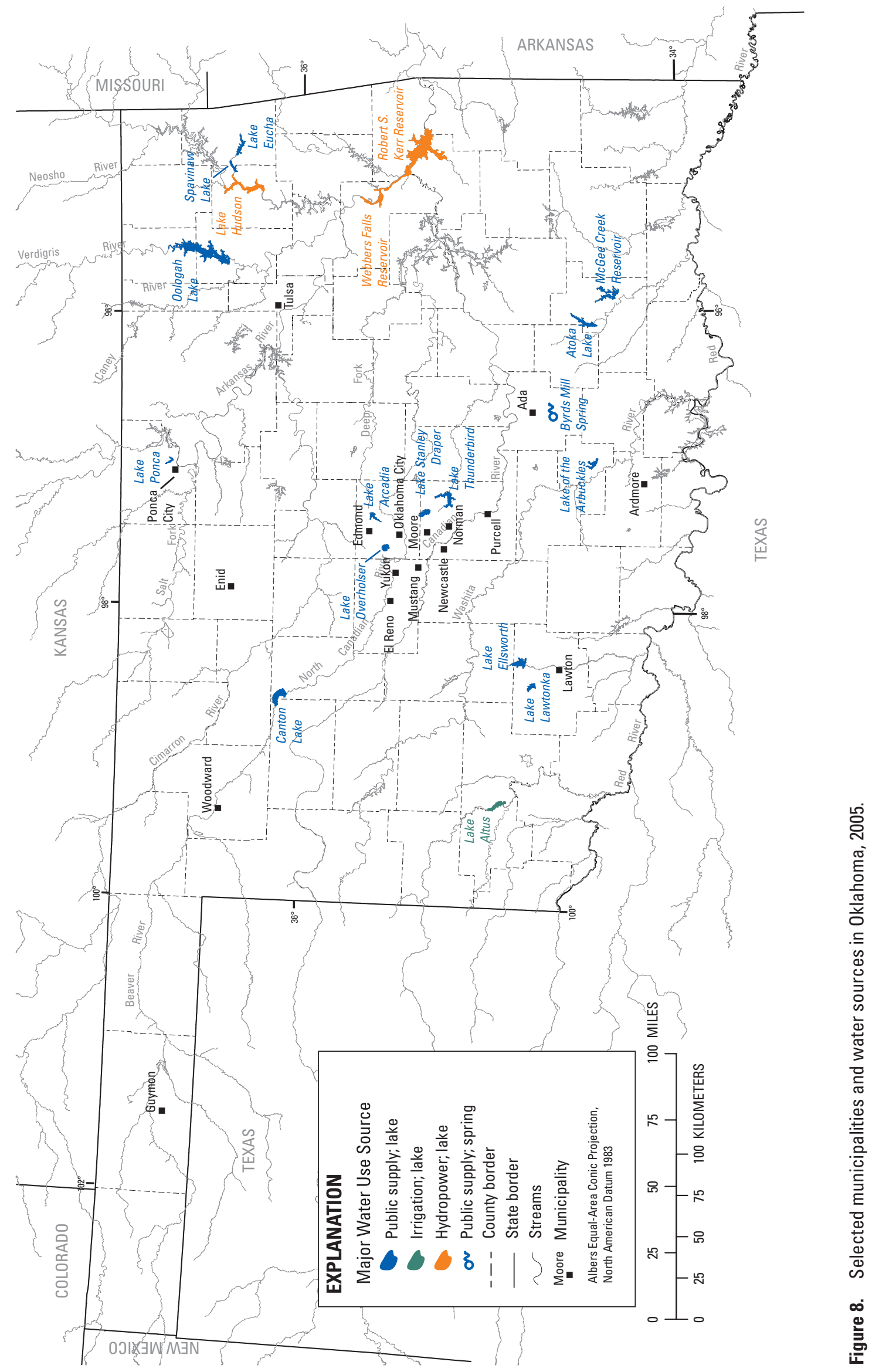



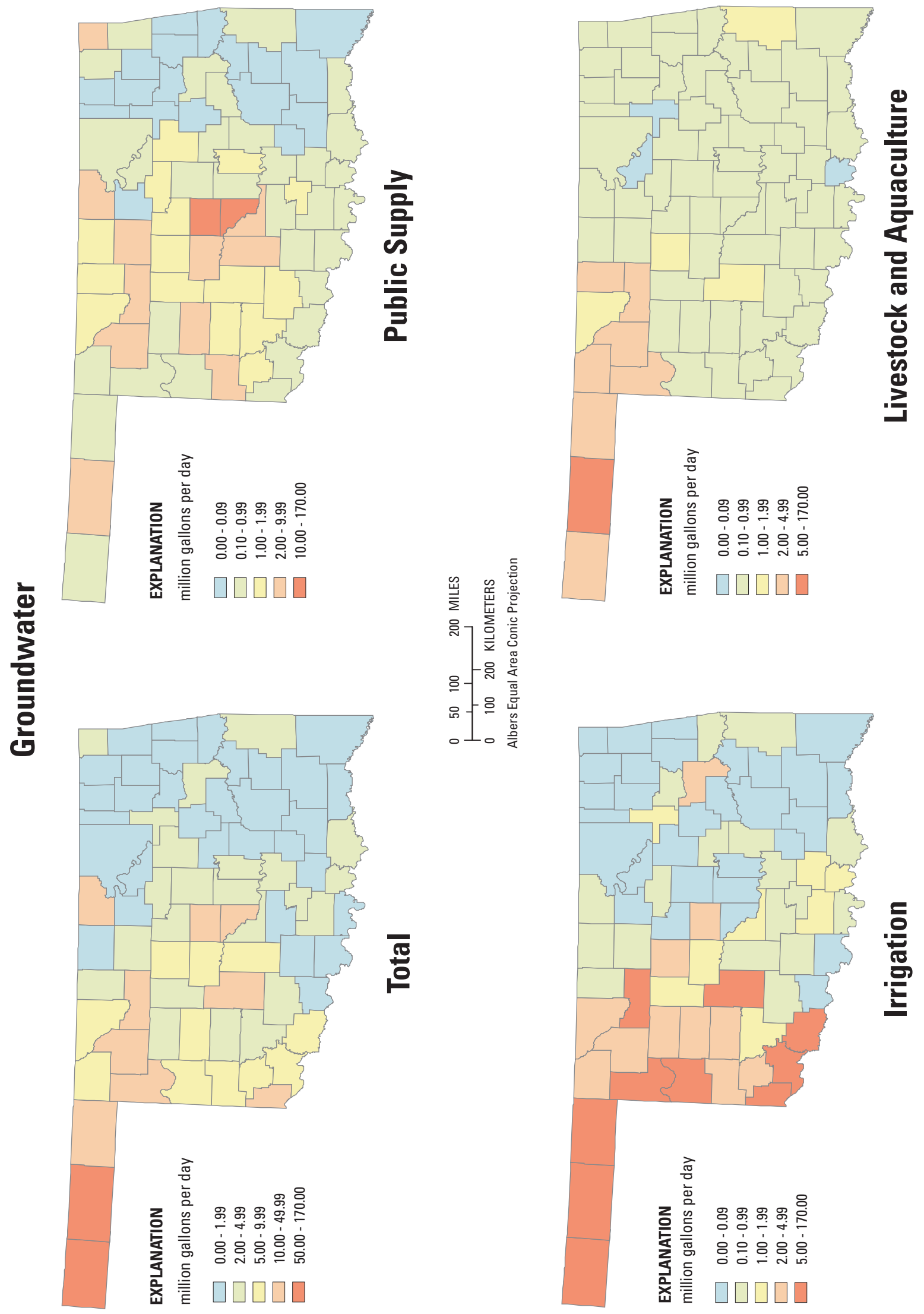

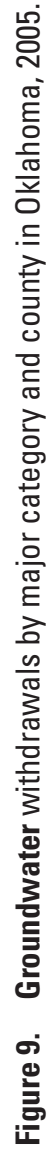




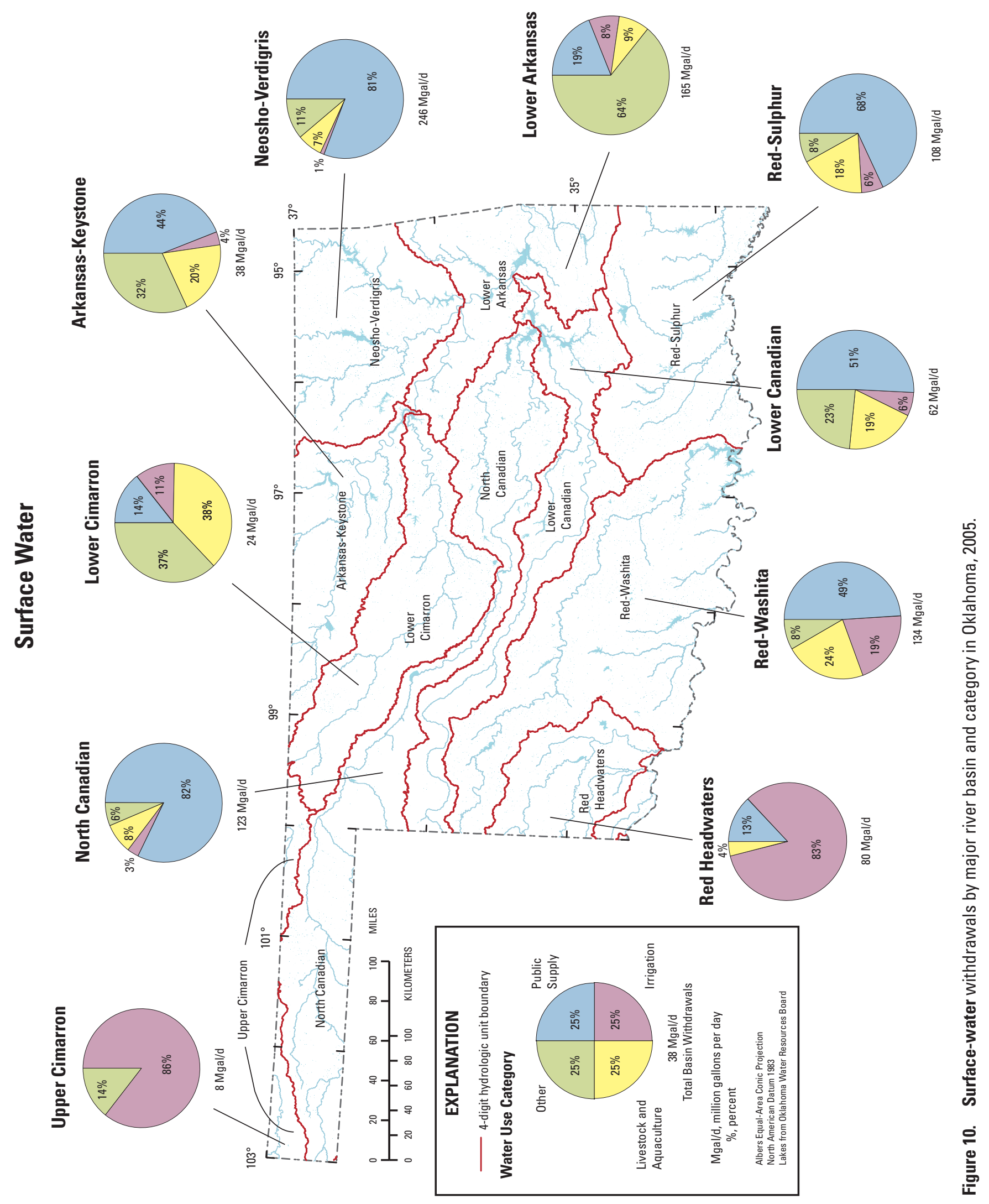




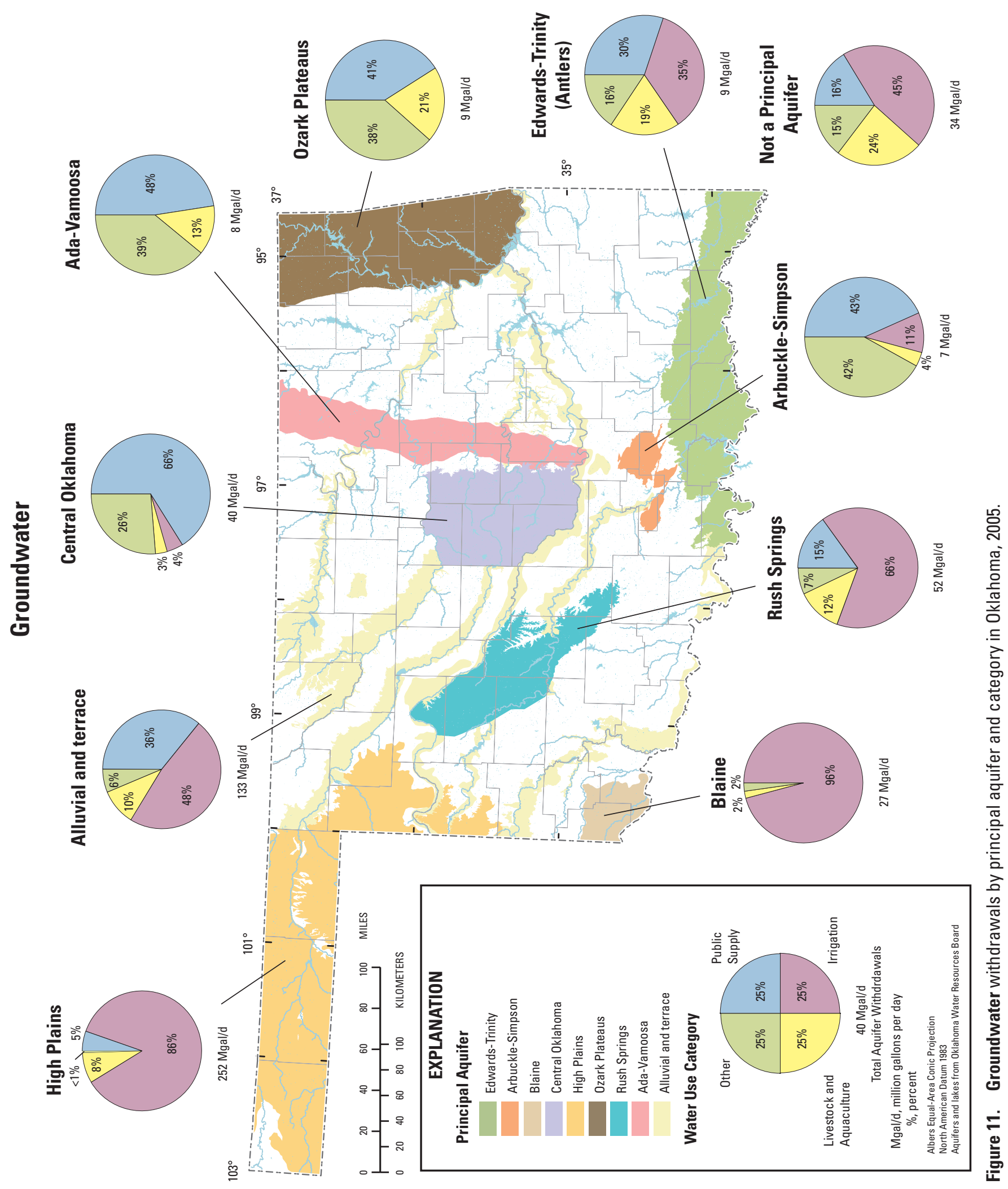


$\mathrm{Mgal} / \mathrm{d}$ or 18 percent withdrawn from groundwater sources (fig. 1, appendixes 1-3).

\section{Surface-Water Sources}

The largest public supply systems using surface-water sources were the City of Oklahoma City and City of Tulsa (fig. 8). The 2005 population of Oklahoma City was about 531,000 or 15 percent of the state total and the 2005 population of Tulsa was about 383,000 or 11 percent of the state total (S. Barker, Oklahoma Department of Commerce, written commun., 2008). Oklahoma City withdrew water from Lake Overholser in Oklahoma County (supplied by releases from Canton Lake); and from Lake Stanley Draper (supplied by pipeline from Atoka Lake and McGee Creek Reservoir in Atoka County) averaging about $122 \mathrm{Mgal} / \mathrm{d}$ or 23 percent of public supply surface-water withdrawals (L. Hare, City of Oklahoma City, written commun., 2007). Tulsa withdrew water from Spavinaw Lake in Mayes County and Oologah Lake in Rogers County averaging about $103 \mathrm{Mgal} / \mathrm{d}$ or 19 percent of public supply surface-water withdrawals (K. Rowland, City of Tulsa, written commun., 2007). Both systems supply several surrounding communities, the amount of withdrawals and population varies from year to year.

South-central Oklahoma is another area where surfacewater withdrawals were dominant. The largest public-supply systems in that part of the state were Ardmore (Carter County), which obtained most of the public-supply water from Lake of the Arbuckles, and Ada (Pontotoc County), which obtained water from Byrds Mill Spring (fig. 8, appendix 4). The 2005 combined population of these two systems was more than 41,000 or about 1 percent of the state total. These systems averaged about $19 \mathrm{Mgal} / \mathrm{d}$ or 4 percent of the public supply surface-water withdrawals. The largest surface-water publicsupply system in the southwest was Lawton (Commanche County), which obtained water from Lake Ellsworth and Lake Lawtonka (fig. 8, appendix 4). The 2005 population of Lawton was almost 89,000 or more than 2 percent of the state total. This system averaged about $16 \mathrm{Mgal} / \mathrm{d}$ or 3 percent of the public supply surface-water withdrawals.

Three agencies in Oklahoma supplied a substantial amount of surface water from the reservoirs and lakes these agencies operate: The U.S. Army Corps of Engineers, Bureau of Reclamation, and Grand River Dam Authority (U.S. Army Corps of Engineers, 2007; Bureau of Reclamation, 2007; Grand River Dam Authority, 2007). These agencies provided water to several municipalities and rural water districts. In 2005 the U.S. Army Corps of Engineers supplied more than $104 \mathrm{Mgal} / \mathrm{d}$ or almost 20 percent of the public supply surfacewater withdrawals (C. Shultz, Corps of Engineers, written commun., 2007). The Bureau of Reclamation in 2005 supplied more than $60 \mathrm{Mgal} / \mathrm{d}$ or about 11 percent of the public supply surface-water withdrawals (L. Hall, Bureau of Reclamation, written commun., 2007). The Grand River Dam Authority in
2005 supplied more than $42 \mathrm{Mgal} / \mathrm{d}$ or about 8 percent of the public supply surface-water withdrawals (A. Bishop, Grand River Dam Authority, written commun., 2007). Some of this water was included in the surface-water public supply systems mentioned earlier.

\section{Groundwater Sources}

Central Oklahoma is an area where groundwater sources were essential to public-supply systems. The largest systems in that part of the state were Edmond (Oklahoma County); Moore and Norman (Cleveland County); El Reno, Yukon, and Mustang (Canadian County); and Newcastle and Purcell (McClain County) (fig. 8, appendix 4). These withdrawals were mostly from the Central Oklahoma Aquifer and alluvial and terrace aquifers. The 2005 combined population from these central Oklahoma municipalities supplied by groundwater sources was about 150,000 or more than 4 percent of the state total. These systems averaged about $21 \mathrm{Mgal} / \mathrm{d}$ or $18 \mathrm{per}-$ cent of the public supply groundwater withdrawals. However, Edmond (water from Lake Arcadia), Moore (water purchased from Oklahoma City), and Norman (water from Lake Thunderbird) were examples of communities with mixed sources of public-supply water, where part of that supply was obtained from surface-water sources. An additional 135,000 people of these two communities, or less than 4 percent of the state total served, were supplied by surface-water sources.

North-central Oklahoma is another area where groundwater public-supply systems were essential. The largest systems in that part of the state were Enid (Garfield County), with a served population in 2005 of about 46,000 or 1.5 percent of the state total, and Ponca City (Kay County), with a served population about 20,000 or less than 1 percent of the state total (fig. 8, appendix 4). These two systems withdrew an average of more than $15 \mathrm{Mgal} / \mathrm{d}$ or about 13 percent of the public-supply groundwater withdrawals, mostly from alluvial and terrace aquifers. However, Ponca City is another example of mixed sources of public supply water with part of the supply from a surface-water source (water from Lake Ponca) that served about 5,000 additional people.

Northwest Oklahoma is an area where groundwater public supply withdrawals were dominant. The largest systems in that part of the state were Guymon (Texas County) and Woodward (Woodward County) (fig. 8, appendix 4). The 2005 combined population of these systems was more than 22,000 or less than 1 percent of the state total. These systems averaged about $10 \mathrm{Mgal} / \mathrm{d}$ or 8 percent of the public supply groundwater withdrawals, mostly from the High Plains Aquifer.

Note that many of the larger municipalities also sell water to the surrounding smaller municipalities and rural water districts. In addition to municipal public supply systems, Oklahoma has several hundred rural water districts (Oklahoma Department of Environmental Quality, 2008). Total withdrawals for public supply also are presented by source in ranked order for the top 10 counties in Oklahoma in table 2. 
Table 2. Estimated surface-water, groundwater, and total public supply freshwater withdrawals for top 10 counties in Oklahoma, 2005.

[Amounts are in million gallons per day. Totals may not add to totals because of independent rounding]

\begin{tabular}{ccccccc}
\hline Rank & County & $\begin{array}{c}\text { Total } \\
\text { surface } \\
\text { water }\end{array}$ & County & $\begin{array}{c}\text { Total } \\
\text { ground- } \\
\text { water }\end{array}$ & County & $\begin{array}{c}\text { Total } \\
\text { water }\end{array}$ \\
\hline 1 & Mayes & 93 & Oklahoma & 18 & Oklahoma & 94 \\
2 & Oklahoma & 76 & Cleveland & 11 & Mayes & 93 \\
3 & Rogers & 65 & Kay & 7 & Rogers & 65 \\
4 & Atoka & 54 & Woodward & 7 & Atoka & 54 \\
5 & Cleveland & 21 & Major & 6 & Cleveland & 32 \\
6 & Commanche & 16 & Texas & 6 & Kay & 20 \\
7 & Muskogee & 14 & Beckham & 4 & Commanche & 18 \\
8 & Carter & 14 & Garfield & 4 & Carter & 15 \\
10 & Okmulgee & 14 & Custer & 3 & Muskogee & 15 \\
\hline 9 & Osage & 14 & Ottawa & 3 & Okmulgee & 14 \\
\hline
\end{tabular}

\section{Irrigation}

Irrigation systems in Oklahoma applied water to more than 472,000 acres, of which about 87,000 acres, or 18 percent, were irrigated by surface irrigation (includes flood, furrow, or gravity irrigation) and about 385,000 acres, or 81 percent, were irrigated by sprinkler irrigation (includes center pivot and micro irrigation). Most of irrigation water was withdrawn from groundwater sources. Groundwater sources supplied $361 \mathrm{Mgal} / \mathrm{d}$ or 73 percent of total irrigation withdrawals and surface-water sources supplied $134 \mathrm{Mgal} / \mathrm{d}$ or 27 percent of total irrigation withdrawals (fig. 1, appendixes 1-3).

Groundwater withdrawals for irrigation in the Oklahoma Panhandle (Cimarron, Texas, and Beaver Counties), about 217 $\mathrm{Mgal} / \mathrm{d}$, represented about 60 percent of groundwater withdrawals and 44 percent of all irrigation withdrawals in Oklahoma (table 3, appendix 1). Most of the water was withdrawn from the High Plains Aquifer and main crops were wheat and corn.

Surface-water withdrawals for irrigation in Jackson County, about $65 \mathrm{Mgal} / \mathrm{d}$, represented about 49 percent of surface-water withdrawals and 13 percent of all irrigation withdrawals in Oklahoma (table 3, appendix 1). The largest surface-water irrigation user was the Altus-Lugert Irrigation District, Jackson County, which withdrew about $58 \mathrm{Mgal} / \mathrm{d}$, or about 43 percent of surface-water withdrawals and 12 percent of all irrigation withdrawals. The water was withdrawn from Lake Altus in the Red Headwaters River Basin (figs. 8 and 10) and cotton was the main crop.

Irrigation withdrawals are highly dependent on such factors as application method, crop type, acreage irrigated, seasonal climate, and economics such as crop prices, depth to water, and power costs. Total withdrawals for irrigation also are presented by source in ranked order for the top 10 counties in Oklahoma in table 3.

\section{Livestock and Aquaculture}

The largest livestock and aquaculture water withdrawals in Oklahoma were for the cattle industry (National Agricultural Statistics Service, 2006). An inventory on January 1, 2006, indicated 5,450,000 cattle and calves and 2,075,000 beef cows. The hog industry had an inventory of 2,370,000 hogs and pigs on January 1, 2006, with more than half of the 
Table 3. Estimated surface-water, groundwater, and total irrigation freshwater withdrawals for top 10 counties in Oklahoma, 2005.

[Amounts are in million gallons per day. Totals may not add to totals because of independent rounding]

\begin{tabular}{|c|c|c|c|c|c|c|}
\hline Rank & County & $\begin{array}{c}\text { Total } \\
\text { Surface } \\
\text { Water }\end{array}$ & County & $\begin{array}{c}\text { Total } \\
\text { Ground- } \\
\text { water }\end{array}$ & County & $\begin{array}{l}\text { Total } \\
\text { Water }\end{array}$ \\
\hline 1 & Jackson & 65 & Texas & 149 & Texas & 149 \\
\hline 2 & Harper & 7 & Cimarron & 47 & Jackson & 74 \\
\hline 3 & Grady & 6 & Harmon & 25 & Cimarron & 48 \\
\hline 4 & Johnston & 5 & Caddo & 24 & Caddo & 28 \\
\hline 5 & Muskogee & 5 & Beaver & 21 & Harmon & 25 \\
\hline 6 & Bryan & 4 & Ellis & 13 & Beaver & 21 \\
\hline 7 & Cherokee & 4 & Jackson & 9 & Ellis & 13 \\
\hline 8 & Caddo & 4 & Major & 9 & Harper & 11 \\
\hline 9 & Le Flore & 4 & Tillman & 8 & Major & 9 \\
\hline 10 & Hughes & 2 & Roger Mills & 5 & Tillman & 8 \\
\hline
\end{tabular}

animals in the Panhandle District (National Agricultural Statistics Service, 2006). Poultry was a major industry in northeastern and southeastern Oklahoma.

Most of livestock and aquaculture water was withdrawn from surface-water sources. Livestock and aquaculture had $126 \mathrm{Mgal} / \mathrm{d}$ or 70 percent withdrawn from surface-water sources and $55 \mathrm{Mgal} / \mathrm{d}$ or 30 percent withdrawn from groundwater sources (fig. 1, appendixes 1-3).

The influence of aquaculture on livestock surface-water withdrawals can be seen in south-central Oklahoma, where Johnston and Bryan counties had surface-water withdrawals totaling about $13 \mathrm{Mgal} / \mathrm{d}$ or about two-thirds of total aquaculture withdrawals. Aquaculture accounts for about $19 \mathrm{Mgal} / \mathrm{d}$ or about 11 percent of total livestock and aquaculture withdrawals (2005 Oklahoma AWUDS report tables). The influence of livestock operations on groundwater withdrawals can be seen in the northwest, especially the panhandle (Cimarron, Texas, and Beaver Counties) with about $19 \mathrm{Mgal} / \mathrm{d}$ or about 34 percent of total livestock and aquaculture groundwater with- drawals (appendix 1). Total withdrawals for livestock and aquaculture also are presented by source in ranked order for the top 10 counties in Oklahoma in table 4.

\section{Other Uses}

The other uses include the self-supplied uses for thermoelectric power generation, domestic, commercial, industrial and mining (fig. 3, see glossary). Surface water provides most of self-supplied thermoelectric power generation, commercial, industrial and mining uses; whereas, groundwater provides all self-supplied domestic use.

Deliveries from public-supply providers for domestic, commercial, industrial, and thermoelectric power generation uses are included in public-supply withdrawals (fig. 4). Almost 92 percent of all domestic and commercial water in 2005 was from public-water suppliers (figs. 3 and 4, appendix 1). About 83 percent of total industrial water uses in 2005 was from public-water suppliers (figs. 3 and 4). 
Table 4. Estimated surface-water, groundwater, and total livestock and aquaculture freshwater withdrawals for top 10 counties in Oklahoma, 2005.

[Amounts are in million gallons per day. Totals may not add to totals because of independent rounding]

\begin{tabular}{ccccccc}
\hline Rank & County & $\begin{array}{c}\text { Total } \\
\text { Surface } \\
\text { Water }\end{array}$ & County & $\begin{array}{c}\text { Total } \\
\text { Ground- } \\
\text { water }\end{array}$ & County & $\begin{array}{c}\text { Total } \\
\text { Water }\end{array}$ \\
\hline 1 & Johnston & 8 & Texas & 11 & Texas & 11 \\
2 & Bryan & 8 & Beaver & 4 & Bryan & 9 \\
3 & Osage & 4 & Major & 4 & Johnston & 8 \\
4 & Grady & 4 & Harper & 3 & Osage & 4 \\
5 & Haskell & 3 & Cimarron & 3 & Beaver & 4 \\
6 & Le Flore & 3 & Woodward & 3 & Alfalfa & 4 \\
7 & Kingfisher & 3 & Ellis & 2 & Grady & 4 \\
8 & Caddo & 3 & Alfalfa & 2 & Kingfisher & 4 \\
9 & Pittsburg & 3 & Woods & 2 & Caddo & 4 \\
\hline 10 & Hughes & 2 & Kingfisher & 1 & Le Flore & 4 \\
\hline
\end{tabular}

\section{Thermoelectric Power Generation}

Thermoelectric power generation requires large amounts of cooling water (see glossary). This category was the next largest water withdrawal category after the three major categories, and accounts for about $163 \mathrm{Mgal} / \mathrm{d}$ or about 16 percent of surface water withdrawn (fig. 3, appendixes 1 and 2). Almost all the withdrawals were from surface-water sources, predominantly in the eastern half of the state with more than half of withdrawals in the Lower Arkansas River Basin (fig. 10, appendix 2) (U.S. Department of Energy, 2006).

\section{Domestic (Self-Supplied)}

Self-supplied domestic withdrawals were assumed to be from groundwater sources (fig. 3). Domestic use of water for the people in Oklahoma that are not served by public supply is in the self-supplied domestic category. The self-supplied population included about 295,000 people or about 29 percent of the population supplied by groundwater sources and about 8 percent of the total population of Oklahoma (appendixes 1 and 3). Most of the population in Oklahoma was supplied by municipal or rural water district public-supply systems.

\section{Commercial}

Most of water withdrawn for motels, hotels, restaurants, office buildings, and other commercial uses was delivered from public-supply systems with $171 \mathrm{Mgal} / \mathrm{d}$ or about 84 percent of delivered commercial withdrawals from surface-water sources (fig. 4). The largest commercial uses delivered from public-supply systems were in Oklahoma City (50 Mgal/d) and Tulsa (27 Mgal/d), as estimated from major customer lists.

Self-supplied commercial withdrawals were about 21 $\mathrm{Mgal} / \mathrm{d}$ or just 10 percent of the amount of delivered commercial withdrawals. Most of self-supplied commercial withdrawals were from surface-water sources, about $17 \mathrm{Mgal} / \mathrm{d}$ or about 79 percent. 


\section{Industrial}

Most of water withdrawn for chemical and allied products, food, mining, paper and allied products, petroleum refining, steel, and other industrial uses was delivered from public-supply systems. Surface-water sources were $98 \mathrm{Mgal} / \mathrm{d}$ or about 86 percent of industrial deliveries (fig. 4). The largest industrial uses delivered from public supply systems were from Oklahoma City (18 Mgal/d) and Tulsa (20 Mgal/d), as estimated from major customer lists.

Self-supplied industrial withdrawals were about 24 $\mathrm{Mgal} / \mathrm{d}$ or just 21 percent of the amount of delivered industrial withdrawals. Most of self-supplied industrial withdrawals were from surface-water sources, about $16 \mathrm{Mgal} / \mathrm{d}$ or about 67 percent.

\section{Mining (Self-Supplied)}

Freshwater withdrawals for water used for the extraction of naturally occurring minerals including solids, such as coal, sand, gravel, and other ores; liquids, such as crude petroleum; and gases, such as natural gas were small, about $3 \mathrm{Mgal} / \mathrm{d}$, with most of the water withdrawn from surface-water sources (fig. 3). However, a potential exists for a large increase for withdrawals in this water-use category-water can be used for shale gas well hydraulic fracturing (Schein, 2008). This category also includes uses associated with quarrying, milling, and other preparations customarily done at the mine site.

\section{Hydroelectric Power}

Water that is used, but not withdrawn, from a surfacewater source such as hydroelectric power generation, navigation, water-quality improvement, fish propagation, and recreation is referred to as an instream use (see glossary). This water was not included in the freshwater withdrawal estimates presented in appendixes 1 and 2. However, hydroelectric power generation is a major water use that is greatly affected by climate, because during drought years when streamflow is low, less power was produced by hydroelectric facilities (Tortorellli, 2008). Instream water-use estimates for hydroelectric power are included in table 5 .

More than 50 percent of the hydroelectric power water use was in three plants in eastern Oklahoma: Robert S. Kerr Reservoir (LeFlore County), Webbers Falls Reservoir (Muskogee County) (J. Croston, Southwest Power Administration, 2007), and Lake Hudson (Mayes County) (A. Bishop, Grand River Dam Authority, written commun., 2007) (fig. 8). These three plants generated more than 1,000 gigawatt hours of electricity in 2005 , or about 40 percent of the hydroelectric power generated in Oklahoma (table 5).

\section{Comparison of Water Use 1990-2005}

In this section the total freshwater withdrawals for the three major and other categories of water use are compared graphically in 5-year intervals from 1990-2005. Also the freshwater withdrawals for the three major water-use categories are compared graphically in 5-year intervals from 1990-2005 by (1) major river basin withdrawals, and (2) principal aquifer withdrawals.

\section{Total Withdrawals by Category}

Public-supply water withdrawals increased steadily from 1990-2000 and then decreased slightly in 2005 (fig. 12A), mainly because of a decrease in surface-water withdrawals. The total population of the state and the population served by public-supplied surface water have increased steadily; whereas, the population served by public-supplied groundwater has remained about the same, and the self-supplied population has steadily decreased (fig. 12B). Self-supplied population has decreased in part because of the increased number of rural water districts in rural Oklahoma (Oklahoma Water Resources Board, 1998). Also the self-supplied population has slowly decreased because of loss of population in many rural counties. In addition more rural water districts are withdrawing more water from surface-water sources. Surface-water public supply withdrawals probably decreased slightly because of climate, because the summer of 2000 was much drier than the summer of 2005. Also a 3-percent decrease in commercial and 16 percent in industrial deliveries was reported from 2000 2005 (J. Kenny, U.S. Geological Survey, written commun., 2009).

Irrigation water withdrawals increased to about 864 $\mathrm{Mgal} / \mathrm{d}$ or 44 percent from 1990-1995 and then decreased steadily to $495 \mathrm{Mgal} / \mathrm{d}$ in 2005 (fig. 13A). Surface-water irrigation withdrawals decreased about 12 percent from 2000-2005. Irrigation water withdrawals depend on application method, crop type, acreage irrigated, seasonal climate, and economics. Irrigated acreage in 2005 was 16 percent less than in 1995, but irrigation water withdrawals in 2005 were 43 percent less than in 1995 withdrawals. Part of the reason less water was used was that application methods have been evolving to use more sprinkler application (including some micro irrigation) and less surface application on irrigated acreage; acreage irrigated with sprinkler application remained about the same from 1995-2005; whereas, acreage that used surface application decreased by more than half from 1995-2005 (fig. 13B).

Total livestock and aquaculture water withdrawals steadily increased from 1990-2005. Animal livestock must be described separately to understand the increase. Cattle numbers have remained about the same from 1990-2005. However, hogs have increased 10 fold and broiler chickens 
Table 5. Estimated freshwater surface-water use and power generated by hydroelectric power by county and major river basin in Oklahoma, 2005.

[GWh, Gigawatt-hour; Mgal/d, million gallons per day. Totals may not add to totals because of independent rounding. SWPA, Southwest Power Administration; GRDA, Grand River Dam Authority; OMPA, Oklahoma Municpal Power Authority]

\begin{tabular}{|c|c|c|c|c|c|c|c|c|}
\hline \multirow[b]{2}{*}{ Dam/Reservoir } & \multirow[b]{2}{*}{ Agency } & \multirow{2}{*}{$\begin{array}{l}\text { County } \\
\text { name }\end{array}$} & \multirow{2}{*}{$\begin{array}{c}\text { Majo } \\
\text { river basin }\end{array}$} & \multicolumn{2}{|c|}{ Net GWh } & \multicolumn{2}{|c|}{ Water Use } & \multirow{2}{*}{$\begin{array}{l}\text { Average } \\
\text { Mgal/d per } \\
\text { GWh }\end{array}$} \\
\hline & & & & $\begin{array}{c}\text { Instream } \\
\text { power }\end{array}$ & $\begin{array}{c}\text { Offstream } \\
\text { power }\end{array}$ & $\begin{array}{l}\text { Instream } \\
\text { Mgal/d }\end{array}$ & $\begin{array}{c}\text { Offstream } \\
\text { Mgal/d }\end{array}$ & \\
\hline Broken Bow & SWPA & McCurtain & Red-Sulphur & 98 & & 525 & & 5 \\
\hline Fort Gibson & SWPA & Cherokee & Neosho-Verdigris & 231 & & 3,867 & & 17 \\
\hline $\begin{array}{l}\text { Robert S. Kerr/ } \\
\text { (Lake Hudson) }\end{array}$ & GRDA & Mayes & Neosho-Verdigris & 235 & & 4,718 & & 20 \\
\hline Kaw & OMPA & Kay & Arkansas-Keystone & 130 & & 1,737 & & 13 \\
\hline Keystone & SWPA & Tulsa & Arkansas-Keystone & 310 & & 3,773 & & 12 \\
\hline $\begin{array}{l}\text { Pensacola/ } \\
\text { (Lake O' the Cherokees) }\end{array}$ & GRDA & Mayes & Neosho-Verdigris & 452 & & 3,807 & & 8 \\
\hline Robert S. Kerr & SWPA & LeFlore & Lower Arkansas & 580 & & 13,207 & & 23 \\
\hline
\end{tabular}

have almost doubled from 1990-2005, resulting in increased water withdrawals for these livestock (National Agricultural Statistics Service, 1991 and 2006). Surface-water withdrawals have remained about the same, but groundwater withdrawals for livestock have increased by 55 percent from 1990-2005. Aquaculture withdrawals have steadily increased (fig. 14A). Nearly all aquaculture use is from surface water in Oklahoma (1990-2005 Oklahoma AWUDS report tables).

The largest increase in the other water-use categories was thermoelectric power generation that has steadily increased and almost doubled from 1990-2005 (fig. 14B). Nearly all thermoelectric power generation use is from surface water in
Oklahoma (1990-2005 Oklahoma AWUDS tables). The other self-supplied water use categories had much smaller and varied changes in withdrawals during these years.

\section{Withdrawals by Major River Basin}

Public-supply withdrawals from surface-water sources increased steadily from 1990-2005 in the two major river basins with the largest public-supply withdrawals in 2005the Neosho-Verdigris River Basin-mainly because of the Grand River Dam Authority and the City of Tulsa withdrawals, and the North Canadian River Basin-mainly because of 

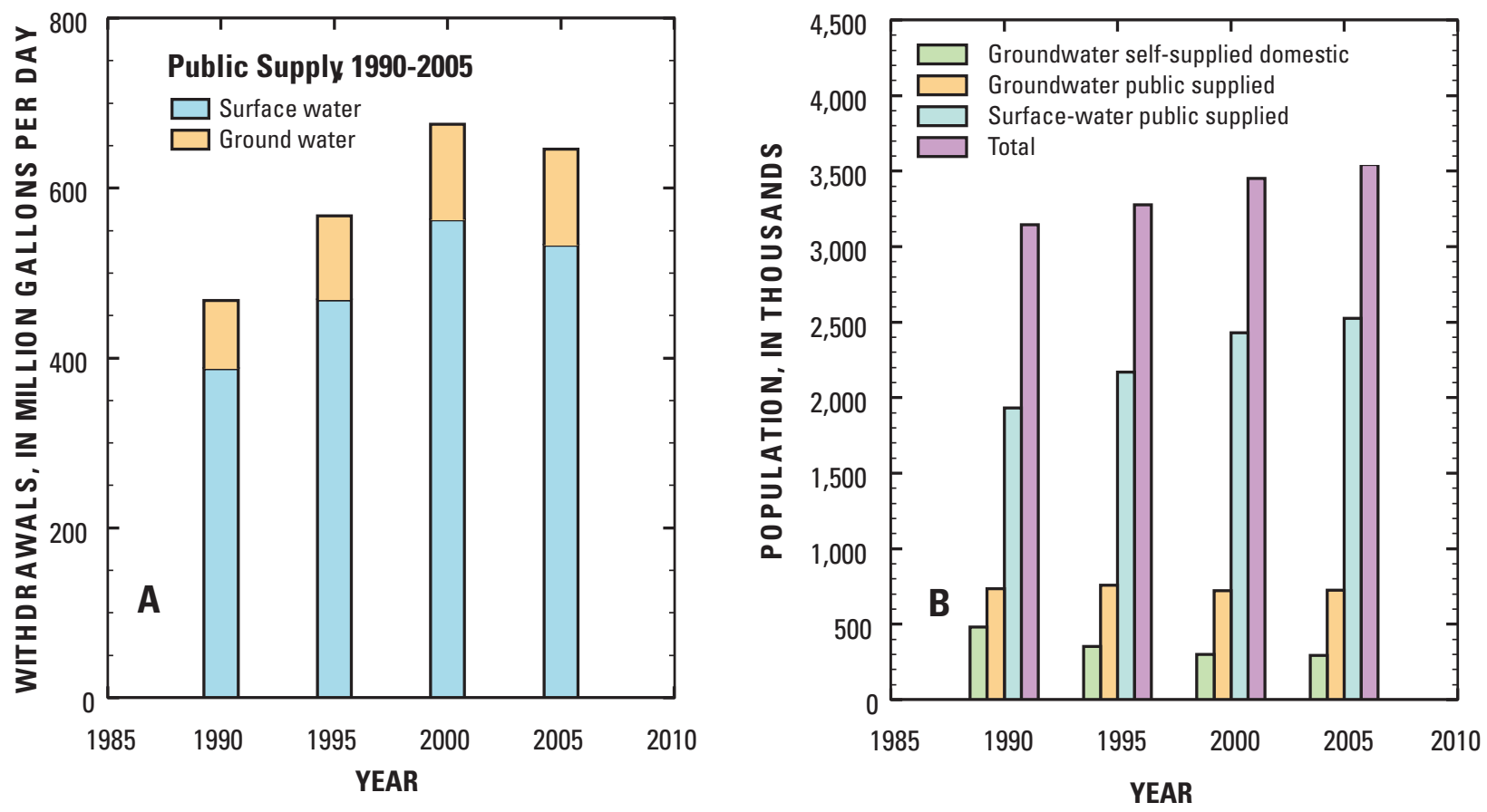

Figure 12. (A) Public supply withdrawals by source in Oklahoma, 1990-2005 (B) Population by source of water in Oklahoma, 1990-2005.
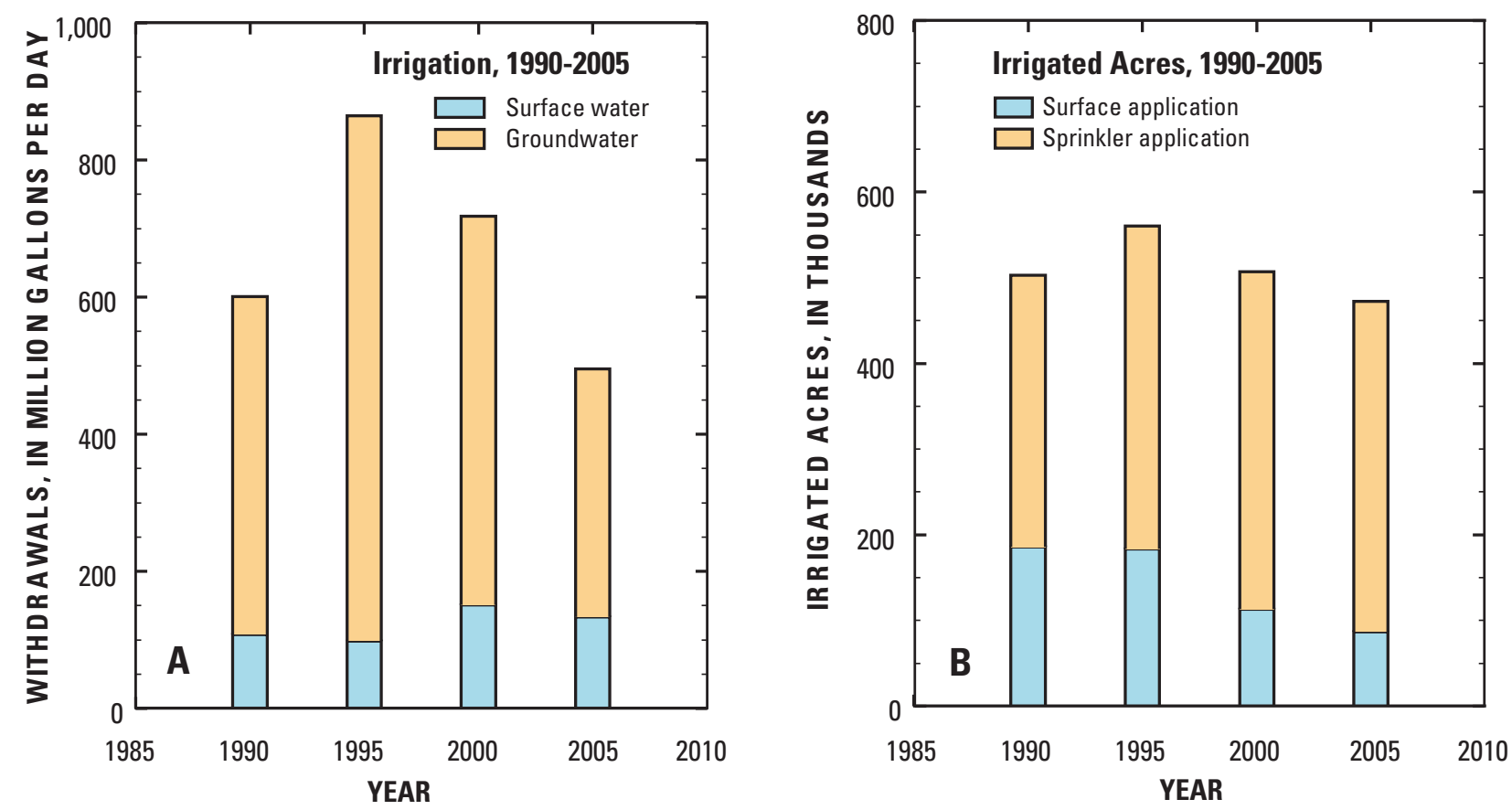

Figure 13. (A) Irrigation withdrawals by source in 0klahoma, 1990-2005 (B) Irrigated acres by application method in Oklahoma, 1990-2005. 

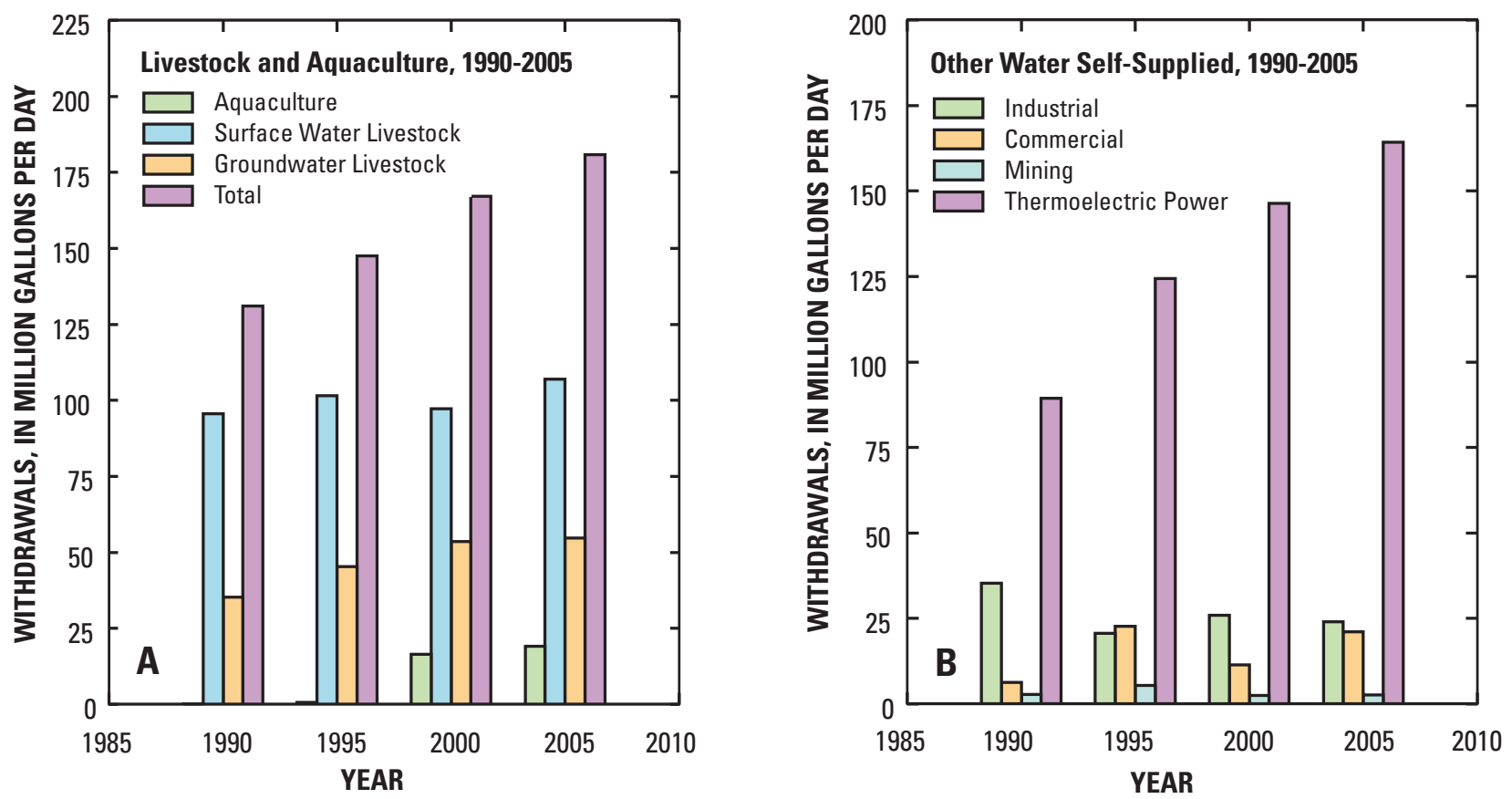

Figure 14. (A) Livestock and aquaculture withdrawals by source in Oklahoma, 1990-2005 (B) Other water self-supplied by category in Oklahoma, 1990-2005.

the City of Oklahoma City withdrawals (figs. 8, 10, and 15A). Public-supply withdrawals increased steadily from 1990-2000 and then decreased slightly in 2005 in the two major river basins with the next largest withdrawals in 2005 - the RedWashita River Basin - mainly because of the City of Ardmore withdrawals; and the Red-Sulphur River Basin - mainly because of the City of Oklahoma City withdrawals (fig. 8, 10, and $15 \mathrm{~A}$ ).

Irrigation surface-water withdrawals decreased in 2005 from a peak in 2000 in the major river basin with the largest irrigation withdrawals - the Red Headwaters River Basin (fig. 10 and 15B). The decrease in withdrawals was mainly because of the Altus-Lugert Irrigation District that receives water from Lake Altus (fig. 8). Although acreage irrigated remained about the same in the Irrigation District, summer rainfall amounts were much more in 2005 compared to 2000 . This example illustrates the effect of climate on irrigation withdrawals (Oklahoma Climatological Survey, 2008a, 2008b).

Livestock and aquaculture surface-water withdrawals increased steadily from 1990-2005 in the two major river basins with the largest withdrawals in 2005 - the Red-Washita River Basin, and the Red-Sulphur River Basin (figs. 10 and $15 \mathrm{C}$ ). Livestock and aquaculture withdrawals in most river basins have increased steadily from 1990-2005 (fig. 15C).

\section{Withdrawals by Principal Aquifer}

Public-supply withdrawals from groundwater sources increased steadily from 1990-2000 and then decreased slightly in 2005 in the principal aquifer with the largest withdrawalsthe alluvial and terrace aquifers. This decrease was mainly because of groundwater public-supply systems in central Oklahoma area, El Reno and Yukon (Canadian County) and Newcastle (McClain County); in north-central Oklahoma, Enid (Garfield County) and Ponca City (Kay County) (figs. 8,11 , and 16A); and dozens of small towns and rural water districts statewide.

Public-supply withdrawals increased steadily from 19902005 in the principal aquifer with the next largest volume of withdrawals - the Central Oklahoma Aquifer. This increase was mainly because of groundwater public-supply systems in central Oklahoma area, Edmond (Oklahoma County), Moore and Norman (Cleveland County), Mustang (Canadian County); and several small towns (figs. 8, 11, and 16A).

Irrigation groundwater withdrawals increased from 1990-1995 and then decreased steadily to 2005 in the principal aquifer with the largest withdrawals - the High Plains Aquifer - mainly because of irrigation in the panhandle (Cimarron, Texas, and Beaver Counties) (fig. 11 and 16B). Groundwater irrigation withdrawals remained about the same 

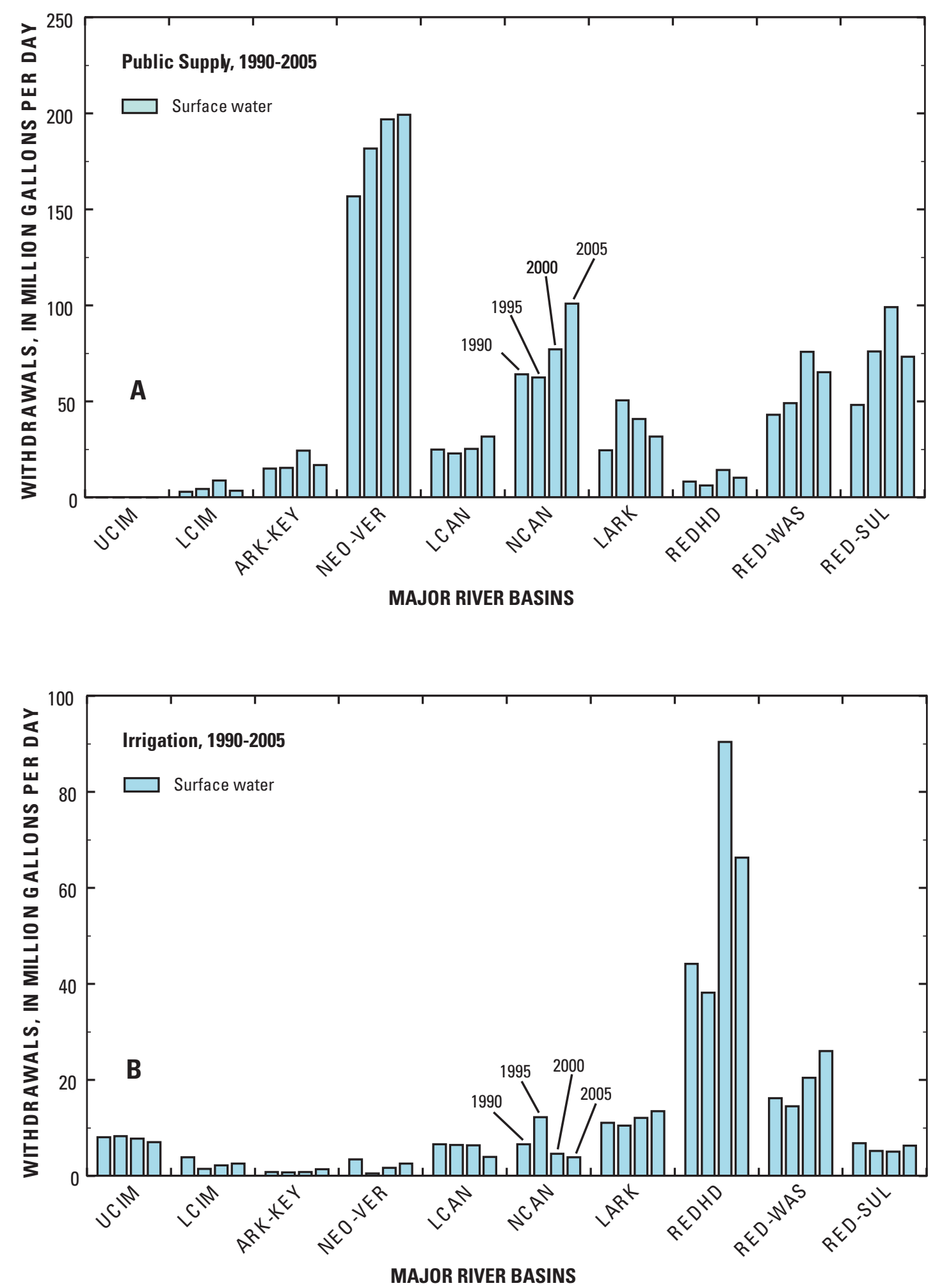

Figure 15. (A) Public supply surface-water withdrawals by major river basin in Oklahoma, 1990-2005 (B) Irrigation surface-water withdrawals by major river basin in Oklahoma, 1990-2005 (C) Livestock and aquaculture surface-water withdrawals by major river basin in Oklahoma, 1990-2005. 


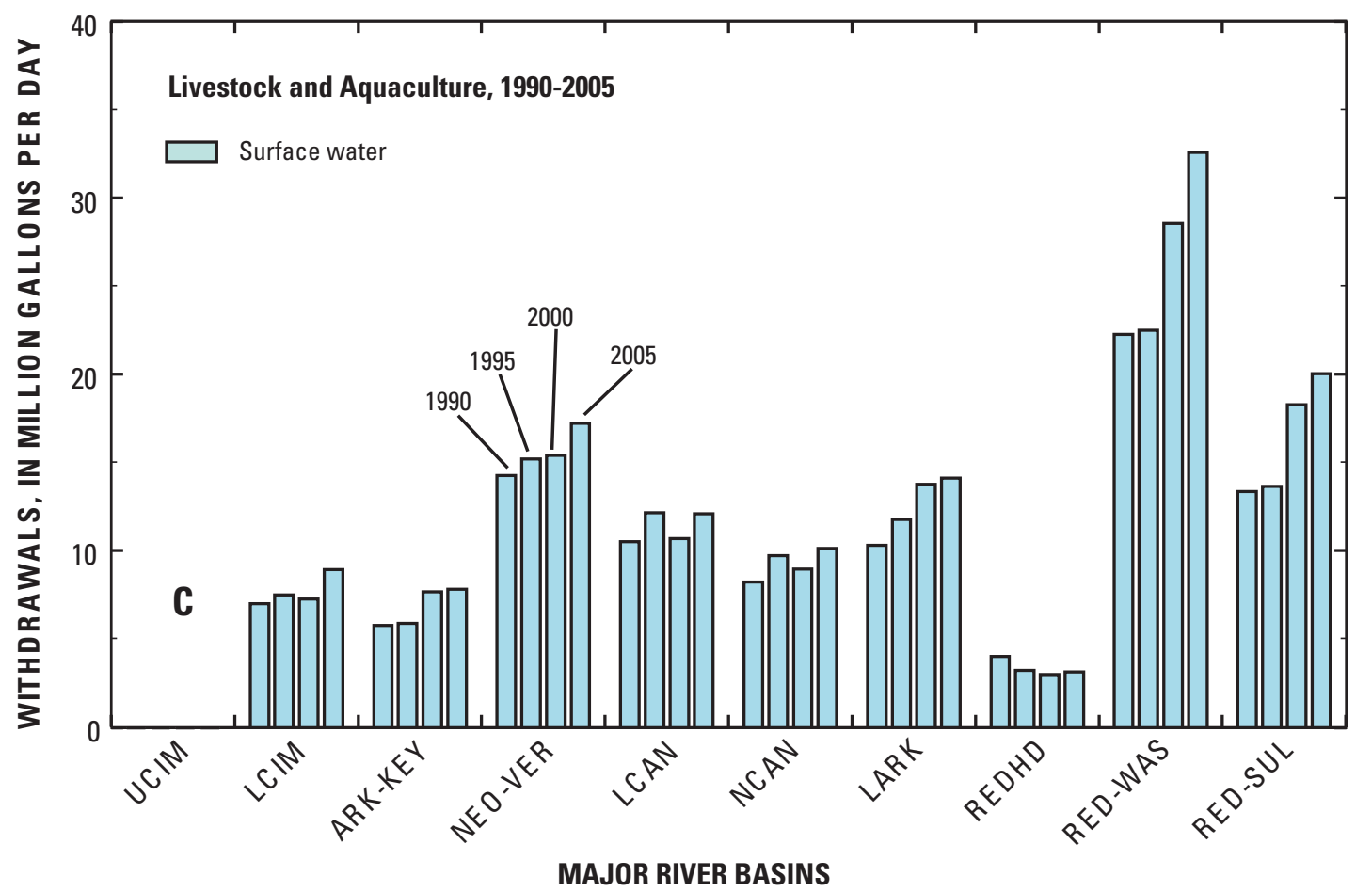

\begin{tabular}{|ll|}
\hline \multicolumn{2}{|c|}{ EXPLANATION } \\
UCIM & Upper Cimarron \\
LCIM & Lower Cimarron \\
ARK-KEY & Arkansas-Keystone \\
NEO-VER & Neosho-Verdigris \\
LCAN & Lower Canadian \\
NCAN & North Canadian \\
LARK & Lower Arkansas \\
REDHD & Red Headwaters \\
RED-WAS & Red-Washita \\
RED-SUL & Red-Sulphur \\
& \\
\hline
\end{tabular}

Figure 15. (A) Public supply surface-water withdrawals by major river basin in Oklahoma, 1990-2005 (B) Irrigation surface-water withdrawals by major river basin in Oklahoma, 1990-2005 (C) Livestock and aquaculture surface-water withdrawals by major river basin in 0klahoma, 1990-2005.-Continued 

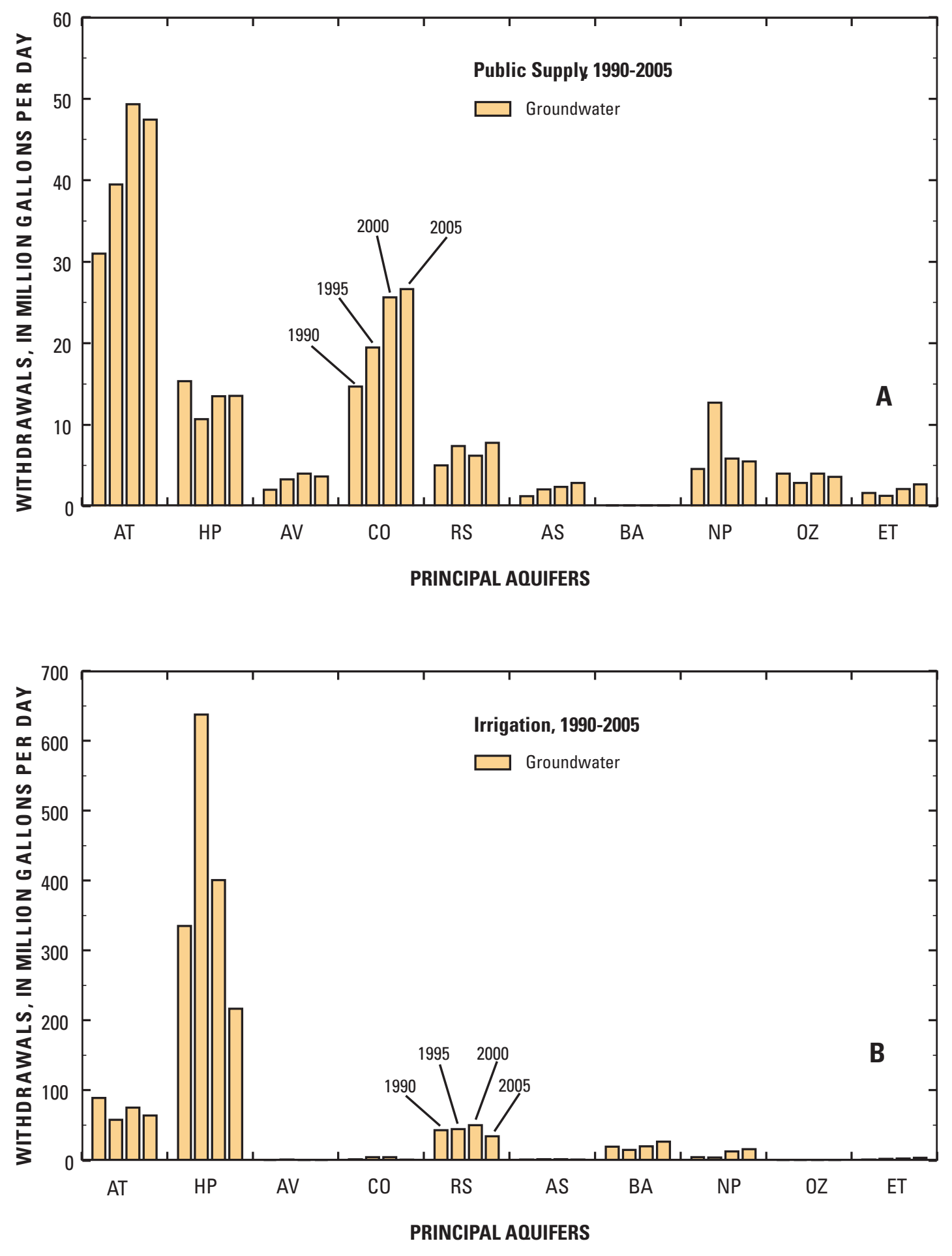

Figure 16. (A) Public supply groundwater withdrawals by principal aquifer in Oklahoma, 1990-2005 (B) Irrigation groundwater withdrawals by principal aquifer in Oklahoma, 1990-2005 (C) Livestock and aquaculture groundwater withdrawals by principal aquifer in Oklahoma, 1990-2005. 


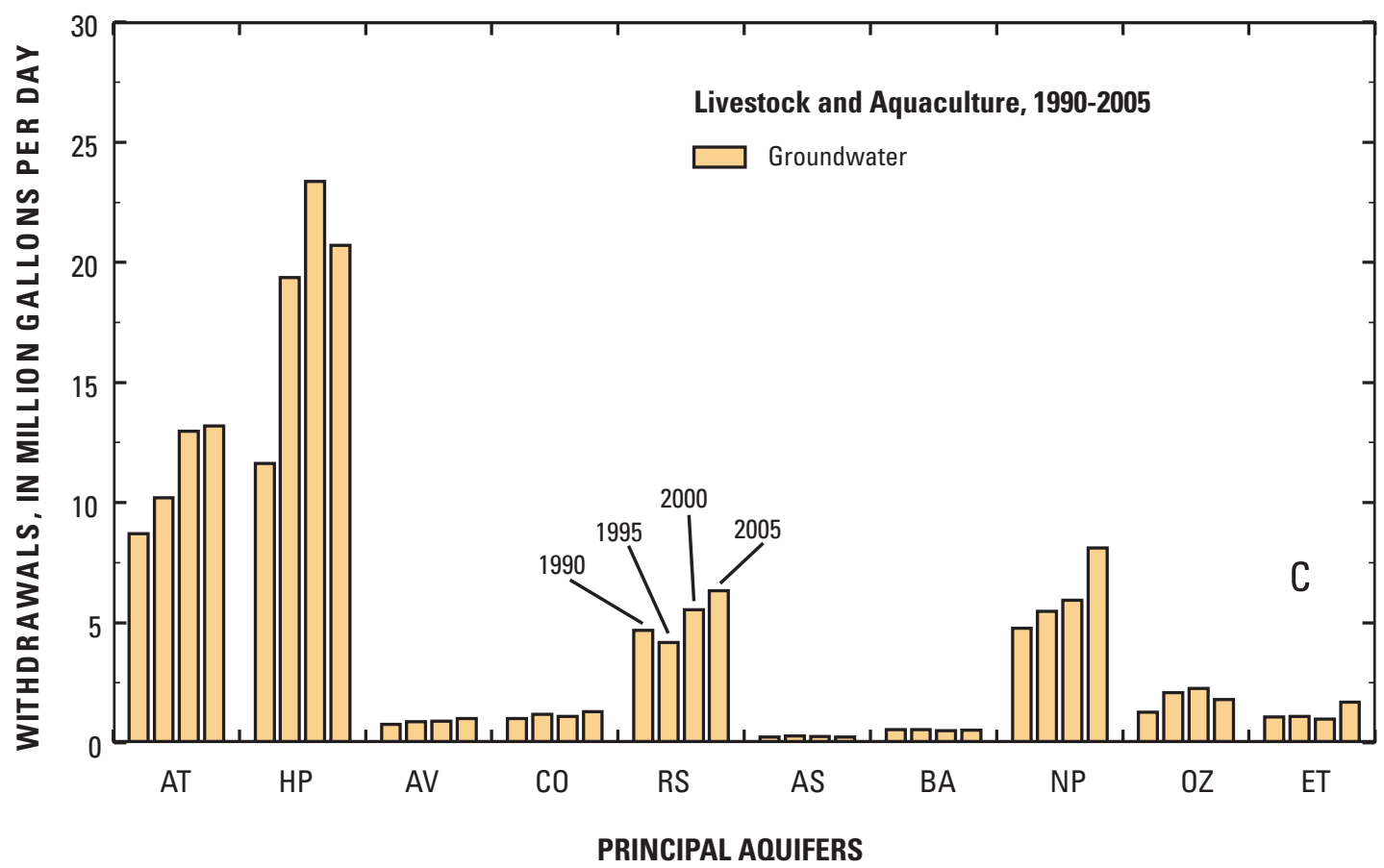

\begin{tabular}{|ll|}
\hline & EXPLANATION \\
AT & Alluvial and terrace \\
HP & High Plains \\
AV & Ada-Vamoosa \\
CO & Central Oklahoma \\
RS & Rush Springs \\
AS & Arbuckle-Simpson \\
BA & Blaine \\
NP & Not a Principal Aquifer \\
OZ & Ozark Plateaus \\
ET & Edwards-Trinity (Antlers) \\
\hline
\end{tabular}

Figure 16. (A) Public supply groundwater withdrawals by principal aquifer in Oklahoma, 1990-2005 (B) Irrigation groundwater withdrawals by principal aquifer in Oklahoma, 1990-2005 (C) Livestock and aquaculture groundwater withdrawals by principal aquifer in Oklahoma, 1990-2005. - Continued 
from 1995-2005 in the other principal aquifers. Irrigation water withdrawals depend on application method, crop type, acreage irrigated, seasonal climate, and economics. Panhandle groundwater irrigated acreage in 2005 was about 80 percent of the acreage in 1995, but irrigation water withdrawals in 2005 decreased to about 35 percent of 1995 withdrawals. This irrigation water withdrawal translates to an application rate that was less than half of what it was in 1995 (from 2.93 to 1.32 acre-feet per acre). The two main crops in the panhandle were corn and wheat; irrigated corn acreage remained about the same while most of reduction in irrigated acreage was in irrigated wheat acreage; rainfall in the panhandle was about normal during all three periods. This decrease in water withdrawn from the High Plains Aquifer likely indicated increased efficiency in irrigation water application methods in the panhandle.

Livestock and aquaculture groundwater withdrawals increased steadily from 1990-2000 and then decreased slightly in 2005 in the principal aquifer with the largest withdrawals - the High Plains Aquifer - mainly because of changes in the number of cattle and hogs in the panhandle counties (figs. 11 and 16C). Livestock withdrawals increased steadily from 1990-2005 in the principal aquifer with the next largest withdrawals - the alluvial and terrace aquifer (figs. 11 and 16C).

\section{Comparison of Water Use 1950-2005}

Freshwater withdrawals for water use are compared graphically in this section in 5-year intervals from 1950-2005 for (1) total withdrawals by source and total population, and (2) total withdrawals and withdrawals by category.

Surface-water sources have been generally increasing in importance (fig. 17), in part because of the increasing usage of surface water for public supply (fig. 12A) at the same time that the total population of Oklahoma and population served by surface-water sources increased (fig. 12B). The population spikes in 1975 and 1985 in off-census years were because of overly ambitious estimates (fig. 17; Murray and Reeves, 1977; Solley, Merk, and Pierce, 1988). Self-supplied or rural domestic water use was combined with livestock water use in early years, so for consistency these categories were combined for all years (fig. 18). Livestock withdrawals have been steadily increasing (figs. 14A and 18) and most of that water was surface water, in part because of the inclusion of aquaculture in the category (fig. 14A). Cooling water use for thermoelectric power generation also has risen steadily in since 1990 (figs. 14B and 18) and was almost entirely from surface-water sources (1990-2005 Oklahoma AWUDS tables). Large surface-water withdrawals in 1965 were mainly because of extraordinarily large withdrawals for thermoelectric cooling water, more than $300 \mathrm{Mgal} / \mathrm{d}$ more than in 1960 and 1970 (figs. 17 and 18) (Murray, 1968). Large surface-water withdrawals in 1975 were in large part because of industrial withdrawals, almost $200 \mathrm{Mgal} / \mathrm{d}$ more than 1970 (Murray and
Reeves, 1977), possibly illustrating the variability because of type of industry.

Groundwater sources have been generally decreasing in importance as a percentage of total withdrawals in recent years (fig. 17). However, the magnitude of groundwater withdrawals was greatly dependent on irrigation withdrawals and specifically irrigated acreage in the panhandle. A great many large-capacity irrigation wells were developed in the panhandle, most of which were drilled in 1965-80 (Wahl and Tortorelli, 1997). In the years that the number of irrigated acreage exceeded 560,000 acres (1970-80 and 1995), total groundwater withdrawals were greater than total surface-water withdrawals. Irrigation withdrawals are varied because these withdrawals are highly dependent on such factors as application method, crop type, acreage irrigated, seasonal climate, and economics such as crop prices, depth to water, and power costs.

\section{Summary}

Comprehensive planning for water resources development and use in Oklahoma requires a historical perspective on water resources. This report presents 1950-2005 freshwater withdrawal estimates for Oklahoma by source and category in 5 -year intervals. Withdrawal source was either surface water or groundwater. Withdrawal categories include: public supply, irrigation, livestock and aquaculture, thermoelectric power generation, domestic and commercial, and industrial and mining. Withdrawal data were aggregated and tabulated by county, principal river basin, and major aquifer.

The purpose of this report is to summarize water-use data in Oklahoma through: (1) presentation of detailed information on freshwater withdrawals by source, county, major river basin, and major aquifer for 2005; (2) comparison of water use by source, major category, major river basin, and major aquifer at 5-year intervals from 1990-2005; and (3) comparison of water use on a statewide basis by source and category at 5-year intervals from 1950-2005.

Total withdrawals from surface-water and groundwater sources during 2005 were 1,559 million gallons per day—989 million gallons per day or 63 percent from surface-water sources and 570 million gallons per day or 37 percent from groundwater sources. The three largest water-use categories were public supply, 646 million gallons per day or 41 percent of total withdrawals; irrigation, 495 million gallons per day or 32 percent of total withdrawals; and livestock and aquaculture, 181 million gallons per day or 12 percent of total withdrawals. All other categories were 237 million gallons per day or 15 percent of total withdrawals.

The influence of public supply on the total withdrawals can be seen in the eastern two-thirds of Oklahoma; whereas, the influence of irrigation on total withdrawals can be seen in the western third of Oklahoma. Surface-water sources were 


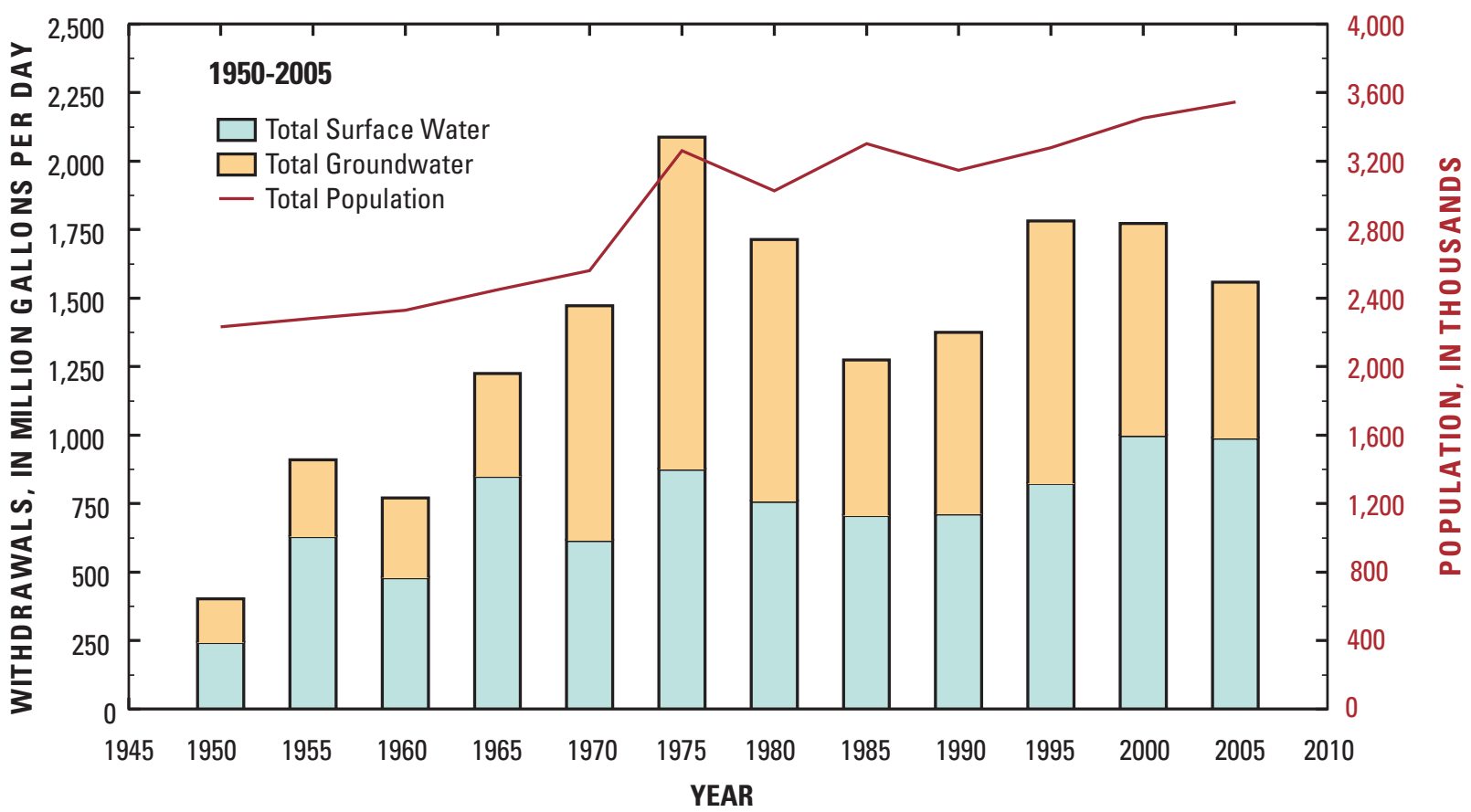

Figure 17. Freshwater withdrawals by source and population in Oklahoma, 1950-2005.

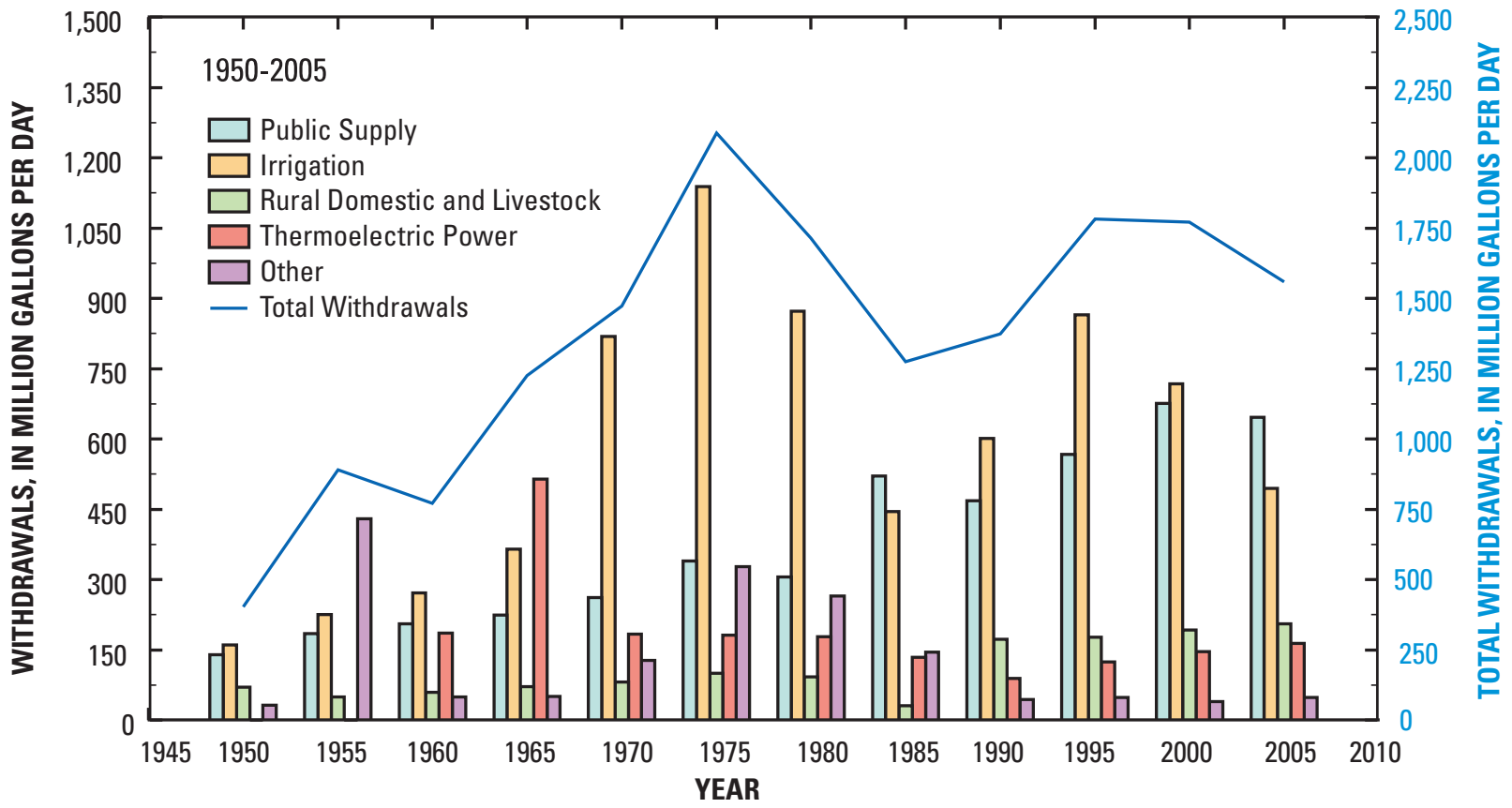

Figure 18. Freshwater withdrawals by category in Oklahoma, 1950-2005. 
dominant in the eastern half of Oklahoma and groundwater sources were dominant in the western half of Oklahoma.

Public supply was the largest category of surface-water withdrawals in 6 of the 10 major river basins in 2005: North Canadian, Arkansas-Keystone, Neosho-Verdigris, RedSulphur, Lower Canadian, and Red-Washita River basins. Irrigation was the largest category of surface-water withdrawals only in the western one-third of Oklahoma in two basins: the Upper Cimarron River Basin; and Red Headwaters River Basin, which supplies the Altus-Lugert Irrigation District. Livestock and aquaculture surface-water withdrawals were about one-fifth or more of the withdrawals in half of the major river basins: Lower Cimarron, Arkansas-Keystone, RedSulphur, Lower Canadian, and Red-Washita River basins. Cooling water withdrawals for thermoelectric power generation were the largest withdrawals in the other category in two major river basins in eastern Oklahoma: Neosho-Verdigris and Lower Arkansas River basins.

Public supply groundwater withdrawals in 2005 were 30 percent or more of the withdrawals in more than half of principal aquifers: Alluvial and terrace, Central Oklahoma, Ada-Vamoosa, Ozark Plateaus, Edwards-Trinity, and Arbuckle-Simpson aquifers. Irrigation was the largest category of groundwater withdrawals for more than half of the aquifers: High Plains, alluvial and terrace, Edwards-Trinity, Not Principal, Rush Springs, and Blaine aquifers. Livestock and aquaculture groundwater withdrawals were a large volume of withdrawals in the northwest with two aquifers, High Plains and alluvial and terrace aquifers.

Public supply withdrawals increased steadily from 19902000 and then decreased slightly in 2005, mainly because of a decrease in surface-water withdrawals. The total population of the state and the population served by public-supplied surface water have increased steadily; whereas, the population served by public-supplied groundwater has remained about the same, and the self-supplied population has steadily decreased.

Irrigation withdrawals increased from 1990-1995 and then decreased steadily to 2005, mainly because of irrigation in the panhandle (Cimarron, Texas, and Beaver Counties). Irrigation water withdrawals depend on application method, crop type, acreage irrigated, seasonal climate, and economics. Panhandle groundwater irrigated acreage in 2005 was about 80 percent of the acreage in 1995, but irrigation water withdrawals in 2005 decreased to about 36 percent of 1995 withdrawals.

Total livestock and aquaculture withdrawals steadily increased from 1990-2005. Cattle numbers have remained about the same from 1990-2005. However, hogs have increased 10 fold and broiler chickens have almost doubled from 1990-2005, resulting in increased water withdrawals for these livestock. Surface-water withdrawals have remained about the same, but groundwater withdrawals for livestock have increased by 55 percent from 1990-2005. The largest increase in the other categories was thermoelectric power generation, which has steadily increased and almost doubled from 1990-2005.

Surface-water sources have been increasing in importance from 1950-2005, in part because of the increasing usage of surface-water for public supply at the same time that the total population of Oklahoma and population served by surface-water sources increased. Water withdrawals for livestock have been steadily increasing and most of that water was surface-water withdrawals, in part because of the inclusion of aquaculture. Cooling water for thermoelectric power generation also has risen steadily since 1990 and was almost entirely from surface-water sources.

Groundwater sources have been generally decreasing in importance as a percentage of total withdrawals in recent years. However, the magnitude of groundwater withdrawals is greatly dependent on irrigation withdrawals and specifically, irrigated acreage in the panhandle. Irrigation withdrawals are varied because these withdrawals are highly dependent on such factors as application method, crop type, acreage irrigated, seasonal climate, and economics such as crop prices, depth to water, and power costs.

\section{Selected References}

Bureau of Reclamation, 2007, Oklahoma Facilities, Web page at http://www.usbr.gov/projects/FacilitiesByState. jsp? StateID=OK. (Accessed March 14, 2007.)

Dziegielewski, Benedykt, Subhash, C.S., Bik, T.J., Margono, Heru, and Yang, Xiaoying, 2002, Analysis of water use trends in the United States-1950-1995: Project Completion Report, Southern Illinois University, Carbondale, Ill. variously paged.

Grand River Dam Authority, 2007, Facilities: Available online at http://www.grda.com/. (Accessed May 10, 2007.)

Gurdak, J.J., McMahon, P.B., Dennehy, K.F., and Qi, S.L., 2009, Water quality in the High Plains aquifer, Colorado, Kansas, Nebraska, New Mexico, Oklahoma, South Dakota, Texas, and Wyoming, 1999-2004: U.S. Geological Survey Circular 1337, 63 p.

Hobbs, Frank, and Stoops, Nicole, 2002, U.S. Department of Commerce, U.S. Census Bureau, Census 2000 Special Reports, Series CENSR-4, Demographic trends in the 20th Century: U.S. Government Printing Office, Washington D.C., p. 143. Available at http://www.census.gov/ prod/2002pubs/censr-4.pdf. (Accessed December 18, 2003)

Holland, T.W., 2007, Water use in Arkansas, 2005: U.S. Geological Survey Scientific Investigations Report 2007-5241, $32 \mathrm{p}$. 
Hutson, S.S., compiler, 2007, Guidelines for preparation of State water-use estimates for 2005: U.S. Geological Survey Techniques and Methods Book 4, Chap. E1, 28 p. Available online at $\mathrm{http}: / / \mathrm{pubs}$.usgs.gov/tm/2007/tm4e1/pdf/tm4-e1. $p d f$.

Hutson, S.S., Barber, N.L., Kenny, J.F., Linsey, K.S., Lumia, D.S., and Maupin, M.A., 2004, Estimated use of water in the United States in 2000: U.S. Geological Survey Circular $1268,46 \mathrm{p}$.

Kenny, J.F., and Hansen, C.V., 2004, Water use in Kansas, 1990-2000: U.S. Geological Survey Fact Sheet 2004-3133, $4 \mathrm{p}$.

Kenny, J.F., Barber, N.L., Hutson, S.S., Linsey, K.S., Lovelace, J.K., and Maupin, M.A., 2009, Estimated use of water in the United States in 2005: U.S. Geological Survey Circular 1344, $52 \mathrm{p}$.

Lurry, D.L., and Tortorelli, R.L., 1996, Estimated freshwater withdrawals in Oklahoma, 1990: U.S. Geological Survey Water-Resources Investigations Report 95-4276, 2 sheets.

MacKichan, K.A., 1951, Estimated use of water in the United States, 1950: U.S. Geological Survey Circular 115, 13 p.

MacKichan, K.A., 1957, Estimated use of water in the United States, 1955: U.S. Geological Survey Circular 398, 18 p.

MacKichan, K.A., and Kammerer, J.C., 1961, Estimated use of water in the United States, 1960: U.S. Geological Survey Circular 456, $44 \mathrm{p}$.

Maupin, M.A., and Barber, N.L., 2005, Estimated withdrawals from principal aquifers in the United States, 2000: U.S. Geological Survey Circular 1279, 46 p.

Murray, C.R., 1968, Estimated use of water in the United States, 1965: U.S. Geological Survey Circular 556, 53 p.

Murray, C.R., and Reeves, E.B., 1972, Estimated use of water in the United States, 1970: U.S. Geological Survey Circular $676,37 \mathrm{p}$.

Murray, C.R., and Reeves, E.B., 1977, Estimated use of water in the United States, 1975: U.S. Geological Survey Circular $765,37 \mathrm{p}$.

National Agricultural Statistics Service, 2006, Oklahoma County data 2006-Livestock: Available online at http:// www.nass.usda.gov/Statistics_by_State/Oklahoma/index. asp. (Accessed August 28, 2008.)

National Agricultural Statistics Service, 2007, 2002 Census of agriculture - County data, irrigation: Oklahoma: Available online at http://www.agcensus.usda.gov/Publications/2002/ Volume_1,_Chapter_2_County_Level/Oklahoma/index.asp. (Accessed June 9, 2009.)
National Climatic Data Center, 2008, Climate Visualization System: Available online at http://www7.ncdc.noaa.gov/ CDO/CDODivisionalSelect.jsp. (Accessed May 31, 2008.)

Natural Resources Conservation Service, 1998, Irrigation guide, Oklahoma Supplement, Chapter 4-Water requirements: National Engineering Handbook-Part 652, Notice $\mathrm{OK}-1,23 \mathrm{p}$.

Oklahoma Climatological Survey, 2008a, Rainfall statistics: Available online at http://climate.mesonet.org/ rainfall/2000summer.php.html. (Accessed September 25, 2008.)

Oklahoma Climatological Survey, 2008b, Rainfall statistics: Available online at http://climate.mesonet.org/ rainfall/2005summer.php.html. (Accessed September 25, 2008.)

Oklahoma Department of Agriculture, 1991, Oklahoma Agricultural Statistics 1990, 103 p.

Oklahoma Department of Agriculture, 1996, Oklahoma Agricultural Statistics 1995, 104 p.

Oklahoma Department of Agriculture, 2001, Oklahoma Agricultural Statistics 2000, $104 \mathrm{p}$.

Oklahoma Department of Agriculture, 2006, Oklahoma Agricultural Statistics 2006, $107 \mathrm{p}$.

Oklahoma Department of Environmental Quality, 2008, Drinking Water Branch, Drinking Water Supply System Data: Web page at http://sdwis.deq.state.ok.us/. (Accessed August 22, 2008.)

Oklahoma Water Resources Board, 1990, Oklahoma Water Atlas, Publication 135, 360 p.

Oklahoma Water Resources Board, 1998, Rural Water Systems in Oklahoma, Publication 138, 212 p.

Perlman, H.A., 1998, User's manual for the National Water Information System of the U.S. Geological Survey, Chapter 4, Water-Use Data System, Part 2, Aggregate Water-Use Data System: U.S. Geological Survey Open-File Report 98-575, $33 \mathrm{p}$.

Ryder, Paul D., 1996, Ground Water Atlas of the United States: Segment 4, Oklahoma, Texas: U.S. Geological Survey Hydrologic Atlas 730-E, $30 \mathrm{p}$.

Schein, Gary, 2008, Stimulation for shale resources plays: Energy Institute Resource Workshop, January 14-15, 2008, Texas Christian University, Fort Worth, Texas.

Solley, W.B., Chase, E.B., and Mann, W.B., IV, 1983, Estimated use of water in the United States in 1980: U.S. Geological Survey Circular 1001, 56 p. 
Solley, W.B., Merk, C.F., and Pierce, R.R., 1988, Estimated use of water in the United States in 1985: U.S. Geological Survey Circular 1004, 82 p.

Solley, W.B., Pierce, R.R., and Perlman, H.A., 1993, Estimated use of water in the United States in 1990: U.S. Geological Survey Circular 1081, 76 p.

Solley, W.B., Pierce, R.R., and Perlman, H.A., 1998, Estimated use of water in the United States in 1995: U.S. Geological Survey Circular 1200, $71 \mathrm{p}$.

Southwestern Power Administration, 2007, 2004-2006 Annual report: Southwestern Power Administration, 32 p. Available at $h t t p: / / w w w . s w p a . g o v / P D F s / S W P A+F Y 2004-2006$ annual_report.pdf. (Accessed October 17, 2008.)

Tortorelli, R.L., 2002, Statistical summaries of streamflow in Oklahoma through 1999: U.S. Geological Survey WaterResources Investigations Report 02-4025, 510 p.

Tortorelli, R.L., 2008, Hydrologic drought of Water Year 2006 compared with four major drought periods of the 20th century in Oklahoma: U.S. Geological Survey Scientific Investigations Report 2008-5199, 46 p.

Tortorelli, R.L., and McCabe, L.P., 2001, Flood frequency estimates and documented and potential extreme peak discharges in Oklahoma: U.S. Geological Survey Water-
Resources Investigations Report 01-4152, 59 p.

Tortorelli, R.L., Rasmussen, T.J., and Perry, C.A., 2005, Trends in annual peak flows and mean annual flows of selected streams within and near Oklahoma: U.S. Geological Survey Scientific Investigations Report 2005-5192, 116 p.

Tortorelli, R.L., Rea, Alan, and Asquith, W.H., 1999, Depthduration frequency of precipitation for Oklahoma: U.S. Geological Survey Water-Resources Investigations Report 99-4232, $113 \mathrm{p}$.

U.S. Army Corps of Engineers, 2007, Tulsa District water control home page: Available at http://www.swt-wc.usace. army.mil/. (Accessed March 13, 2007.)

U.S. Department of Energy, 2006, Electric power annual, 2005: Washington, D.C., Energy Information Administration, $88 \mathrm{p}$.

U.S. Geological Survey, 2008, Water use in the United States: Available online at http://water.usgs.gov/watuse/. (Accessed September 1, 2008.)

Wahl, K.L., and Tortorelli, R.L., 1997, Changes in flow in the Beaver-North Canadian River Basin upstream from Canton Lake, western Oklahoma: U.S. Geological Survey WaterResources Investigations Report 96-4304, 58 p. 


\section{Appendixes}


Water Use in Oklahoma 1950-2005 


\section{Glossary}

Water-use terminology has changed in the series of USGS water-use Circulars prepared at 5-year intervals. The term water use as initially used for 1950 in the USGS water-use Circulars meant withdrawals of water; in the report for 1960 , the term was redefined to include consumptive use of water and withdrawals. With the beginning of the USGS National Water Use Information Program in 1978, the term was again redefined to include return flow and offstream and instream uses. The term was redefined in the report for 1985 to include withdrawals plus deliveries from public suppliers. In the water-use Circular for 2000, water use is defined as initially used in 1950 as withdrawals of water. The following terms are referenced in the text and are part of the water-use Circular series (modified from Kenny and others, 2009). These data for 1985-2005 can be accessed at the USGS water use web site at http://water.usgs.gov/watuse/wudata.html.

\section{A}

animal-specialties water use - water use associated with the production of fish in captivity, except for fish hatcheries, and the raising of horses and such fur-bearing animals as rabbits and pets. Animal-specialties water-use estimates were included in the 1990 and 1995 water-use Circulars, but were combined with the livestock categories or aquaculture categories for 2000 and 2005. See also aquaculture water use, fish-farm water use, livestock water use, and rural water use.

aquaculture water use - water use associated with the farming of organisms that live in water-such as finfish and shellfish - and offstream water use associated with fish hatcheries. See also fish-hatchery water use, animal-specialties water use, and livestock water use.

\section{C}

closed-loop cooling system — See recirculation cooling system.

commercial water use - water for motels, hotels, restaurants, office buildings, other commercial businesses, military and nonmilitary institutions, and (for 1990 and 1995) offstream fish hatcheries. Water may be obtained from a public-supply system or may be self-supplied. Commercial water-use estimates were included in some previous water-use Circulars but were omitted beginning in 2000. In Oklahoma water-use estimates for 1990-2005, commercial water use category was included and refers only to self-supplied commercial withdrawals. Most commercial use in Oklahoma is included in and delivered from public supply. See also fish-hatchery water use, public-supply water use, public-supply deliveries, and selfsupplied water use. consumptive use - the part of water withdrawn that is evaporated, transpired, incorporated into products or crops, consumed by humans or livestock, or otherwise removed from the immediate water environment. Consumptive-use estimates were included in some previous water-use Circulars but were omitted beginning in 2000 . However, these estimates were included for all Oklahoma water-use estimates for 1990-2005. Also referred to as water consumed.

conveyance loss - water that is lost in transit from a pipe, canal, conduit, or ditch by leakage or evaporation. Generally, the water is not available for further use; however, leakage from an irrigation ditch, for example, may percolate to a groundwater source and be available for further use. Conveyance-loss estimates were included in some previous water-use Circulars but were omitted beginning in 2000. However, these estimates were included for all Oklahoma water-use estimates for 1990-2005. See also irrigation water use.

cooling system - an equipment system that provides water for cooling, such as to condensers at power plants or at factories. May include water intakes, outlets, cooling towers, ponds, canals, pumps, and pipes. See also cooling-system type, industrial water use, and thermoelectric-power water use.

cooling-system type-See once-through cooling system and recirculation cooling system.

D

domestic water use - water used for indoor household activities such as drinking, food preparation, bathing, washing clothes and dishes, flushing toilets, and outdoor uses such as watering lawns and gardens. Domestic water use includes water provided to households by a public-water supply (domestic deliveries) and self-supplied water. In Oklahoma water-use estimates for 1990-2005, domestic water use category refers only to self-supplied domestic withdrawals and is assumed to be totally from groundwater withdrawals. See also publicsupply deliveries, public-supply water use, rural water use, and self-supplied water use.

\section{$\mathbf{F}$}

fish-hatchery water use - water used for raising fish for later release and in association with the operation of fish hatcheries or fishing preserves. Fish-hatchery water use has been included in the aquaculture category since 2000. See also aquaculture water use, commercial water use.

freshwater-water that contains less than 1,000 milligrams per liter (mg/L) of dissolved solids; generally, more than 500 $\mathrm{mg} / \mathrm{L}$ of dissolved solids is undesirable for drinking and for many industrial uses. However, Oklahoma has an exception. Water withdrawn from the Blaine aquifer often exceeds 1,000 
$\mathrm{mg} / \mathrm{L}$ and is used predominantly for irrigation (Lurry and Tortorelli, 1996). See also saline water.

\section{I}

industrial water use - water used for fabrication, processing, washing, and cooling. Includes industries such as chemical and allied products, food, mining, paper and allied products, petroleum refining, and steel. Term used in previous water-use Circulars to describe the combined public-supply deliveries to industrial users and self-supplied industrial withdrawals. For 2000 and 2005, industrial water use refers only to self-supplied industrial withdrawals. In Oklahoma water-use estimates for 1990-2005, most of the industrial use in Oklahoma is included in and delivered from public supply; industrial wateruse category refers only to self-supplied industrial withdrawals. See also cooling system, cooling-system type, mining water use, public-supply deliveries, public-supply water use, self-supplied water use, and thermoelectric-power water use.

instream use - water that is used, but not withdrawn, from a surface-water source such as hydroelectric power generation, navigation, water-quality improvement, fish propagation, and recreation. Instream water-use estimates for hydroelectric power were included in previous water-use Circulars but were omitted for 2000 and 2005; but were included for all Oklahoma water-use estimates for 1950-2005.

irrigation district - a cooperative, self-governing public corporation set up as a subdivision of the State government, with definite geographic boundaries, organized, and having taxing power to obtain and distribute water for irrigation of lands in the district; created under the authority of a State legislature with the consent of a designated fraction of the landowners or citizens. See also irrigation water use.

irrigation water use - water that is applied by an irrigation system to assist crop and pasture growth, or to maintain vegetation on recreational lands such as parks and golf courses. Irrigation includes water that is applied for pre-irrigation, frost protection, chemical application, weed control, field preparation, crop cooling, harvesting, dust suppression, leaching of salts from the root zone, and conveyance losses. Oklahoma water-use estimates for 1990-2005 included only crop irrigation. Parks and golf courses are included in the commercial category for this report, usually delivered by public supply. See also conveyance loss, micro-irrigation system, sprinkler irrigation system, and surface irrigation system.

\section{$\mathbf{L}$}

livestock water use - water used for livestock watering, feedlots, dairy operations, and other on-farm needs. Types of livestock include dairy cows and heifers, beef cattle and calves, sheep and lambs, goats, hogs and pigs, horses, and poultry. See also animal-specialties water use, aquaculture water use, and rural water use.
M

micro-irrigation system - an irrigation system that wets only a discrete part of the soil surface near the plant by means of applicators (such as orifices, emitters, porous tubing, or perforated pipe) and operated under low pressure. The applicators may be placed on or below the land surface or suspended from supports. See also irrigation water use, sprinkler irrigation system, and surface irrigation system.

mining water use - water used for the extraction of naturally occurring minerals including solids (such as coal, sand, gravel, and other ores), liquids (such as crude petroleum), and gases (such as natural gas). Also includes uses associated with quarrying, milling, and other preparations customarily done at the mine site or as part of a mining activity. Does not include water associated with dewatering of the aquifer that is not put to beneficial use. Also does not include water used in processing, such as smelting, refining petroleum, or slurry pipeline operations. These processing uses are included in industrial water use. Most of mining water use in Oklahoma is not freshwater withdrawals, but saltwater in conjunction with the petroleum industry. See also industrial water use and selfsupplied water use.

\section{0}

offstream use - water withdrawn or diverted from a groundwater or surface-water source for aquaculture, commercial, domestic self-supply, industrial, irrigation, livestock, mining, public supply, thermoelectric power, and other uses. See also entries for each of these categories of use.

once-through cooling system - also known as open-loop cooling system. Cooling system in which the water is withdrawn from a source, circulated through the heat exchangers, and then returned to a body of water at a higher temperature. See also cooling system, cooling system type, industrial water use, and thermoelectric-power water use.

\section{$\mathbf{P}$}

public-supply deliveries - amount of water delivered from a public supplier to users for domestic, commercial, industrial, thermoelectric power, or public water use. Estimates of deliveries for each purpose were provided for 1995 and earlier years, but not for 2000. For 2005, only domestic deliveries were estimated nationally. However these estimates were included for all Oklahoma water-use estimates for 1990-2005. See also commercial water use, domestic water use, industrial water use, public-supply water use, public-water use, andthermoelectric-power water use.

public-supply water use - water withdrawn by public- and private water suppliers that furnish water to groups of users. Public suppliers provide water for a variety of uses, such as domestic, commercial, industrial, thermoelectric power, and public water use. See also commercial water use, domestic water use, industrial water use, public-supply deliveries, 
public water use, and thermoelectric-power water use.

public water use - water supplied from a public supplier and used for firefighting, street washing, flushing of water lines, and maintaining municipal parks and swimming pools. Generally, public-use water is not billed by the public supplier. See also public-supply deliveries and public-supply water use.

\section{$\mathbf{R}$}

recirculation cooling system — also known as closed-loop cooling system. Water is withdrawn from a source, circulated through heat exchangers, cooled, and then re-used in the same process. Recirculation cooling systems may utilize induced draft cooling towers, forced draft cooling towers, cooling ponds, or canals. See also cooling system, cooling-system type, industrial water use, and thermoelectric-power water use.

reclaimed wastewater-wastewater treatment plant effluent that has been diverted for beneficial uses such as irrigation, industry, or thermoelectric cooling instead of being released to a natural waterway or aquifer. See also water use.

return flow - water that reaches a groundwater or surfacewater source after release from the point of use and thus becomes available for further use. Term used in previous water-use Circulars. See also water use.

rural water use - water used in suburban or farm areas for domestic and livestock needs. The water generally is self-supplied, and includes domestic use, drinking water for livestock, and other uses, such as dairy sanitation, cleaning, and waste disposal. Term used in previous water-use Circulars. Self-supplied domestic and livestock uses were included as separate categories for all Oklahoma water-use estimates for 19902005. See also animal-specialties water use, domestic water use, livestock water use, and self-supplied water use.

\section{S}

saline water-water that contains $1,000 \mathrm{mg} / \mathrm{L}$ or more of dissolved solids. See also freshwater.

self-supplied water use - water withdrawn from a groundwater or surface-water source by a user rather than being obtained from a public supply.

sprinkler irrigation system - An irrigation system in which water is applied by means of perforated pipes or nozzles operated under pressure so as to form a spray pattern. See also irrigation water use, micro-irrigation system, and surface irrigation system. surface irrigation system - irrigation by means of flood, furrow, or gravity. Flood irrigation is the application of irrigation water in which the soil surface is covered by ponded water. Furrow is a partial surface-flooding method of irrigation normally used with clean-tilled crops in which water is applied in furrows or rows of sufficient capacity to contain the design irrigation stream. Gravity is an irrigation method in which water is not pumped, but flows in ditches or pipes and is distributed by gravity. See also irrigation water use, microirrigation system, and sprinkler irrigation system.

T

thermoelectric-power water use - water used in the process of generating electricity with steam-driven turbine generators. Term used in previous water-use Circulars to describe the combined public-supply deliveries to thermoelectric-power plants and self-supplied thermoelectric-power withdrawals. For 2000 and 2005, thermoelectric-power water use refers only to self-supplied thermoelectric-power withdrawals. See also cooling system, cooling-system type, public-supply water use, and self-supplied water use.

\section{W}

wastewater-treatment return flow - term used in previous water-use Circulars to describe water returned to the hydrologic system by wastewater-treatment facilities. See also water use

water use - (1) In a restrictive sense, the term refers to water that is withdrawn for a specific purpose, such as for public supply, domestic use, irrigation, thermoelectric-power cooling, or industrial processing. In previous water-use Circulars, water use for the domestic, commercial, industrial, and thermoelectric categories included self-supplied withdrawals and deliveries from public supply. (2) More broadly, water use pertains to the interaction of humans with and influence on the hydrologic cycle, and includes elements such as water withdrawal, delivery, consumptive use, wastewater release, reclaimed wastewater, return flow, and instream use. See also offstream use and instream use.

watt-hour (Wh) - an electrical energy unit of measure equal to 1 watt of power supplied to, or taken from, an electric circuit steadily for 1 hour.

water withdrawal - water removed from the ground or diverted from a surface-water source for use. See also offstream use and self-supplied water use. 
Appendix 1. Estimated total freshwater withdrawals by county, use, and source in Oklahoma, 2005.

[Amounts are in million gallons per day. Totals may not add to totals because of independent rounding. Source: Oklahoma AWUDS database 2005 county aggregation. County aggregation may not match major river basin and principal aquifer aggregation due to independent aggregation]

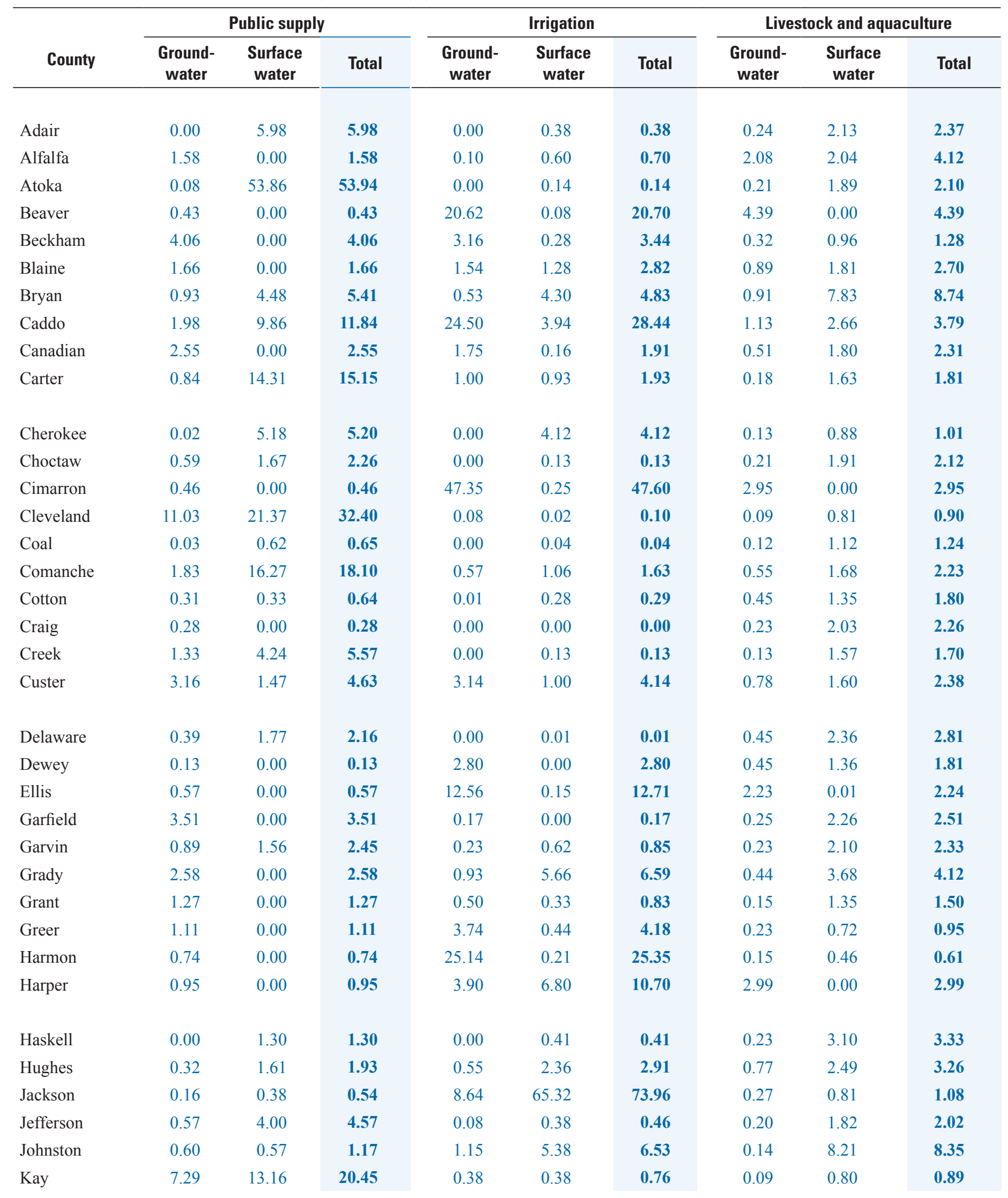


Appendix 1. Estimated total freshwater withdrawals by county, use, and source in Oklahoma, 2005. —Continued

[Amounts are in million gallons per day. Totals may not add to totals because of independent rounding. Source: Oklahoma AWUDS database 2005 county aggregation. County aggregation may not match major river basin and principal aquifer aggregation due to independent aggregation]

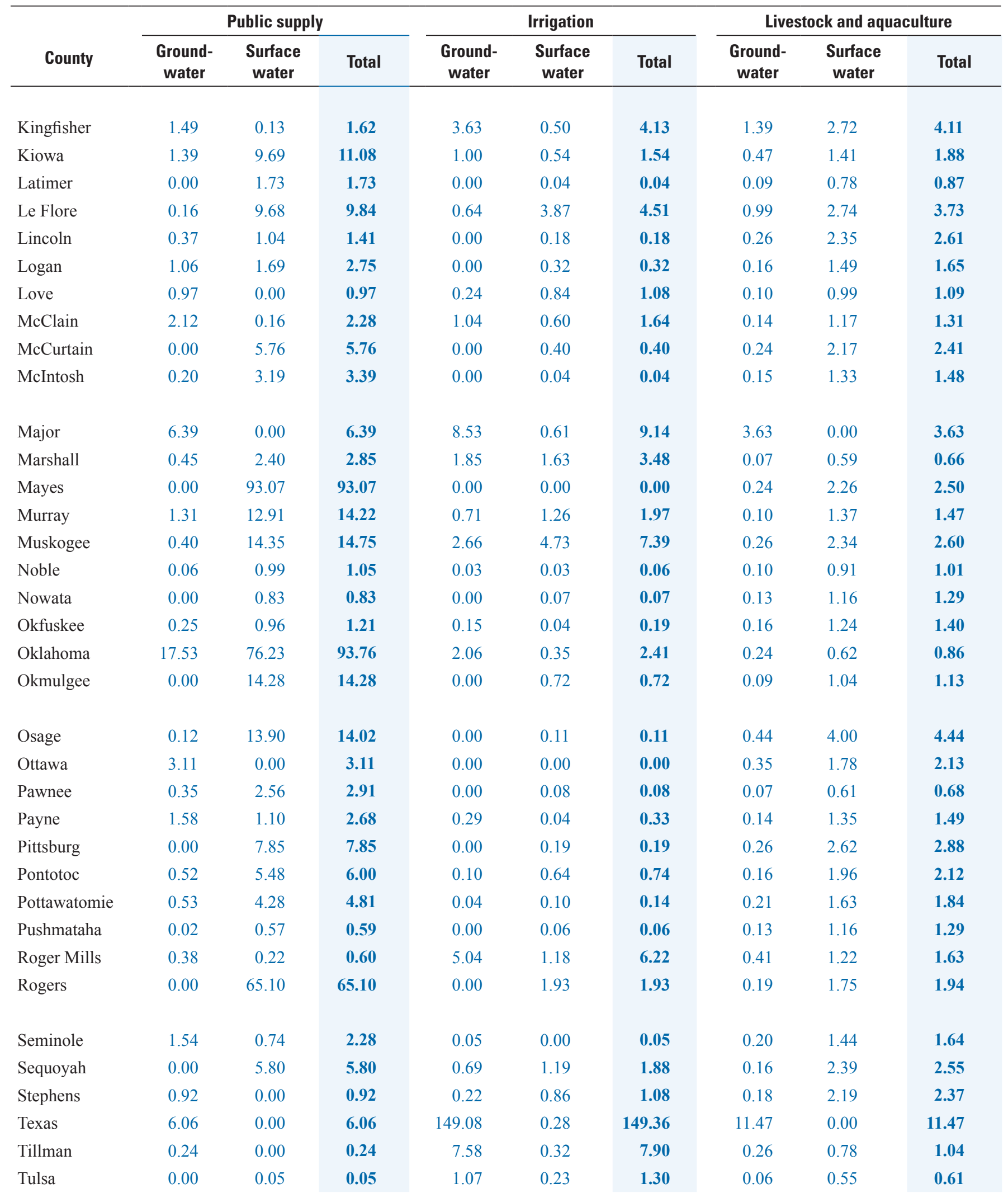


Appendix 1. Estimated total freshwater withdrawals by county, use, and source in Oklahoma, 2005. —Continued

[Amounts are in million gallons per day. Totals may not add to totals because of independent rounding. Source: Oklahoma AWUDS database 2005 county aggregation. County aggregation may not match major river basin and principal aquifer aggregation due to independent aggregation]

\begin{tabular}{|c|c|c|c|c|c|c|c|c|c|}
\hline County & \multicolumn{3}{|c|}{ Public supply } & \multicolumn{3}{|c|}{ Irrigation } & \multicolumn{3}{|c|}{ Livestock and aquaculture } \\
\hline Wagoner & 0.00 & 6.41 & 6.41 & 0.29 & 0.58 & 0.87 & 0.12 & 2.21 & 2.33 \\
\hline Washington & 0.00 & 3.93 & 3.93 & 0.00 & 0.00 & 0.00 & 0.09 & 0.79 & 0.88 \\
\hline Woods & 1.78 & 0.00 & 1.78 & 2.01 & 0.02 & 2.03 & 1.87 & 0.00 & 1.87 \\
\hline Woodward & 7.07 & 0.00 & 7.07 & 4.41 & 0.25 & 4.66 & 2.87 & 0.00 & 2.87 \\
\hline Totals & 113.67 & 532.49 & 646.16 & 361.39 & 133.50 & 494.89 & 54.92 & 125.86 & 180.78 \\
\hline
\end{tabular}


Appendix 1. Estimated total freshwater withdrawals by county, use, and source in Oklahoma, 2005. —Continued

[Amounts are in million gallons per day. Totals may not add to totals because of independent rounding. Source: Oklahoma AWUDS database 2005 county aggregation. County aggregation may not match major river basin and principal aquifer aggregation due to independent aggregation]

\begin{tabular}{|c|c|c|c|c|c|c|c|c|c|}
\hline \multirow[b]{2}{*}{ County } & \multicolumn{3}{|c|}{$\begin{array}{c}\text { Thermoelectric-power } \\
\text { generation }\end{array}$} & \multicolumn{3}{|c|}{$\begin{array}{l}\text { Domestic and } \\
\text { commercial }\end{array}$} & \multicolumn{3}{|c|}{$\begin{array}{l}\text { Industrial and } \\
\text { mining }\end{array}$} \\
\hline & $\begin{array}{l}\text { Ground- } \\
\text { water }\end{array}$ & $\begin{array}{c}\text { Surface } \\
\text { water }\end{array}$ & Total & $\begin{array}{c}\text { Ground- } \\
\text { water }\end{array}$ & $\begin{array}{c}\text { Surface } \\
\text { water }\end{array}$ & Total & $\begin{array}{c}\text { Ground- } \\
\text { water }\end{array}$ & $\begin{array}{c}\text { Surface } \\
\text { water }\end{array}$ & Total \\
\hline Adair & 0.00 & 0.00 & 0.00 & 0.78 & 0.09 & 0.87 & 0.00 & 0.00 & 0.00 \\
\hline Alfalfa & 0.00 & 0.00 & 0.00 & 0.07 & 0.00 & 0.07 & 0.00 & 0.00 & 0.00 \\
\hline Atoka & 0.00 & 0.00 & 0.00 & 0.26 & 0.01 & 0.27 & 0.00 & 0.00 & 0.00 \\
\hline Beaver & 0.00 & 0.00 & 0.00 & 0.22 & 0.00 & 0.22 & 0.32 & 0.00 & 0.32 \\
\hline Beckham & 0.00 & 0.00 & 0.00 & 0.32 & 0.00 & 0.32 & 0.00 & 0.00 & 0.00 \\
\hline Blaine & 0.00 & 0.00 & 0.00 & 0.24 & 0.79 & 1.03 & 0.29 & 0.00 & 0.29 \\
\hline Bryan & 0.00 & 0.00 & 0.00 & 0.24 & 0.00 & 0.24 & 0.00 & 0.99 & 0.99 \\
\hline Caddo & 0.19 & 5.44 & 5.63 & 1.30 & 0.06 & 1.36 & 0.00 & 0.00 & 0.00 \\
\hline Canadian & 0.22 & 0.00 & 0.22 & 1.07 & 0.01 & 1.08 & 0.17 & 0.00 & 0.17 \\
\hline Carter & 0.00 & 0.00 & 0.00 & 0.02 & 0.01 & 0.03 & 0.02 & 0.05 & 0.07 \\
\hline Cherokee & 0.00 & 0.00 & 0.00 & 0.63 & 0.03 & 0.66 & 0.00 & 0.00 & 0.00 \\
\hline Choctaw & 0.00 & 5.73 & 5.73 & 0.40 & 1.27 & 1.67 & 0.00 & 0.03 & 0.03 \\
\hline Cimarron & 0.00 & 0.00 & 0.00 & 0.10 & 0.00 & 0.10 & 0.00 & 0.00 & 0.00 \\
\hline Cleveland & 0.00 & 0.00 & 0.00 & 1.48 & 0.00 & 1.48 & 0.03 & 0.00 & 0.03 \\
\hline Coal & 0.00 & 0.00 & 0.00 & 0.13 & 0.00 & 0.13 & 0.00 & 0.00 & 0.00 \\
\hline Comanche & 0.00 & 0.00 & 0.00 & 0.81 & 0.34 & 1.15 & 0.17 & 0.20 & 0.37 \\
\hline Cotton & 0.00 & 0.00 & 0.00 & 0.00 & 0.00 & 0.00 & 0.00 & 0.00 & 0.00 \\
\hline Craig & 0.00 & 0.00 & 0.00 & 0.07 & 0.00 & 0.07 & 0.00 & 0.00 & 0.00 \\
\hline Creek & 0.00 & 0.00 & 0.00 & 0.60 & 0.00 & 0.60 & 0.00 & 0.00 & 0.00 \\
\hline Custer & 0.00 & 0.00 & 0.00 & 0.30 & 0.04 & 0.34 & 0.00 & 0.00 & 0.00 \\
\hline Delaware & 0.00 & 0.00 & 0.00 & 0.98 & 0.00 & 0.98 & 0.00 & 0.00 & 0.00 \\
\hline Dewey & 0.00 & 0.00 & 0.00 & 0.09 & 0.00 & 0.09 & 0.07 & 0.00 & 0.07 \\
\hline Ellis & 0.00 & 0.00 & 0.00 & 0.12 & 0.00 & 0.12 & 0.01 & 0.00 & 0.01 \\
\hline Garfield & 0.00 & 0.00 & 0.00 & 0.20 & 0.00 & 0.20 & 0.00 & 0.00 & 0.00 \\
\hline Garvin & 0.00 & 0.00 & 0.00 & 0.35 & 0.04 & 0.39 & 0.00 & 0.00 & 0.00 \\
\hline Grady & 0.00 & 0.00 & 0.00 & 1.34 & 0.28 & 1.62 & 0.02 & 0.00 & 0.02 \\
\hline Grant & 0.00 & 0.00 & 0.00 & 0.06 & 0.00 & 0.06 & 0.00 & 0.00 & 0.00 \\
\hline Greer & 0.00 & 0.00 & 0.00 & 0.00 & 0.00 & 0.00 & 0.00 & 0.00 & 0.00 \\
\hline Harmon & 0.00 & 0.00 & 0.00 & 0.00 & 0.00 & 0.00 & 0.00 & 0.00 & 0.00 \\
\hline Harper & 0.00 & 0.00 & 0.00 & 0.08 & 1.18 & 1.26 & 0.00 & 0.00 & 0.00 \\
\hline Haskell & 0.00 & 0.00 & 0.00 & 0.45 & 0.00 & 0.45 & 0.00 & 0.00 & 0.00 \\
\hline Hughes & 0.00 & 0.00 & 0.00 & 0.08 & 0.30 & 0.38 & 0.00 & 0.00 & 0.00 \\
\hline Jackson & 0.00 & 0.00 & 0.00 & 0.09 & 0.04 & 0.13 & 0.52 & 0.00 & 0.52 \\
\hline Jefferson & 0.00 & 0.00 & 0.00 & 0.01 & 0.00 & 0.01 & 0.00 & 0.00 & 0.00 \\
\hline Johnston & 0.00 & 0.00 & 0.00 & 0.01 & 0.00 & 0.01 & 0.07 & 0.06 & 0.13 \\
\hline
\end{tabular}


Appendix 1. Estimated total freshwater withdrawals by county, use, and source in Oklahoma, 2005. —Continued

[Amounts are in million gallons per day. Totals may not add to totals because of independent rounding. Source: Oklahoma AWUDS database 2005 county aggregation. County aggregation may not match major river basin and principal aquifer aggregation due to independent aggregation]

\begin{tabular}{|c|c|c|c|c|c|c|c|c|c|}
\hline \multirow[b]{2}{*}{ County } & \multicolumn{3}{|c|}{$\begin{array}{c}\text { Thermoelectric-power } \\
\text { generation }\end{array}$} & \multicolumn{3}{|c|}{$\begin{array}{l}\text { Domestic and } \\
\text { commercial }\end{array}$} & \multicolumn{3}{|c|}{$\begin{array}{l}\text { Industrial and } \\
\text { mining }\end{array}$} \\
\hline & $\begin{array}{c}\text { Ground- } \\
\text { water }\end{array}$ & $\begin{array}{c}\text { Surface } \\
\text { water }\end{array}$ & Total & $\begin{array}{c}\text { Ground- } \\
\text { water }\end{array}$ & $\begin{array}{c}\text { Surface } \\
\text { water }\end{array}$ & Total & $\begin{array}{l}\text { Ground- } \\
\text { water }\end{array}$ & $\begin{array}{c}\text { Surface } \\
\text { water }\end{array}$ & Total \\
\hline Kay & 0.00 & 0.00 & 0.00 & 0.19 & 0.00 & 0.19 & 3.70 & 0.37 & 4.07 \\
\hline Kingfisher & 0.00 & 0.00 & 0.00 & 0.38 & 0.00 & 0.38 & 0.07 & 0.00 & 0.07 \\
\hline Kiowa & 0.00 & 0.00 & 0.00 & 0.00 & 0.00 & 0.00 & 0.00 & 0.02 & 0.02 \\
\hline Latimer & 0.00 & 0.00 & 0.00 & 0.11 & 0.00 & 0.11 & 0.00 & 0.00 & 0.00 \\
\hline Le Flore & 0.00 & 3.14 & 3.14 & 0.54 & 0.00 & 0.54 & 0.00 & 0.00 & 0.00 \\
\hline Lincoln & 0.00 & 0.00 & 0.00 & 1.52 & 0.00 & 1.52 & 0.00 & 0.00 & 0.00 \\
\hline Logan & 0.00 & 0.00 & 0.00 & 0.96 & 0.00 & 0.96 & 0.02 & 0.34 & 0.36 \\
\hline Love & 0.00 & 0.00 & 0.00 & 0.10 & 0.00 & 0.10 & 0.00 & 0.52 & 0.52 \\
\hline McClain & 0.00 & 0.00 & 0.00 & 0.65 & 0.00 & 0.65 & 0.00 & 0.00 & 0.00 \\
\hline McCurtain & 0.00 & 0.00 & 0.00 & 0.64 & 0.00 & 0.64 & 0.00 & 0.64 & 0.64 \\
\hline McIntosh & 0.00 & 0.00 & 0.00 & 0.00 & 0.03 & 0.03 & 0.00 & 0.00 & 0.00 \\
\hline Major & 0.00 & 0.00 & 0.00 & 0.18 & 0.00 & 0.18 & 0.00 & 0.00 & 0.00 \\
\hline Marshall & 0.00 & 0.00 & 0.00 & 0.06 & 0.19 & 0.25 & 0.00 & 0.00 & 0.00 \\
\hline Mayes & 0.00 & 11.62 & 11.62 & 0.00 & 0.00 & 0.00 & 0.00 & 0.00 & 0.00 \\
\hline Murray & 0.00 & 0.00 & 0.00 & 0.00 & 0.04 & 0.04 & 0.03 & 2.70 & 2.73 \\
\hline Muskogee & 0.00 & 75.03 & 75.03 & 0.79 & 0.00 & 0.79 & 0.00 & 9.68 & 9.68 \\
\hline Noble & 0.00 & 0.00 & 0.00 & 0.13 & 0.00 & 0.13 & 0.00 & 0.00 & 0.00 \\
\hline Nowata & 0.00 & 0.00 & 0.00 & 0.06 & 0.00 & 0.06 & 0.00 & 0.00 & 0.00 \\
\hline Okfuskee & 0.00 & 0.00 & 0.00 & 0.09 & 0.00 & 0.09 & 0.00 & 0.00 & 0.00 \\
\hline Oklahoma & 0.13 & 7.30 & 7.43 & 2.06 & 0.08 & 2.14 & 0.06 & 0.00 & 0.06 \\
\hline Okmulgee & 0.00 & 0.00 & 0.00 & 0.00 & 0.00 & 0.00 & 0.00 & 0.00 & 0.00 \\
\hline Osage & 0.00 & 0.00 & 0.00 & 0.57 & 0.50 & 1.07 & 0.41 & 0.13 & 0.54 \\
\hline Ottawa & 0.00 & 0.00 & 0.00 & 0.84 & 0.00 & 0.84 & 0.00 & 0.00 & 0.00 \\
\hline Pawnee & 0.00 & 11.89 & 11.89 & 0.40 & 0.00 & 0.40 & 0.00 & 0.00 & 0.00 \\
\hline Payne & 0.00 & 0.00 & 0.00 & 0.67 & 7.69 & 8.36 & 0.00 & 0.00 & 0.00 \\
\hline Pittsburg & 0.00 & 0.00 & 0.00 & 0.22 & 0.00 & 0.22 & 0.00 & 0.73 & 0.73 \\
\hline Pontotoc & 0.00 & 0.00 & 0.00 & 0.47 & 0.00 & 0.47 & 2.50 & 0.01 & 2.51 \\
\hline Pottawatomie & 0.00 & 0.00 & 0.00 & 1.77 & 0.00 & 1.77 & 0.07 & 0.00 & 0.07 \\
\hline Pushmataha & 0.00 & 0.00 & 0.00 & 0.13 & 0.23 & 0.36 & 0.00 & 0.00 & 0.00 \\
\hline Roger Mills & 0.00 & 0.00 & 0.00 & 0.06 & 0.11 & 0.17 & 0.00 & 0.00 & 0.00 \\
\hline Rogers & 0.00 & 12.28 & 12.28 & 0.47 & 2.49 & 2.96 & 0.00 & 0.00 & 0.00 \\
\hline Seminole & 0.00 & 13.83 & 13.83 & 0.34 & 0.02 & 0.36 & 0.00 & 0.00 & 0.00 \\
\hline Sequoyah & 0.00 & 0.00 & 0.00 & 0.07 & 0.00 & 0.07 & 0.00 & 1.25 & 1.25 \\
\hline Stephens & 0.00 & 0.00 & 0.00 & 0.56 & 0.38 & 0.94 & 0.00 & 0.00 & 0.00 \\
\hline Texas & 0.00 & 0.00 & 0.00 & 0.26 & 0.00 & 0.26 & 0.06 & 0.00 & 0.06 \\
\hline
\end{tabular}


Appendix 1. Estimated total freshwater withdrawals by county, use, and source in Oklahoma, 2005. —Continued

[Amounts are in million gallons per day. Totals may not add to totals because of independent rounding. Source: Oklahoma AWUDS database 2005 county aggregation. County aggregation may not match major river basin and principal aquifer aggregation due to independent aggregation]

\begin{tabular}{|c|c|c|c|c|c|c|c|c|c|}
\hline \multirow[b]{2}{*}{ County } & \multicolumn{3}{|c|}{$\begin{array}{c}\text { Thermoelectric-power } \\
\text { generation }\end{array}$} & \multicolumn{3}{|c|}{$\begin{array}{l}\text { Domestic and } \\
\text { commercial }\end{array}$} & \multicolumn{3}{|c|}{$\begin{array}{l}\text { Industrial and } \\
\text { mining }\end{array}$} \\
\hline & $\begin{array}{l}\text { Ground- } \\
\text { water }\end{array}$ & $\begin{array}{l}\text { Surface } \\
\text { water }\end{array}$ & Total & $\begin{array}{l}\text { Ground- } \\
\text { water }\end{array}$ & $\begin{array}{c}\text { Surface } \\
\text { water }\end{array}$ & Total & $\begin{array}{l}\text { Ground- } \\
\text { water }\end{array}$ & $\begin{array}{l}\text { Surface } \\
\text { water }\end{array}$ & Total \\
\hline Tillman & 0.00 & 0.00 & 0.00 & 0.06 & 0.00 & 0.06 & 0.00 & 0.00 & 0.00 \\
\hline Tulsa & 0.00 & 16.72 & 16.72 & 0.76 & 0.18 & 0.94 & 0.16 & 0.00 & 0.16 \\
\hline Wagoner & 0.00 & 0.00 & 0.00 & 0.00 & 0.03 & 0.03 & 0.00 & 0.00 & 0.00 \\
\hline Washington & 0.00 & 0.00 & 0.00 & 0.00 & 0.00 & 0.00 & 0.00 & 0.00 & 0.00 \\
\hline Washita & 0.00 & 0.00 & 0.00 & 0.19 & 0.08 & 0.27 & 0.00 & 0.00 & 0.00 \\
\hline Woods & 0.00 & 0.00 & 0.00 & 0.10 & 0.00 & 0.10 & 0.00 & 0.00 & 0.00 \\
\hline Woodward & 0.71 & 0.00 & 0.71 & 0.30 & 0.03 & 0.33 & 0.28 & 0.00 & 0.28 \\
\hline Totals & 1.25 & 162.98 & 164.23 & 29.60 & 16.57 & 46.17 & 9.05 & 17.72 & 26.77 \\
\hline
\end{tabular}


Appendix 1. Estimated total freshwater withdrawals by county, use, and source in Oklahoma, 2005. -- Continued

[Freshwater amounts are in million gallons per day. Population values are in thousands. Totals may not add to totals because of independent rounding] Source: Oklahoma AWUDS database 2005 county aggregation. County aggregation may not match major river basin and principal aquifer aggregation due to independent aggregation]

\begin{tabular}{|c|c|c|c|c|c|c|c|}
\hline \multirow{3}{*}{ County } & \multirow{2}{*}{\multicolumn{3}{|c|}{ Total }} & \multicolumn{4}{|c|}{ Population } \\
\hline & & & & \multicolumn{2}{|c|}{ Public supply } & \multirow{2}{*}{$\begin{array}{c}\begin{array}{c}\text { Self- } \\
\text { supplied }\end{array} \\
\text { Ground- } \\
\text { water }\end{array}$} & \multirow[b]{2}{*}{ Total } \\
\hline & $\begin{array}{c}\text { Ground- } \\
\text { water }\end{array}$ & $\begin{array}{c}\text { Surface } \\
\text { water }\end{array}$ & Total & $\begin{array}{c}\text { Ground- } \\
\text { water }\end{array}$ & $\begin{array}{c}\text { Surface } \\
\text { water }\end{array}$ & & \\
\hline Adair & 1.02 & 8.58 & 9.60 & 0.03 & 12.79 & 9.14 & 21.96 \\
\hline Alfalfa & 3.83 & 2.64 & 6.47 & 4.87 & 0.00 & 0.86 & 5.73 \\
\hline Atoka & 0.55 & 55.90 & 56.45 & 1.06 & 10.26 & 3.03 & 14.34 \\
\hline Beaver & 25.98 & 0.08 & 26.06 & 2.78 & 0.00 & 2.62 & 5.40 \\
\hline Beckham & 7.86 & 1.24 & 9.10 & 16.83 & 0.00 & 1.98 & 18.81 \\
\hline Blaine & 4.62 & 3.88 & 8.50 & 11.74 & 0.00 & 1.13 & 12.87 \\
\hline Bryan & 2.61 & 17.60 & 20.21 & 6.95 & 28.01 & 2.78 & 37.73 \\
\hline Caddo & 29.10 & 21.96 & 51.06 & 11.82 & 6.55 & 11.73 & 30.09 \\
\hline Canadian & 6.27 & 1.97 & 8.24 & 63.09 & 35.36 & 0.00 & 98.45 \\
\hline Carter & 2.06 & 16.93 & 18.99 & 8.02 & 38.79 & 0.22 & 47.03 \\
\hline Cherokee & 0.78 & 10.21 & 10.99 & 0.20 & 36.79 & 7.43 & 44.42 \\
\hline Choctaw & 1.20 & 10.74 & 11.94 & 3.70 & 6.93 & 4.70 & 15.32 \\
\hline Cimarron & 50.86 & 0.25 & 51.11 & 1.68 & 0.00 & 1.12 & 2.80 \\
\hline Cleveland & 12.71 & 22.20 & 34.91 & 61.90 & 149.66 & 12.67 & 224.23 \\
\hline Coal & 0.28 & 1.78 & 2.06 & 0.69 & 3.47 & 1.57 & 5.74 \\
\hline Comanche & 3.93 & 19.55 & 23.48 & 12.94 & 95.50 & 2.19 & 110.63 \\
\hline Cotton & 0.77 & 1.96 & 2.73 & 2.38 & 4.14 & 0.00 & 6.52 \\
\hline Craig & 0.58 & 2.03 & 2.61 & 2.19 & 12.07 & 0.80 & 15.06 \\
\hline Creek & 2.06 & 5.94 & 8.00 & 11.55 & 50.08 & 7.05 & 68.68 \\
\hline Custer & 7.38 & 4.11 & 11.49 & 12.12 & 9.85 & 3.32 & 25.28 \\
\hline Delaware & 1.82 & 4.14 & 5.96 & 4.61 & 23.10 & 11.50 & 39.21 \\
\hline Dewey & 3.54 & 1.36 & 4.90 & 3.47 & 0.00 & 1.07 & 4.54 \\
\hline Ellis & 15.49 & 0.16 & 15.65 & 2.58 & 0.00 & 1.38 & 3.96 \\
\hline Garfield & 4.13 & 2.26 & 6.39 & 55.43 & 0.00 & 1.46 & 56.89 \\
\hline Garvin & 1.70 & 4.32 & 6.02 & 9.12 & 13.91 & 4.15 & 27.18 \\
\hline Grady & 5.31 & 9.62 & 14.93 & 14.19 & 19.44 & 15.74 & 49.37 \\
\hline Grant & 1.98 & 1.68 & 3.66 & 4.15 & 0.00 & 0.65 & 4.80 \\
\hline Greer & 5.08 & 1.16 & 6.24 & 5.87 & 0.00 & 0.00 & 5.87 \\
\hline Harmon & 26.03 & 0.67 & 26.70 & 3.05 & 0.00 & 0.00 & 3.05 \\
\hline Harper & 7.92 & 7.98 & 15.90 & 2.38 & 0.00 & 0.96 & 3.34 \\
\hline Haskell & 0.68 & 4.81 & 5.49 & 0.00 & 6.81 & 5.28 & 12.09 \\
\hline Hughes & 1.72 & 6.76 & 8.48 & 1.43 & 11.53 & 0.94 & 13.90 \\
\hline Jackson & 9.68 & 66.55 & 76.23 & 2.70 & 22.56 & 1.08 & 26.34 \\
\hline
\end{tabular}


Appendix 1. Estimated total freshwater withdrawals by county, use, and source in Oklahoma, 2005. -- Continued

[Freshwater amounts are in million gallons per day. Population values are in thousands. Totals may not add to totals because of independent rounding] Source: Oklahoma AWUDS database 2005 county aggregation. County aggregation may not match major river basin and principal aquifer aggregation due to independent aggregation]

\begin{tabular}{|c|c|c|c|c|c|c|c|}
\hline \multirow{3}{*}{ County } & \multirow{2}{*}{\multicolumn{3}{|c|}{ Total }} & \multicolumn{4}{|c|}{ Population } \\
\hline & & & & \multicolumn{2}{|c|}{ Public supply } & \multirow{2}{*}{$\begin{array}{c}\begin{array}{c}\text { Self- } \\
\text { supplied }\end{array} \\
\begin{array}{c}\text { Ground- } \\
\text { water }\end{array}\end{array}$} & \multirow[b]{2}{*}{ Total } \\
\hline & $\begin{array}{c}\text { Ground- } \\
\text { water }\end{array}$ & $\begin{array}{c}\text { Surface } \\
\text { water }\end{array}$ & Total & $\begin{array}{c}\text { Ground- } \\
\text { water }\end{array}$ & $\begin{array}{c}\text { Surface } \\
\text { water }\end{array}$ & & \\
\hline Jefferson & 0.86 & 6.20 & 7.06 & 1.61 & 4.70 & 0.14 & 6.45 \\
\hline Johnston & 1.97 & 14.22 & 16.19 & 6.40 & 3.78 & 0.11 & 10.29 \\
\hline Kay & 11.69 & 14.71 & 26.40 & 26.85 & 17.11 & 2.24 & 46.20 \\
\hline Kingfisher & 6.92 & 3.35 & 10.27 & 10.23 & 0.00 & 4.01 & 14.24 \\
\hline Kiowa & 2.86 & 11.66 & 14.52 & 4.23 & 5.66 & 0.00 & 9.89 \\
\hline Latimer & 0.20 & 2.55 & 2.75 & 0.00 & 9.29 & 1.32 & 10.61 \\
\hline Le Flore & 2.33 & 19.43 & 21.76 & 0.70 & 42.35 & 6.36 & 49.40 \\
\hline Lincoln & 2.15 & 3.57 & 5.72 & 4.74 & 9.95 & 17.65 & 32.35 \\
\hline Logan & 2.20 & 3.84 & 6.04 & 10.20 & 14.96 & 11.26 & 36.42 \\
\hline Love & 1.41 & 2.35 & 3.76 & 5.35 & 3.49 & 0.31 & 9.15 \\
\hline McClain & 3.95 & 1.93 & 5.88 & 17.02 & 5.55 & 7.43 & 30.00 \\
\hline McCurtain & 0.88 & 8.97 & 9.85 & 0.00 & 26.40 & 7.49 & 33.88 \\
\hline McIntosh & 0.35 & 4.59 & 4.94 & 1.43 & 18.39 & 0.00 & 19.82 \\
\hline Major & 18.73 & 0.61 & 19.34 & 5.22 & 0.00 & 2.09 & 7.31 \\
\hline Marshall & 2.43 & 4.81 & 7.24 & 3.88 & 9.83 & 0.65 & 14.36 \\
\hline Mayes & 0.24 & 106.95 & 107.19 & 0.63 & 38.79 & 0.00 & 39.42 \\
\hline Murray & 2.15 & 18.28 & 20.43 & 9.95 & 2.86 & 0.00 & 12.81 \\
\hline Muskogee & 4.11 & 106.13 & 110.24 & 2.81 & 61.02 & 6.85 & 70.68 \\
\hline Noble & 0.32 & 1.93 & 2.25 & 1.87 & 7.80 & 1.52 & 11.20 \\
\hline Nowata & 0.19 & 2.06 & 2.25 & 0.00 & 10.12 & 0.69 & 10.81 \\
\hline Okfuskee & 0.65 & 2.24 & 2.89 & 1.88 & 8.43 & 1.10 & 11.41 \\
\hline Oklahoma & 22.08 & 84.58 & 106.66 & 122.23 & 547.93 & 14.04 & 684.20 \\
\hline Okmulgee & 0.09 & 16.04 & 16.13 & 1.46 & 38.20 & 0.00 & 39.67 \\
\hline Osage & 1.54 & 18.64 & 20.18 & 4.64 & 33.93 & 6.76 & 45.33 \\
\hline Ottawa & 4.30 & 1.78 & 6.08 & 24.71 & 1.10 & 6.99 & 32.80 \\
\hline Pawnee & 0.82 & 15.14 & 15.96 & 3.68 & 8.49 & 4.65 & 16.82 \\
\hline Payne & 2.68 & 10.18 & 12.86 & 13.02 & 52.48 & 7.92 & 73.43 \\
\hline Pittsburg & 0.48 & 11.39 & 11.87 & 0.00 & 44.55 & 0.00 & 44.55 \\
\hline Pontotoc & 3.75 & 8.09 & 11.84 & 6.28 & 23.44 & 5.49 & 35.21 \\
\hline Pottawatomie & 2.62 & 6.01 & 8.63 & 9.94 & 37.32 & 20.83 & 68.08 \\
\hline Pushmataha & 0.28 & 2.02 & 2.30 & 0.00 & 10.12 & 1.54 & 11.66 \\
\hline Roger Mills & 5.89 & 2.73 & 8.62 & 1.90 & 0.73 & 0.68 & 3.31 \\
\hline Rogers & 0.66 & 83.55 & 84.21 & 0.00 & 74.93 & 5.58 & 80.51 \\
\hline
\end{tabular}


Appendix 1. Estimated total freshwater withdrawals by county, use, and source in Oklahoma, 2005.

\section{-- Continued}

[Freshwater amounts are in million gallons per day. Population values are in thousands. Totals may not add to totals because of independent rounding] Source: Oklahoma AWUDS database 2005 county aggregation. County aggregation may not match major river basin and principal aquifer aggregation due to independent aggregation]

\begin{tabular}{|c|c|c|c|c|c|c|c|}
\hline \multirow{3}{*}{ County } & \multirow{2}{*}{\multicolumn{3}{|c|}{ Total }} & \multicolumn{4}{|c|}{ Population } \\
\hline & & & & \multicolumn{2}{|c|}{ Public supply } & \multirow{2}{*}{$\begin{array}{c}\text { Self- } \\
\text { supplied } \\
\text { Ground- } \\
\text { water }\end{array}$} & \multirow[b]{2}{*}{ Total } \\
\hline & $\begin{array}{c}\text { Ground- } \\
\text { water }\end{array}$ & $\begin{array}{c}\text { Surface } \\
\text { water }\end{array}$ & Total & $\begin{array}{c}\text { Ground- } \\
\text { water }\end{array}$ & $\begin{array}{c}\text { Surface } \\
\text { water }\end{array}$ & & \\
\hline Seminole & 2.13 & 16.03 & 18.16 & 16.00 & 4.66 & 3.98 & 24.64 \\
\hline Sequoyah & 0.92 & 10.63 & 11.55 & 0.00 & 39.95 & 0.82 & 40.77 \\
\hline Stephens & 1.88 & 3.43 & 5.31 & 10.10 & 26.20 & 6.62 & 42.93 \\
\hline Texas & 166.93 & 0.28 & 167.21 & 17.53 & 0.00 & 2.60 & 20.13 \\
\hline Tillman & 8.14 & 1.10 & 9.24 & 1.70 & 6.16 & 0.67 & 8.53 \\
\hline Tulsa & 2.05 & 17.73 & 19.78 & 0.00 & 561.68 & 8.94 & 570.62 \\
\hline Wagoner & 0.41 & 9.23 & 9.64 & 0.00 & 64.19 & 0.00 & 64.19 \\
\hline Washington & 0.09 & 4.72 & 4.81 & 0.00 & 49.00 & 0.00 & 49.00 \\
\hline Washita & 4.62 & 4.12 & 8.74 & 8.12 & 1.14 & 2.20 & 11.46 \\
\hline Woods & 5.76 & 0.02 & 5.78 & 7.38 & 0.00 & 1.11 & 8.49 \\
\hline Woodward & 15.64 & 0.28 & 15.92 & 15.51 & 0.00 & 3.50 & 19.01 \\
\hline Totals & 569.88 & 989.12 & $1,559.00$ & 724.72 & $2,524.28$ & 294.69 & $3,543.67$ \\
\hline
\end{tabular}




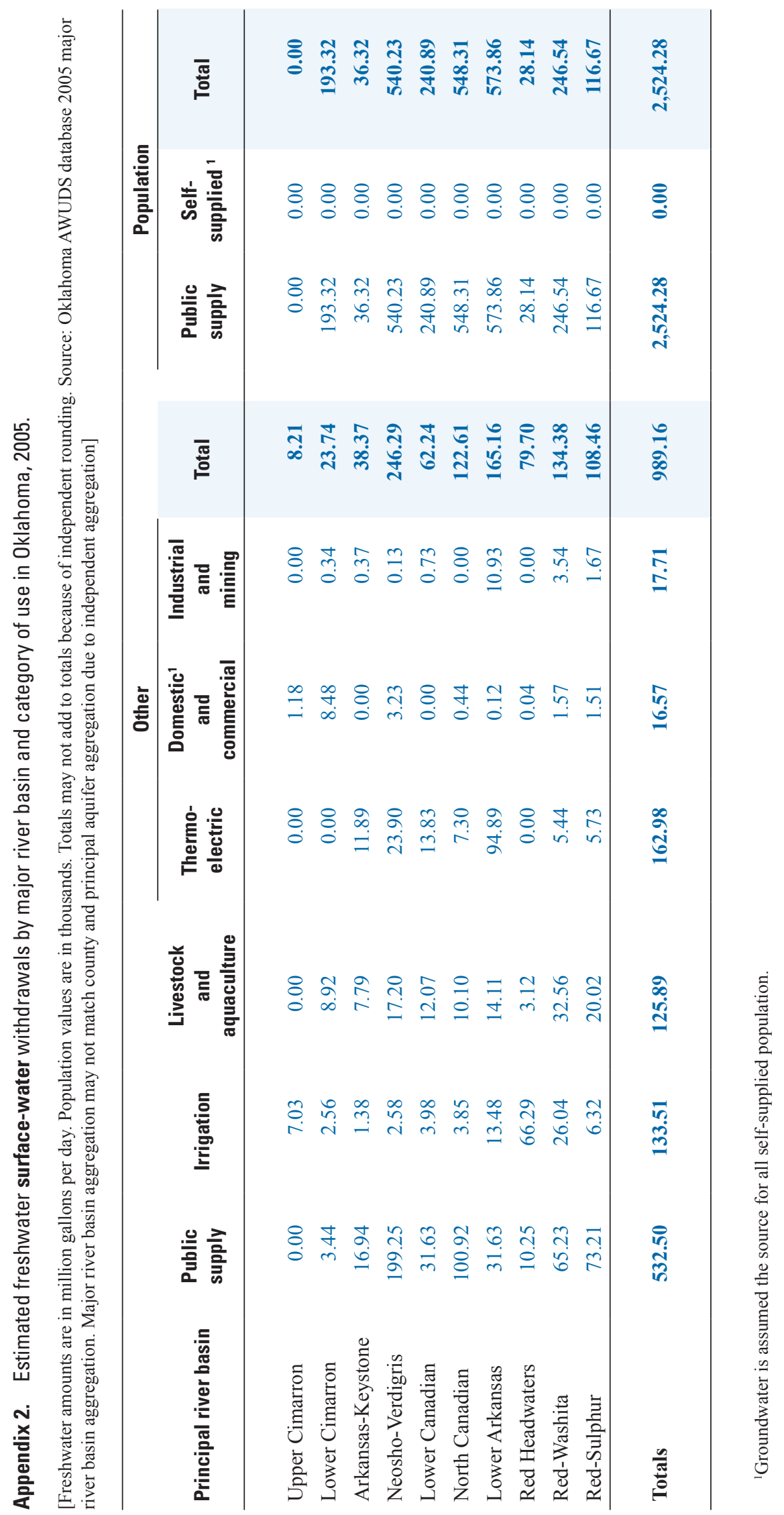




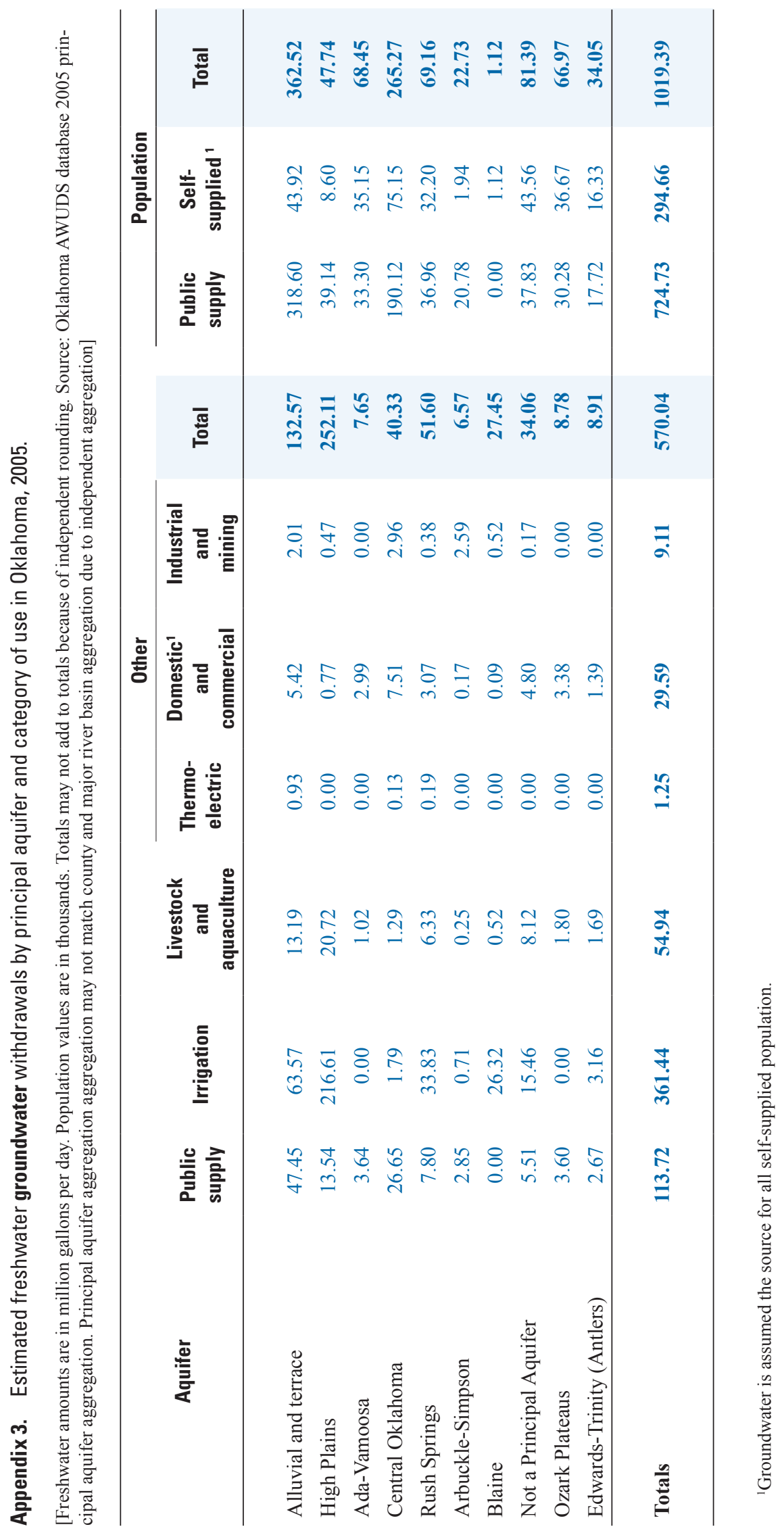




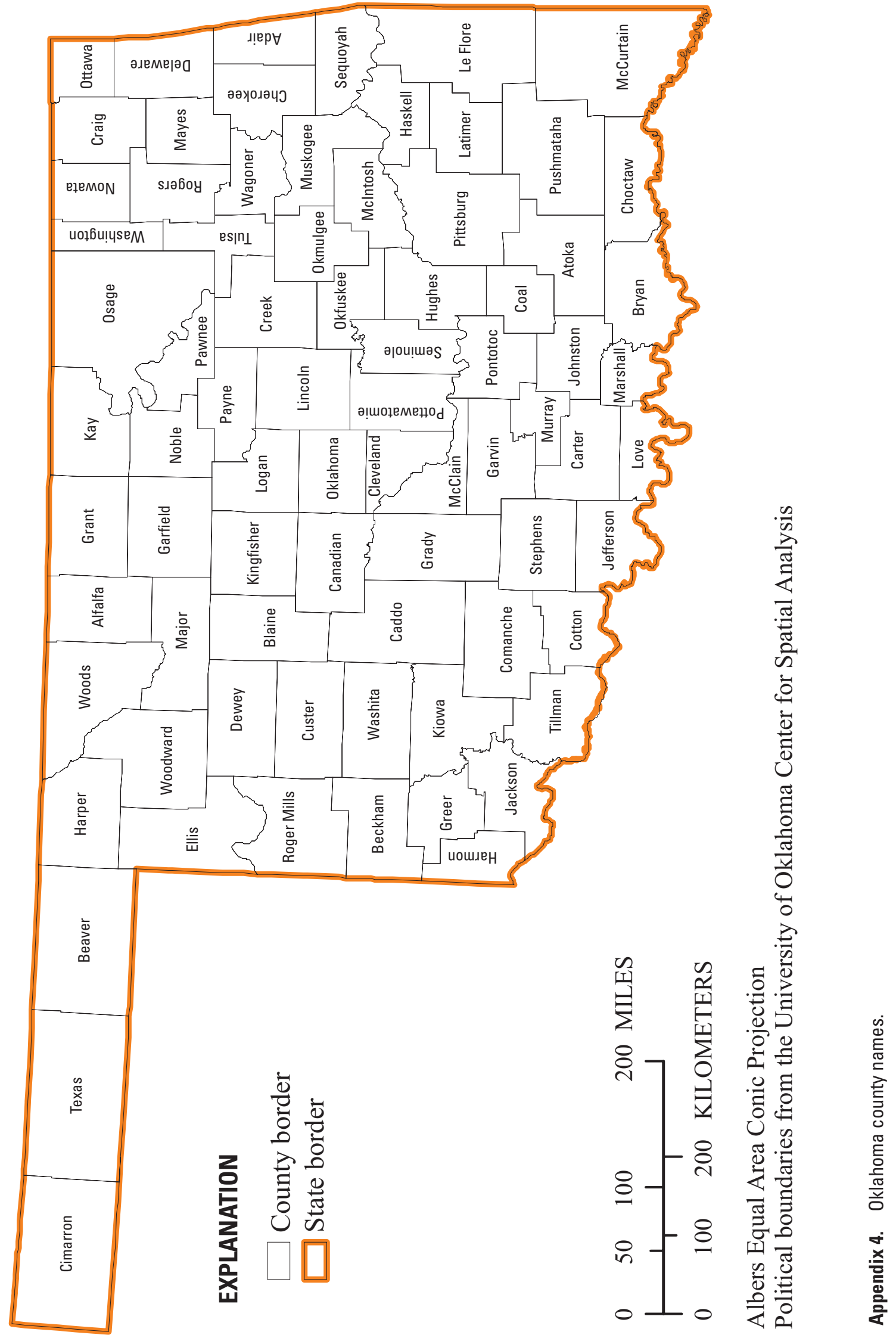


Publishing support provided by Lafayette Publishing Service Center

For more information concerning this publication, contact

Director, USGS Oklahoma Water Science Center 202 NW 66th St., Bldg. 7

Oklahoma City, OK 73116

(405) 810-4400

Or visit the Oklahoma Water Science Center web site at: http://ok.water.usgs.gov 


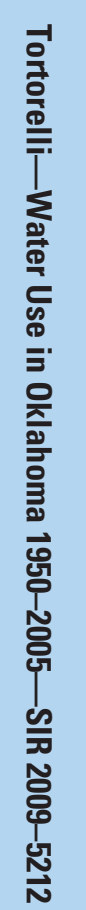

8 Printed on recycled paper 